UNIVERSIDADE DE SÃO PAULO

ESCOLA DE ARTES, CIÊNCIAS E HUMANIDADES

PROGRAMA DE PÓS-GRADUAÇÃO EM MUDANÇA SOCIAL E

PARTICIPAÇÃ̃ POLÍTICA

FELIPE SOUSA NEVES ANDRADE

ESTUDO DO IMPACTO POTENCIAL DAS MUDANÇAS CLIMÁTICAS NA BIODETERIORAÇÃO DE ESTRUTURAS DE MADEIRAS NO PATRIMÔNIO CULTURAL EDIFICADO DO VALE HISTÓRICO PAULISTA 
Felipe Sousa Neves Andrade

\title{
ESTUDO DO IMPACTO POTENCIAL DAS MUDANÇAS CLIMÁTICAS NA BIODETERIORAÇÃO DE ESTRUTURAS DE MADEIRAS NO PATRIMÔNIO CULTURAL EDIFICADO DO VALE HISTÓRICO PAULISTA
}

\author{
Versão Corrigida
}

Dissertação apresentada à Escola de Artes, Ciências e Humanidades da Universidade de São Paulo para obtenção do título em Mestre em Ciências pelo Programa de Pós Graduação em Mudança Social e Participação Política.

Versão corrigida contendo as alterações solicitadas pela comissão julgadora em 14 de março de 2016. A versão original encontra-se em acervo reservado na Biblioteca da EACH/USP e na Biblioteca Digital de Teses e Dissertações da USP (BDTD), de acordo com a Resolução CoPGr 6018, de 13 de outubro de 2011.

Orientador: Prof. Dr. Andrea Cavicchioli Co-Orientadora: Dra. Alejandra Teresa Fazio 
Autorizo a reprodução e divulgação total ou parcial deste trabalho, por qualquer meio convencional ou eletrônico, para fins de estudo e pesquisa, desde que citada a fonte.

CATALOGAÇÃO-NA-PUBLICAÇÃO

(Universidade de São Paulo. Escola de Artes, Ciências e Humanidades. Biblioteca)

Andrade, Felipe Sousa Neves

Estudo do impacto potencial das mudanças climáticas na biodeterioração de estruturas de madeiras no patrimônio cultural edificado do Vale Histórico Paulista / Felipe Souza Neves Andrade ; orientadora, Andrea Cavicchioli ; co-orientadora, Alejandra Tereza Fazio.

- São Paulo, 2016

$121 \mathrm{f}$. : il

Dissertação (Mestrado em Ciências) - Programa de Pós-

Graduação em Mudança Social e Participação Política, Escola de Artes, Ciências e Humanidades, Universidade de São Paulo Versão corrigida

1. Patrimônio Histórico. 2. Patrimônio Arquitetônico -

Deterioração (SP). 3. Mudança Climática. 4. Fungos de madeira 5. Vale do Paraíba (SP). I. Cavicchioli, Andrea, orient. II. Fazio, Alejandra Tereza, co-orient. III. Título

CDD 22.ed. -306.53636 
Nome: ANDRADE, Felipe Sousa Neves

Estudo do impacto potencial das mudanças climáticas na biodeterioração de estruturas de madeiras no patrimônio cultural edificado do Vale Histórico Paulista

Dissertação apresentada à Escola de Artes, Ciências e Humanidades da Universidade de São Paulo para obtenção do título de Mestre em Ciências do Programa de Pós-Graduação em Mudança Social e Participação Política

Aprovado em:

\section{Banca Examinadora}

Prof. Dr.

Instituição:

Julgamento:

Assinatura:

Prof. Dr.

Instituição:

Julgamento:

Assinatura:

Prof. Dr.

Instituição:

Julgamento:

Assinatura: 


\section{RESUMO}

ANDRADE, F. S. N. Estudo do impacto potencial das mudanças climáticas na biodeterioração de estruturas de madeiras no patrimônio cultural edificado do Vale Histórico Paulista. 2016. Número total de f. 121. Dissertação (Mestrado em Ciências) Escola de Artes, Ciências e Humanidades, Universidade de São Paulo, São Paulo, 2016.

O presente trabalho busca contribuir com as pesquisas acerca das perspectivas de impacto das mudanças climáticas no patrimônio cultural do Vale Histórico de São Paulo, com enfoque na ação de fungos nas estruturas de madeira das edificações históricas. Diversos estudos têm sido realizados na Europa a respeito desse tema, mas no Brasil trabalhos desse tipo não são numerosos. A revisão da literatura a respeito das mudanças climáticas indica aumentos na temperatura do ar, alterações nos regimes de precipitação e em diversas outras variáveis climáticas em todo o planeta. Foram coletados dados meteorológicos da região estudada e dados de monitoramento do microclima do interior de algumas edificações. Também foram obtidos dados de simulação a respeito do clima nos próximos 100 anos na região. Podendo-se, assim, obter um cenário de possibilidades de mudanças no clima e no microclima das edificações. Investigou-se a presença de fungos degradadores de lignocelulose nas edificações em estudo e os impactos das variações de temperatura no desenvolvimento desse tipo de fungo. As conclusões do trabalho indicam que as mudanças no clima da região podem aumentar os riscos de deterioração dos prédios históricos da região estudada.

Palavras-chave: Vale Histórico Paulista, Mudanças Climáticas, Edificações Históricas, Fungos, Deterioração. 


\begin{abstract}
ANDRADE, F. S. N. Study of the potential impact of climate change on wood structures decay in the built cultural heritage of Vale Histórico Paulista. 2016. Number of pages p. 121. Dissertation (Master of Science) - School of Arts, Sciences and Humanities, University of São Paulo, São Paulo, 2016.

This study aims to contribute to investigate the impact projections for of climate change on cultural heritage of the Vale Histórico Paulista, focusing on the action of fungi in the wood structures of historic buildings. Several studies have been conducted in Europe on this subject, but in Brazil works of this nature are not numerous. A review of the literature on climate change indicates overall increases in air temperature, changes in precipitation regimes and several other climatic alterations across the planet. Meteorological data from the study area and microclimate monitoring data from the indoor microclimate of some buildings were collected. Climate simulation data concerned the next 100 years in the region were also obtained, thus resulting in a scenario of climate and indoor microclimate changes. Experimental analysis on the presence of lignocellulose-degrading fungi on cultural heritage materials were carried out. The findings of the study indicate that changes in the climate of the region can increase the risk of biodeterioration of historic buildings.
\end{abstract}

Keywords: Vale Histórico Paulista. Climate change. Historic buildings. Fungi. Deterioration. 


\section{RESUMEN}

ANDRADE F. S. N. Estudio del impacto potencial del cambio climático en la biodeterioracíon de las estructuras de madera del patrimonio cultural construido en Vale Histórico Paulista. 2016. Número total de f. 121. Dissertación (Mestrado en Ciencia) Escola de Artes, Ciências e Humanidades, Universidade de São Paulo, São Paulo, 2016.

En este trabajo se pretende contribuir a la investigación sobre las perspectivas de impacto del cambio climático sobre el patrimonio cultural del Vale Historico Paulista, centrándose en la acción de los hongos en las estructuras de madera de los edificios históricos. Varios estudios se han realizado en Europa sobre este tema, pero en Brasil estos puestos de trabajo no son numerosos. Una revisión de la literatura sobre el cambio climático indican aumentos en la temperatura del aire, cambios en los regímenes de precipitación y otras variables climáticas en todo el planeta. Los datos meteorológicos fueron recolectados de la zona de estudio y seguimiento de los datos de microclima interiores de algunos edificios. También se obtuvieron alrededor de los datos de simulación del clima en los próximos 100 años en la región. Ser capaz de obtener de este modo un contexto de cambio de posibilidades en el clima y el microclima de los edificios. Hemos investigado la presencia de hongos degradantes lignocelulosa en edificios en estudio y los efectos de las variaciones de temperatura en el desarrollo de este tipo de hongo. Las conclusiones del estudio indican que los cambios en el clima de la zona puede aumentar el riesgo de deterioro de los edificios históricos de la región estudiada.

Palabras clave: Vale Histórico Paulista. Cambio Climatico. Edificios históricos. Hongos. Deterioración. 


\section{LISTA DE FIGURAS}

Figura 1. Mapa da localização do Vale Histórico. Fonte: Adaptado de FAZIO et al. (2015)

Figura 2. Paisagens urbanas e rurais no Vale Histórico Paulista. Fazenda Catadupa, São José do Barreiro (A); Fazenda Resgate, Bananal (B); Solar Aguiar Valim, Bananal (C); Solar, São José do Barreiro (D). Fonte: acervo pessoal do orientador.

Figura 3. Exemplos de casos de deterioração estrutural nas edificações históricas do Vale Histórico Paulista. Casarão, São José do Barreiro (A); Tulha na Fazenda da Barra, São José do Barreiro (B); Interior do Solar Aguiar Valim, Bananal (C); Fazenda Casa Grande, Bananal (D). Fonte: acervo pessoal do orientador.

Figura 4. Mapa do Brasil com os domínios morfoclimáticos. Em verde claro, os "mares de morro", que engloba o Vale do Paraíba. Fonte: http://docplayer.com.br/2314095-Dominiosmorfoclimaticos-brasileiros.html

Figura 5. Classes climáticas da classificação de Köpper adaptada por Alvares et al. (2013). Af, Tropical sem estação seca; Aw, tropicalcom inverno seco; Cwa, Subtropical úmido com inverno seco e verão quente; Cwb, Subtropical úmido com inverno seco e verão temperado; Cfa, Subtropical úmido com verão quente e sem estação seca; e; $\mathbf{C f b}$, Subtropical úmido com verão temperado e sem estação seca. Fonte: ALVARES et al. (2013).

Figura 6. Comparação entre temperaturas máximas mensais $\left({ }^{\circ} \mathrm{C}\right)$ observadas (estações de Taubaté e São Luís do Paraitinga - SLP) e simuladas para clima atual (ERA, HAD6090 e ECH6090) e futuro (HAD7000 e ECH7000). Fonte: YNOUE, et al. (2014).

Figura 7. Comparação entre temperaturas mínimas mensais $\left({ }^{\circ} \mathrm{C}\right)$ observadas (estações de Taubaté e São Luís do Paraitinga) e simuladas para clima atual (ERA, HAD6090 e ECH6090) e futuro (HAD7000 e ECH7000). Fonte: YNOUE et al. (2014).

Figura 8. Comparação entre UR médias mensais observadas (estações de Taubaté e São Luís do Paraitinga - SLP) e simuladas para clima atual e futuro (ERA-Interim, HadCM3 e ECHAM5). Fonte: YNOUE et al. (2014).

Figura 9. Mapa do aumento do risco desgaste material (recession) de superfícies de materiais a base de carbonatos (p. ex. mármore) frente a mudanças no clima projetadas com base no cenário A2 por meio de projeções para o clima de 2079-2099 realizadas com o modelo HadRM3. Fonte: BONAZZA et al. (2009).

Figura 10. Modelo estrutura celular da madeira. $\mathrm{LM}=$ lamela média, $\mathrm{P}=$ parede primária, $\mathrm{S} 1$ = camada 1 da parede secundária, S2 = camada 2 da parede secundária, S3 = camada 3 da parede secundária ou parede terciária segundo alguns autores, $\mathrm{W}=$ camada verrugosa (warts). Fonte: KLOCK et al. (2005).

Figura 11. Imagem de madeira de pinho com podridão castanha. Fonte: WIEDENHOEFT; MILLER (2005).

Figura 12. Diagrama que mostra a localização das regiões do rDNA objetivadas na identificação de fungos e a lista dos principais primers(ver definição no texto) desenvolvidos para essa finalidade. Fonte: MARTIN; RYGIEWICZ (2005). 
Figura 13. Esquema mostrando o processo de manutenção dos fungos pela técnica de cultivo em "bico de flauta".

Figura 14. Fazenda São Francisco na visão frontal (lado NW) e em imagem do google Earth correspondente a altura de $200 \mathrm{~m}$ acima da fazenda. Na planta, estão indicados os pontos de instalação dos dataloggers para as medidas microclimáticas: Sótão (1), quarto de dormir no nível principal da casa correspondente às janelas superiores da fachada (2), corredor no nível principal da casa correspondente às janelas superiores da fachada (3), salas no piso inferior (lojinha e museu) correspondentes aos vãos inferiores da fachada (4 e 5). Fonte: acervo pessoal do orientador.

Figura 15. Fazenda São Miguel na visão frontal (lado NW) e em imagem do google Earth correspondente a altura de $200 \mathrm{~m}$ acima da fazenda. Na planta, estão indicados os pontos de instalação dos dataloggers para as medidas microclimáticas: Sótão (1), salas no nível principal da casa correspondente às janelas superiores da fachada (2-4), sala no piso inferior correspondentes a vão inferior na fachada (5). Fonte: acervo pessoal do orientador.

Figura 16. Fazenda Catadupa na visão frontal (lado NW) e em imagem do google Earth correspondente a altura de $200 \mathrm{~m}$ acima da fazenda. Na planta, estão indicados os pontos de instalação dos dataloggers para as medidas microclimáticas: Sótão (1), sala no nível principal da casa correspondente às janelas superiores da fachada (2) e senzala doméstica correspondente a nível intermediária entre as duas fileiras de janelas da fachada (3). Fonte: acervo pessoal do orientador.

Figura 17. Fazenda Vargem Grande na visão frontal (lado NW) e em imagem do google Earth correspondente a altura de $200 \mathrm{~m}$ acima da fazenda. Na planta, estão indicados os pontos de instalação dos dataloggers para as medidas microclimáticas: Sótão (1), sala no nível principal da casa correspondente às janelas superiores da fachada (2) e sala no nível inferior correspondente fileira inferior de janelas da fachada (3). Fonte: acervo pessoal do orientador.

Figura 18. Exemplos de ensaio de atividade celulolítica. (A) Placa controle sem corante. (B) Placa controle sem corante, após lavagem com solução $1 \mathrm{M}$ de $\mathrm{NaCl}$. (C) Cepa 59. Placa antes da aplicação do vermelho de congo. (D) Cepa 59. Resultado positivo. Foro do meio de cultura com corante após lavagem. Os colchetes indicam os diâmetros do halo e da colônia que serviram para determinar o I.e.. (E) Cepa75. Antes da aplicação do vermelho de congo. (F) Cepa 75. Placa com corante vermelho de congo, após lavagem. Resultado negativo. Observase que não houve formação de halo.

Figura 19. Cepa 62, Spegazzinia tessarthra. (A) Foto da colônia em placa de petri. (B) Imagem de microscópio: em destaque conídios do tipo septado. (C) Imagem de microscópio: em destaque conídios lisos com quatro células.

Figura 20. Gel para avaliação do DNA amplificado usando-se os primers ITS e NS, respectivamente. Padrão de massas moleculares 100 bp Ladder.

Figura 21. Gel para avaliação do DNA amplificado usando-se os primers ITS e NS, respectivamente. Padrão de massas moleculares 100 bp Ladder. 
Figura 23. Séries temporais das diferenças entre a razão de mistura do vapor $\left(\mathrm{g} \mathrm{kg}^{-1}\right)$ nos locais indoor e no ambiente outdoor na Fazenda São Francisco no período de 1/1/2015 a $31 / 12 / 2015$.

Figura 24. Detalhamento da variação das temperaturas médias diárias medidas em cinco locais do casarão em dois períodos climaticamente distintos: janeiro (ESQ.) e agosto (DIR.) na fazenda São Francisco. Nas plotagem, foram usados valores diferenciais frente às temperaturas médias diárias externas.

Figura 25. Detalhamento da variação das temperaturas horárias medidas em cinco locais do casarão em dois períodos climaticamente distintos: janeiro (ESQ.) e agosto (DIR.) na fazenda São Francisco. Nas plotagem, foram usados valores diferenciais frente às temperaturas médias diárias externas.

Figura 26. Séries temporais das diferenças entre a razão de mistura do vapor $\left(\mathrm{g} \mathrm{kg}^{-1}\right)$ nos locais indoor e no ambiente outdoor na Fazenda São Miguel no período de 1/1/2015 a $31 / 12 / 2015$.

Figura 27. Detalhamento da variação das temperaturas médias diárias medidas em cinco locais do casarão em dois períodos climaticamente distintos: janeiro (ESQ.) e agosto (DIR.) na fazenda São Miguel. Nas plotagem, foram usados valores diferenciais frente às temperaturas médias diárias externas.

Figura 28. Detalhamento da variação das temperaturas horárias medidas em cinco locais do casarão em dois períodos climaticamente distintos: janeiro (ESQ.) e agosto (DIR.) na fazenda São Miguel. Nas plotagem, foram usados valores diferenciais frente às temperaturas médias diárias externas.

Figura 29. Séries temporais das diferenças entre a razão de mistura do vapor $\left(\mathrm{g} \mathrm{kg}^{-1}\right)$ nos locais indoor e no ambiente outdoor na Fazenda Vargem Grande no período de 1/6/2013 a $31 / 5 / 2014$.

Figura 30. Detalhamento da variação das temperaturas médias diárias medidas em três locais do casarão em dois períodos climaticamente distintos: fevereiro (ESQ.) e agosto (DIR.) na Fazenda Vargem Grande. Nas plotagem, foram usados valores diferenciais frente às temperaturas médias diárias externas.

Figura 31. Detalhamento da variação das temperaturas horárias medidas em três locais do casarão em dois períodos climaticamente distintos: janeiro (ESQ.) e agosto (DIR.) na fazenda Vargem Grande. Nas plotagem, foram usados valores diferenciais frente às temperaturas médias diárias externas.

Figura 32. Séries temporais das diferenças entre a razão de mistura do vapor $\left(\mathrm{g} \mathrm{kg}^{-1}\right)$ nos locais indoor e no ambiente outdoor na Fazenda Catadupa no período de 1/6/2013 a $31 / 5 / 2014$.

Figura 33. Detalhamento da variação das temperaturas médias diárias medidas em três locais do casarão em dois períodos climaticamente distintos: fevereiro (ESQ.) e agosto (DIR.) na Fazenda Catadupa. Nas plotagem, foram usados valores diferenciais frente às temperaturas médias diárias externas. 
Figura 34. Detalhamento da variação das temperaturas horárias medidas em três locais do casarão em dois períodos climaticamente distintos: janeiro (ESQ.) e agosto (DIR.) na fazenda Catadupa. Nas plotagem, foram usados valores diferenciais frente às temperaturas médias diárias externas.

Figura 35. Crescimento das cepas em temperaturas médias de inverno e verão, presentes e previstas para o final do século XXI. (A) cepa 37 - crescimento a temperaturas médias de verão presente $\left(26^{\circ} \mathrm{C}\right)$ e futura $\left(29^{\circ} \mathrm{C}\right)$; (B) cepa 37 - crescimento a temperaturas médias de inverno presente $\left(20^{\circ} \mathrm{C}\right)$ e futura $\left(24^{\circ} \mathrm{C}\right)$; (C) cepa 47 - crescimento a temperaturas médias de verão presente e futura; (D) cepa 47-crescimento a temperaturas médias de inverno presente e futura; (E) cepa 12, crescimento a temperaturas médias de verão presente e futura; $(\mathrm{F})$ cepa 12 -crescimento a temperaturas médias de inverno presente e futura.

Figura 36. Crescimento das cepas em temperaturas médias de inverno e verão, presentes e previstas para o final do século XXI. (A) cepa 19 - crescimento a temperaturas médias de verão presente $\left(26^{\circ} \mathrm{C}\right)$ e futura $\left(29^{\circ} \mathrm{C}\right)$; (B) cepa 19 - crescimento a temperaturas médias de inverno presente $\left(20^{\circ} \mathrm{C}\right)$ e futura $\left(24^{\circ} \mathrm{C}\right)$; (C) cepa 50 - crescimento a temperaturas médias de verão presente e futura; (D) cepa 50-crescimento a temperaturas médias de inverno presente e futura; (E) cepa 64, crescimento a temperaturas médias de verão presente e futura; (F) cepa 64 -crescimento a temperaturas médias de inverno presente e futura.

Figura 37. Crescimento das cepas em temperaturas médias de inverno e verão, presentes e previstas para o final do século XXI. (A) cepa 63 - crescimento a temperaturas médias de verão presente $\left(26^{\circ} \mathrm{C}\right)$ e futura $\left(29^{\circ} \mathrm{C}\right)$; (B) cepa 63 - crescimento a temperaturas médias de inverno presente $\left(20^{\circ} \mathrm{C}\right)$ e futura $\left(24^{\circ} \mathrm{C}\right)$; (C) cepa 62 - crescimento a temperaturas médias de verão presente e futura; (D) cepa 62-crescimento a temperaturas médias de inverno presente e futura.

Figura 38. Crescimento das cepas em temperaturas médias de inverno e verão, presentes e previstas para o final do século XXI. (A) cepa 38 - crescimento a temperaturas médias de verão presente $\left(26^{\circ} \mathrm{C}\right)$ e futura $\left(29^{\circ} \mathrm{C}\right)$; (B) cepa 38 - crescimento a temperaturas médias de inverno presente $\left(20^{\circ} \mathrm{C}\right)$ e futura $\left(24^{\circ} \mathrm{C}\right)$; (C) cepa 41 - crescimento a temperaturas médias de verão presente e futura; (D) cepa 41-crescimento a temperaturas médias de inverno presente e futura.

Figura 39. Crescimento do valor médio dos diâmetros das 10 cepas.

Figura 401. Taxa média de crescimento dos fungos $(\mathrm{cm} / \mathrm{dia})$ 


\section{LISTA DE TABELAS}

Tabela 1. Grupo climático A e suas classes climáticas de maior ocorrência. Fonte: Álvares et al. (2013).

Tabela 2. Diferenças entre o clima futuro e o clima presente para os modelos ECHAM5 e HADCM3. Fonte: Ynoue et al. (2014).

Tabela 3. Diferenças sazonais entre o clima futuro e o presente. Fonte: Ynoue et al. (2014).

Tabela 4. Sequências dos primers usados no trabalho

Tabela 5. Lista das cepas isoladas a partir de amostras de madeiras coletadas em diversos substratos de edificações históricas nos municípios de Areias, Bananal e São José do Barreiro (SJB) no Vale Histórico Paulista. Para cada cepa, estão indicados os resultados dos ensaios bioquímicos de atividade celulolítica (AC), o índice de $\mathrm{AC}$ e as respostas aos testes de atividade ligninolítica, nos casos em que foram realizados.

Tabela 6. Síntese das informações de identificação dos fungos por biologia molecular $(64,51$, $37,19$ e 47$)$ e por $(12,50,62$ e 63$)$

Tabela 7. Quadro das condições médias de umidade relativa nos locais interiores da Fazenda São Francisco

Tabela 8. Razão de mistura do vapor de água $\left(\mathrm{g} \mathrm{kg}^{-1}\right)$ nos locais indoor da São Francisco. Valor da razão de mistura média anual no ambiente exterior: $13,6 \mathrm{~g} \mathrm{~kg}^{-1}$.

Tabela 9. Quadro das condições médias de temperatura nos locais interiores da Fazenda São Francisco

Tabela 10. Quadro das condições médias de umidade relativa nos locais interiores da Fazenda São Miguel.

Tabela 11. Razão de mistura do vapor de água $\left(\mathrm{g} \mathrm{kg}^{-1}\right)$ nos locais indoor da São Miguel Grande. Valor da razão de mistura média anual no ambiente exterior: $13,6 \mathrm{~g} \mathrm{~kg}^{-1}$.

Tabela 12. Quadro das condições médias de temperatura nos locais interiores da Fazenda São Miguel

Tabela 13. Quadro das condições médias de umidade relativa nos locais interiores da Fazenda Vargem Grande

Tabela 14. Razão de mistura do vapor de água $\left(\mathrm{g} \mathrm{kg}^{-1}\right)$ nos locais indoor da Fazenda Vargem Grande. Valor da razão de mistura média anual no ambiente exterior: $12,6 \mathrm{~g} \mathrm{~kg}^{-1}$.

Tabela 15. Quadro das condições médias de temperatura nos locais interiores da Fazenda Vargem Grande

Tabela 16. Quadro das condições médias de umidade relativa nos locais interiores da Fazenda Catadupa. 
Tabela 17. Razão de mistura do vapor de água $\left(\mathrm{g} \mathrm{kg}^{-1}\right)$ nos locais indoor da Fazenda Catadupa. Valor da razão de mistura média anual no ambiente exterior: $12,6 \mathrm{~g} \mathrm{~kg}^{-1}$.

Tabela 18. Quadro das condições médias de temperatura nos locais interiores da Fazenda Catadupa.

Tabela 19. Crescimento médio do diâmetro das cepas ( $\mathrm{cm} /$ dia) em diferentes temperaturas. A última linha traz o crescimento médio de todas as cepas. 


\section{AGRADECIMENTOS}

À FAPESP pela bolsa de estudo (processo No 2013/12740-9) e pelo apoio financeiro na pesquisa (processo No 2011/51016-9).

À Profa. Dra. Dalva Lúcia Araújo de Faria e o Laboratório de Espectroscopia Molecular (LEM) do IQ-USP pelo apoio e disponibilidade do laboratório.

À Profa. Dra. Viviane Abreu Nunes Cerqueira Dantas da EACH-USP pela ajuda, ensinamentos e paciência.

À Profa. Dra. Rita Yuri Ynoue do IAG-USP por disponibilizar o relatório FAPESP com os dados sobre mudanças climáticas futuras no Vale Histórico Paulista.

Ao Prof. Dr. Felipe Santiago Chambergo Alcalde da EACH-USP pelo apoio e disponibilidade do laboratório.

Aos Srs. Lauro Maia Cavalcanti e Joseane Fontaine do Instituto Socio-Ambiental RPPN Fazenda Catadupa pela amizade, disponibilidade e parceria.

Aos Srs. Eliana Torres Ferreira Leite, Walton Ferreira Leite Júnior (Fazenda São Francisco) João Paulo Altenfelder (Fazenda São Miguel) e Maria Lúcia Gomes (Fazenda Vargem Grande) pela disponibilidade, simpatia e apoio.

Ao Prof. Dr. Andrea Cavicchioli, pela orientação, paciência, confiança e pela completa ausência de arrogância no trato com seus orientandos.

À Dra. Alejandra Teresa Fazio pela orientação e o aprendizado na área de micologia. 


\section{SUMÁRIO}

1. INTRODUÇÃ

1.1. Patrimônio Cultural edificado do Vale Histórico Paulista...............................20

1.1.1. Características climáticas do Vale do Paraíba.........................................24

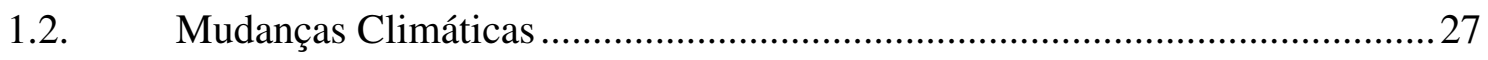

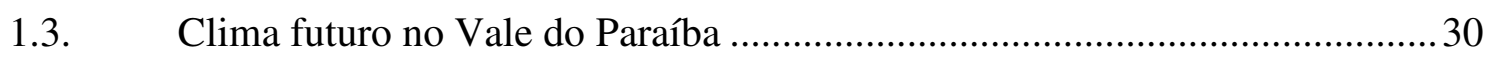

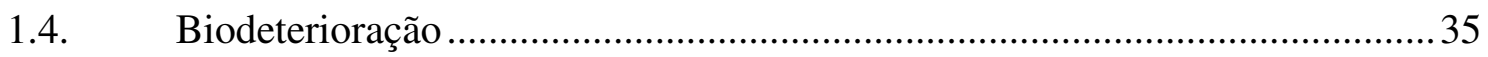

1.4.1. Mecanismos de biodeterioração ………...................................................... 36

1.4.2. Biodeterioração de materiais inorgânicos ................................................ 39

1.4.3. Biodeterioração de Materiais Orgânicos .................................................. 40

1.4.4. Biodeterioração de Materiais Compostos................................................ 48

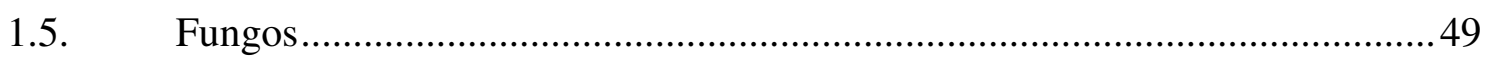

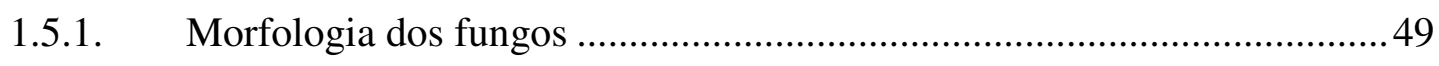

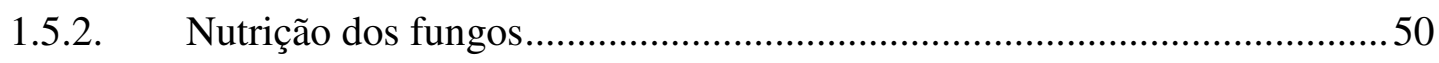

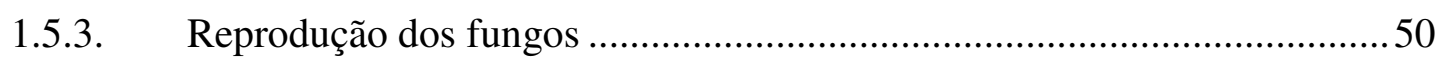

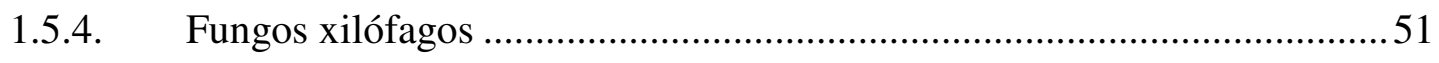

1.5.5. A biologia molecular na identificação de fungos .....................................52

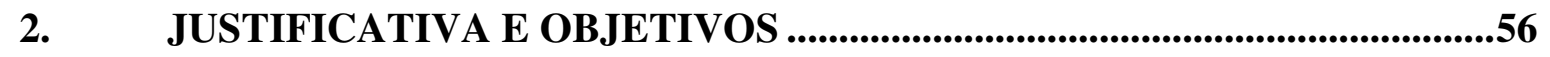

3. MATERAIS E MÉTODOS .......................................................................58

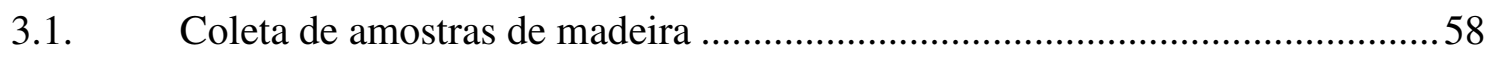

3.2. Isolamento, cultivo e conservação dos fungos das amostras de madeira .......58

3.3. Avaliação da atividade enzimática dos fungos isolados ..............................60

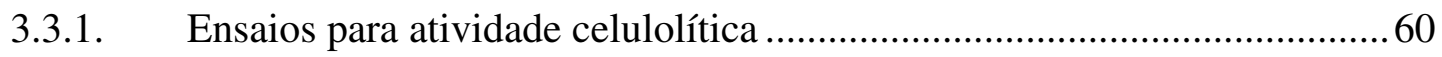

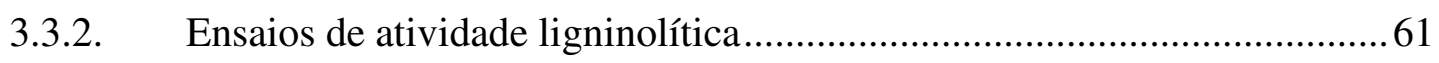

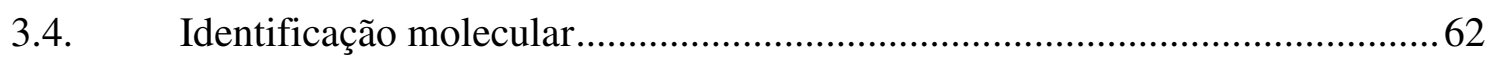

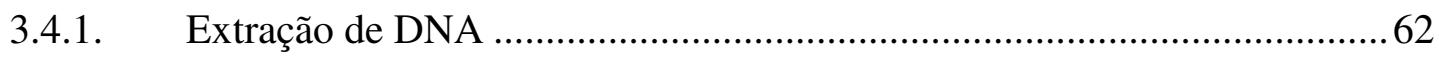

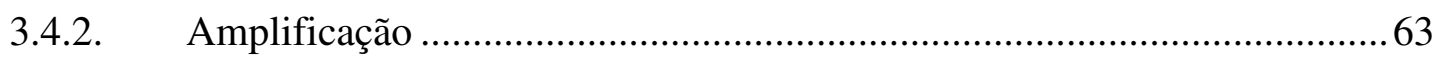


3.4.3. Purificação do DNA para sequenciamento ................................................ 64

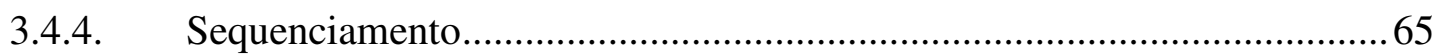

3.5. Coleta de dados para simulação de microclima...............................................66

3.6. Análise da resposta microbiológica a diferentes temperaturas ....................... 73

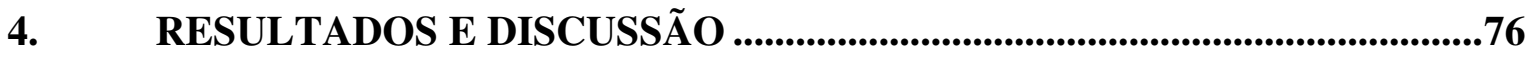

4.1. Amostras coletadas e fungos isolados .........................................................76

4.2. Avaliação da atividade enzimática dos fungos isolados .................................78

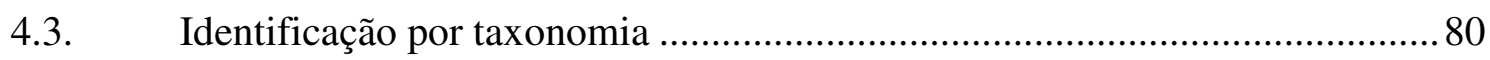

4.4. Identificação das cepas por genotipagem ............................................... 83

4.5. Avaliação das condições microclimáticas nos ambientes interiores de

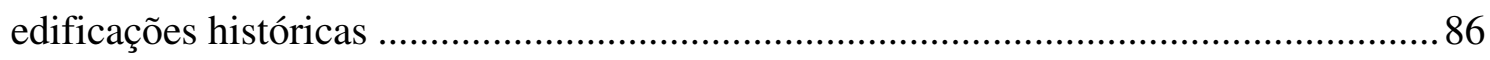

4.6. Análise da resposta microbiológica a diferentes temperaturas ..................... 103

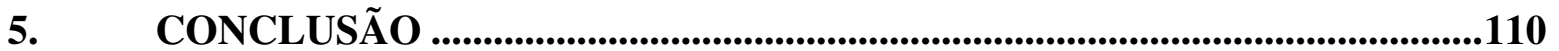

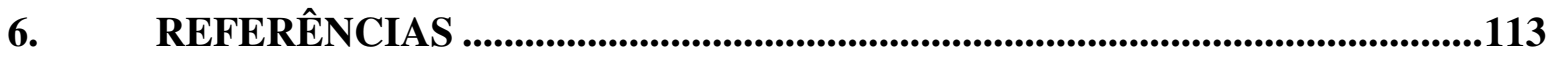




\section{INTRODUÇÃO}

O patrimônio cultural tangível, elemento fundamental de definição, manifestação e transmissão da identidade em todas as sociedades humanas, está permanentemente sujeito ao risco de desaparecer em função de fatores humanos como guerras, vandalismo, imperícia no uso (ZANIRATO, 2010). Mas os materiais que compõem esse conjunto de artefatos também "envelhecem" e degradam naturalmente, de forma mais ou menos acentuada, sendo que esse processo é fortemente influenciado direta ou indiretamente por fatores ambientais tais como luz, temperatura, umidade e poluentes atmosféricos (CAVICCHIOLI, 2008). Nesse contexto, existe hoje uma preocupação expressiva, particularmente forte em países da Europa, em investigar a exacerbação de tais impactos nos bens culturais provocada pelas mudanças climáticas. (ZANIRATO, 2010). Importante exemplo de estudo de iniciativa europeia é o Noah's Ark Project, que investiga as perspectivas de impactos das mudanças climáticas no patrimônio histórico em solo europeu (SABBIONI et al. 2007).

A UNESCO também alerta para o risco de degradação do patrimônio cultural mundial gerado pelas das mudanças de climáticas e suas prováveis consequências, como aumento do nível do mar, aumento da temperatura do ar e do solo, proliferação de pestes etc.; que podem causar danos a patrimônio construído e ao patrimônio arqueológico. Além disso, os impactos das mudanças climáticas nas sociedades podem causar mudanças no modo de vida das populações e seus modos de trabalho, socialização, culto etc., podendo ocorrer abandono de heranças culturais (UNESCO, 2006).

No Brasil, grande parte dos bens culturais está ameaçada de desaparecer a médio ou curto prazo, e até mesmo de forma brusca, como demonstram os desastres amplamente divulgados pela imprensa de Goiás Velho em 2001 e São Luiz do Paraitinga em 2010. Muitos bens estão em estado precário e, dentro desse contexto, torna-se evidente a importância de identificar fatores de deterioração, de avaliar os riscos futuros e de pensar ações de conservação preventiva. Dentre as ameaças, existem aquelas associadas a fatores ambientais, como temperatura, umidade, intemperismo, agressão por organismos biológicos, todas mais ou menos relacionadas a alterações nos padrões climáticos, genericamente indicadas como mudanças climáticas que vêm sendo projetadas pelos pesquisadores da área. 
Próximo à fronteira entre os estados de São Paulo e Rio de Janeiro, na região do Rio Paraíba do Sul, localiza-se o Vale Histórico Paulista (Figuras 1-3), região composta por seis municípios (Areias, Arapeí, Bananal, Queluz, São José do Barreiro e Silveiras) e cercada pela Serra da Mantiqueira e pela Serra da Bocaina. O Vale Histórico abriga um amplo patrimônio cultural e histórico, que pode estar ameaçado pelas mudanças climáticas globais. 


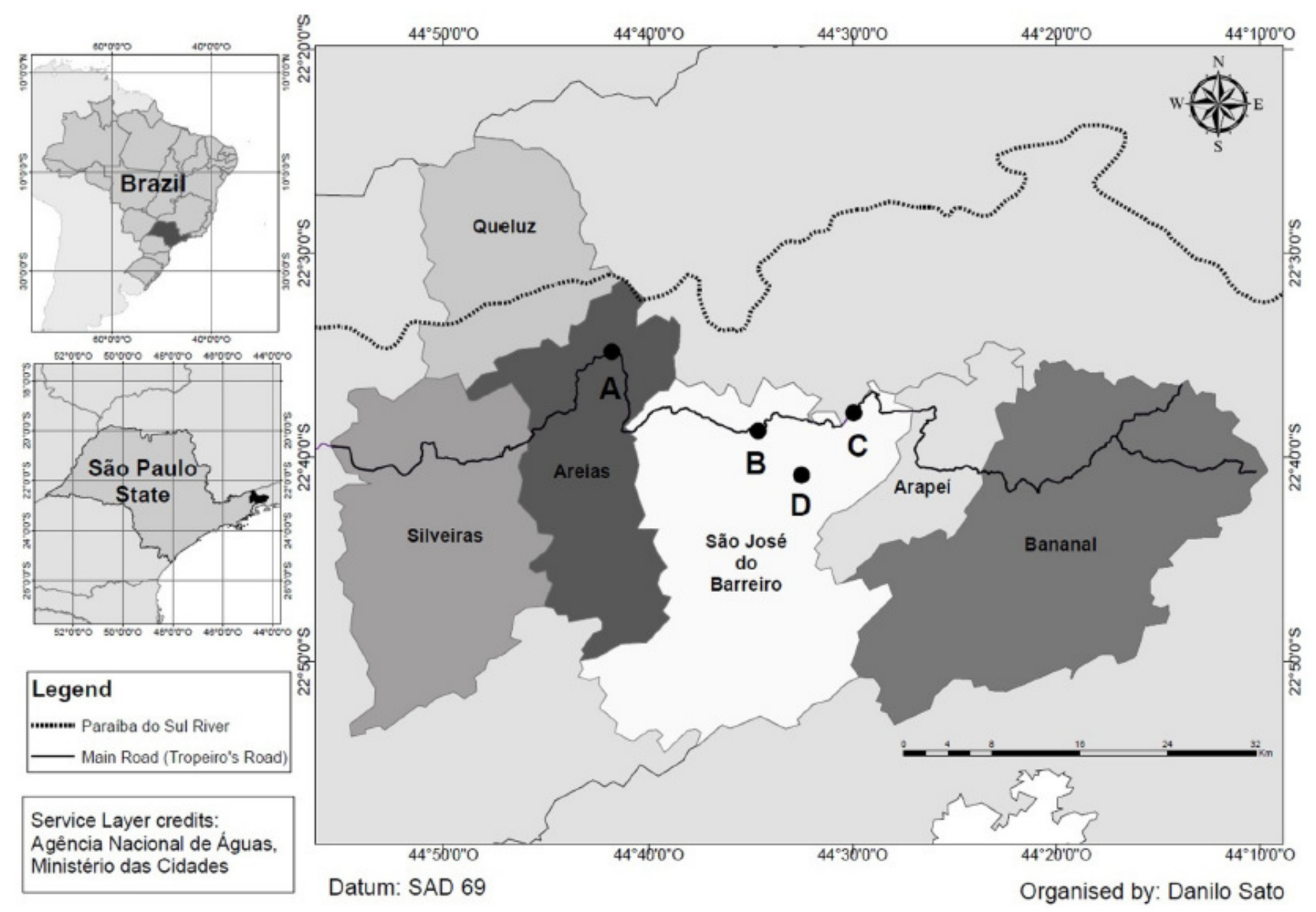

Figura 1. Mapa da localização do Vale Histórico. Fonte: Adaptado de Fazio et al. (2015) 

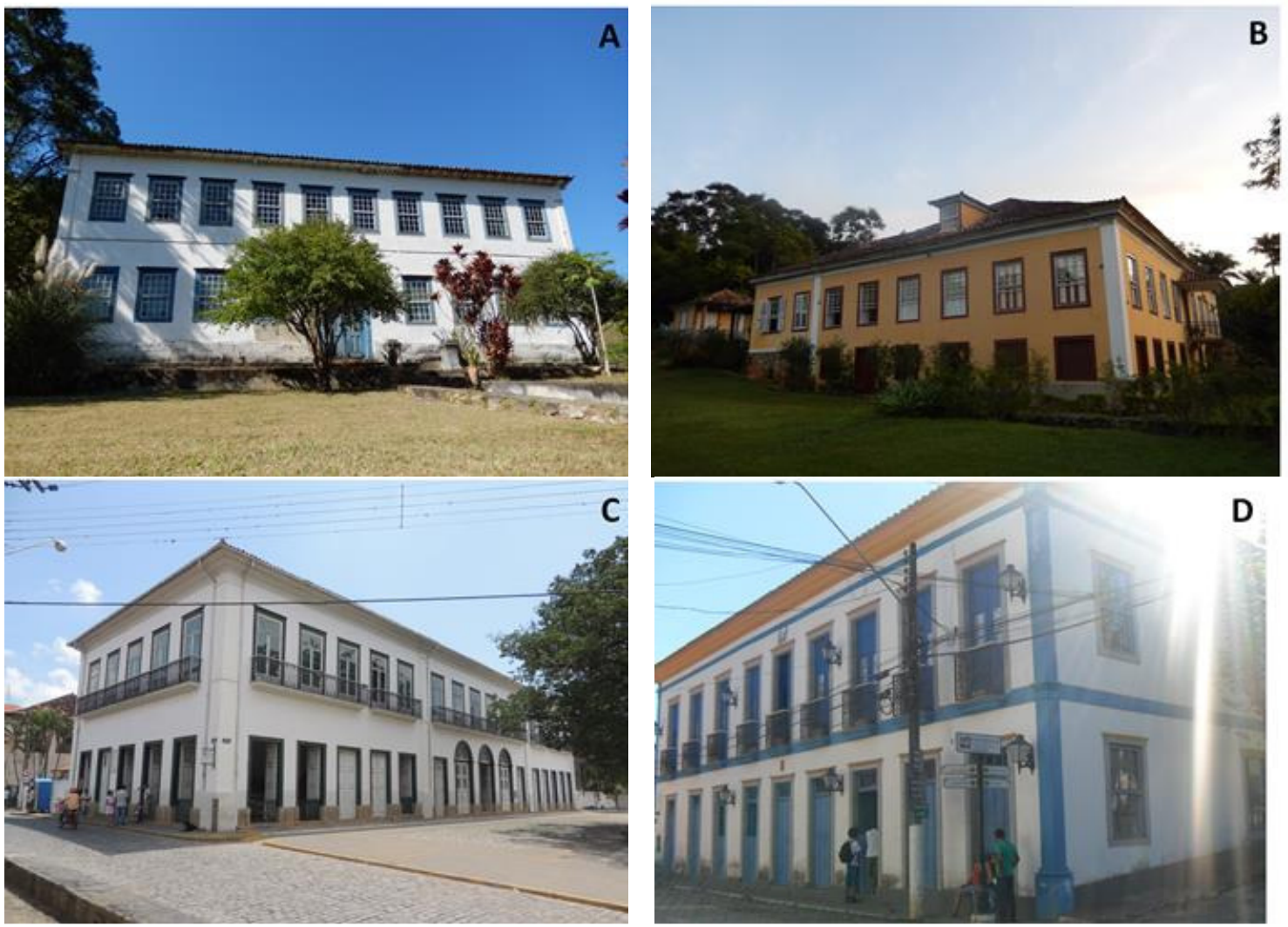

Figura 2. Paisagens urbanas e rurais no Vale Histórico Paulista. Fazenda Catadupa, São José do Barreiro (A); Fazenda Resgate, Bananal (B); Solar Aguiar Valim, Bananal (C); Solar, São José do Barreiro (D). Fonte: acervo pessoal do orientador. 

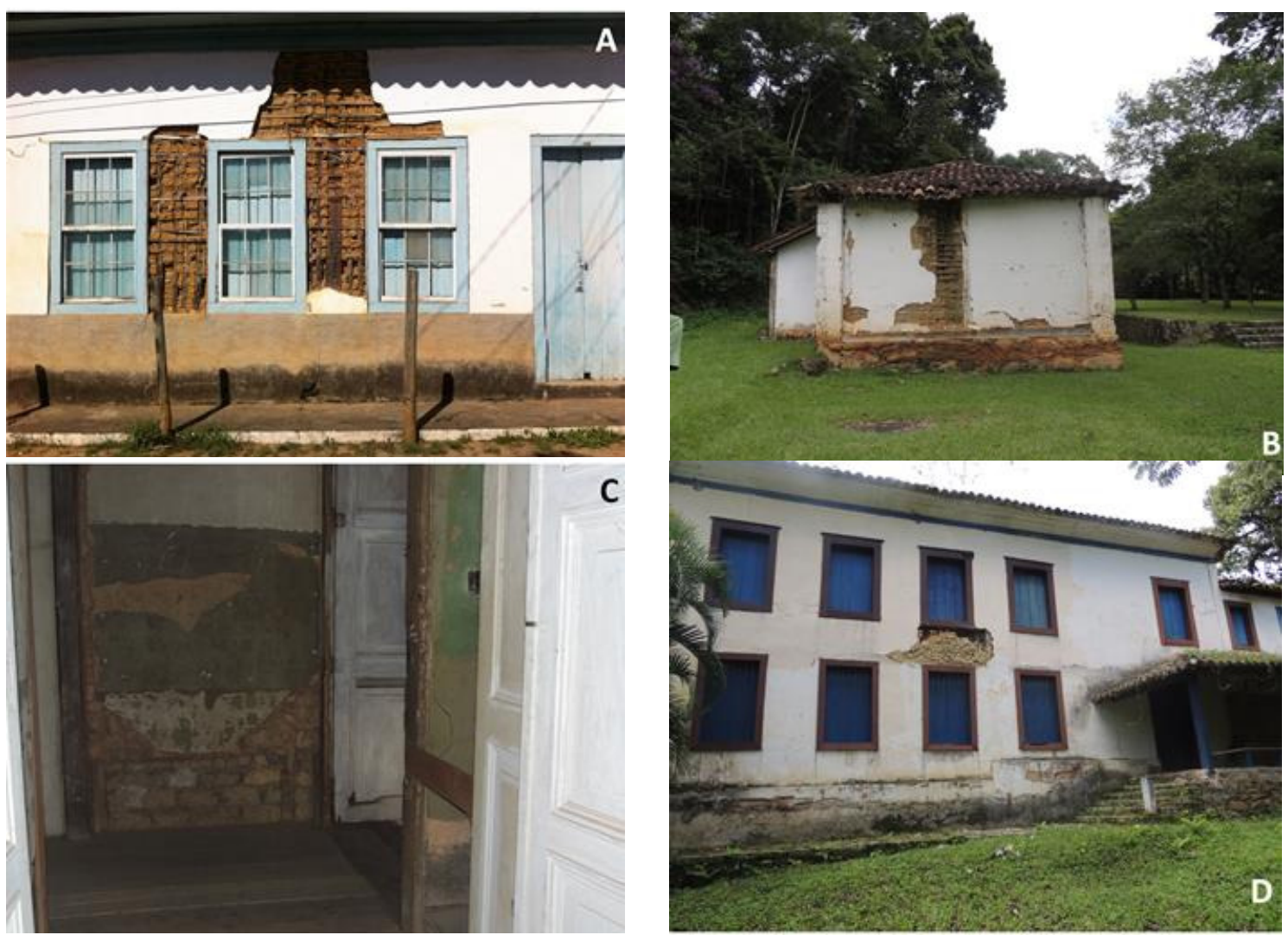

Figura 3. Exemplos de casos de deterioração estrutural nas edificações históricas do Vale Histórico Paulista. Casarão, São José do Barreiro (A); Tulha na Fazenda da Barra, São José do Barreiro (B); Interior do Solar Aguiar Valim, Bananal (C); Fazenda Casa Grande, Bananal (D). Fonte: acervo pessoal do orientador. 


\subsection{Patrimônio Cultural edificado do Vale Histórico Paulista}

A necessidade de transportar com segurança o ouro extraído na região central do Brasil colônia até o Rio de Janeiro motivou a criação de um acesso, exclusivamente terrestre, de São Paulo à capital da colônia. Até o século XVIII o caminho entre as duas localidades era feito por terra até Parati e de Parati ao Rio a via era marítima (CARRILHO, 1994).

O Caminho Novo da Piedade, que é idealizado no início do século XVIII para suprir essa necessidade, só começaria realmente a ser construído depois da restauração da Capitania de São Paulo (que havia sido extinta em 1748), com o governo de Morgado de Mateus, em um contexto de conflitos contra os espanhóis no sul do país. Apenas em 1778 a construção da estrada, que passava pela região hoje conhecida como Vale Histórico de São Paulo, é dada por concluída por Martim Lopes Saldanha, que governava a capitania na época (CARRILHO, 1994).

A partir de então, evidenciou-se a preocupação em assegurar a conservação da estrada e das condições de tráfego. Nessa conjuntura, uma interessante estratégia seria o povoamento dos arredores da estrada. Os difíceis e longos trajetos da estrada eram vencidos apenas mediante utilização de mulas e eram necessárias diversas paradas para descanso e alimentação dos tropeiros e dos animais. Dessa forma, as proximidades do Caminho da Piedade, vão sendo, pouco a pouco, ocupadas por ranchos, vendas e pequenas propriedades voltadas para a criação (principalmente de porcos) e lavoura de policultura (milho, mandioca, arroz, feijão) (CARRILHO, 1994; MAIA; HOLANDA,1975).

Assim, estabelece-se na região uma economia da subsistência que vai continuar importante, mesmo com a decadência do ciclo da mineração e, inclusive, durante o "ciclo do dos engenhos". (MAIA; HOLANDA,1975).

No final do século XVIII, o ciclo econômico da mineração entrava em decadência. Essa decadência é, segundo Holanda e Maia (1975), provavelmente, um dos fatores que desencadeou o aumento da entrada de migrantes no Vale do Paraíba paulista, vindos de Minas Gerais, e o surgimento de das vilas que dariam origem aos municípios do Vale Histórico. Em 1781, surgiam os núcleos que culminariam nas vilas 
de Bananal, Areias e Silveiras. Em 1800 é criado um aldeamento indígena do qual, futuramente, surgiria o município de Queluz.

Nesse período, estabelecia-se no Vale do Paraíba o ciclo dos engenhos (o ciclo da cana de açúcar), que produziu riqueza principalmente em Guaratinguetá, não sendo tão importante no Vale como um todo. Na mesma época, vale ressaltar, ainda podia ser observada a importância da "economia de subsistência". Nota-se, por exemplo, além dos canaviais, fazendas de criação por todo Vale do Paraíba, milharais em Bananal e plantações de mandioca em Silveiras. Não houve, durante o ciclo açucareiro, grandes transformações sociais e estruturais no Vale. (MAIA; HOLANDA, 1975). O seguinte trecho de Holanda e Maia (1975, p. 28) é ilustrador dessas ideias:

\begin{abstract}
A verdade é que na província de São Paulo e, mais ainda, no Vale do Paraíba da época, não sobrou tempo para desenvolver-se um complexo independente da cana de açúcar. A passagem da fase da lavoura de subsistência fez-se aqui sem sobressaltos e descontinuidades, e, em realidade, a riqueza nova não é tamanha que chega a apagar as antigas usanças.
\end{abstract}

O que realmente viria a transformar a economia da região seria o café. Já havia no século XXVIII modestas plantações de café em alguns locais da capitania de São Paulo, inclusive na capital, porém sem grande importância comercial (TAUNAY,1935 apud BENINCASA, 2007; OLIVEIRA,1993 apud BENINCASA, 2007). Os primeiros cafezais economicamente relevantes em solo paulista serão os que se desenvolvem proximamente a fronteira fluminense, na zona costeira: Ubatuba, Caraguatatuba e São Sebastião. Entretanto é no Vale do Paraíba, que a economia cafeeira tem o seu primeiro grande impulso em território nacional (PRADO Jr, 1983). Os cafezais vão primeiramente se estabelecer na parte fluminense do Vale e depois se difundir em território paulista (BENINCASA, 2007).

A produção do café começa a ser implantada na região do Vale histórico entre o final século XVIII e o início do século XIX, depois que os primeiros cafezais economicamente relevantes em solo paulista tinham sido desenvolvidos na zona costeira proximamente a fronteira fluminense: Ubatuba, Caraguatatuba, São Sebastião. Será justamente no Vale do Paraíba que o café terá o seu primeiro momentum em território nacional (PRADO JÚNIOR, 1983), se estabelecendo antes na parte 
fluminense do Vale e depois no lado paulista (BENINCASA, 2007). Com a sua entrada na região, essa lavoura praticamente toma o lugar de uma modesta economia preexistente baseada no tropeirismo e na cultura da cana de açúcar.

A partir de então, a produção cafeeira no Vale do Paraíba cresceria intensamente e o Vale Histórico, em meados do século XIX, concentraria grande parte da riqueza gerada na província de São Paulo e no Brasil. Assim sendo, o espaço sofreu grandes transformações, as vilas cresceram e tornaram-se cidades e, no campo, a lavoura do café provocaria a supressão de imensas áreas de mata atlântica (CARRILHO, 2006; MILLIET, 1982).

Os cafeicultores enriquecidos ganharam importância política e muitos se tornaram barões do império. Assim surgia uma elite cafeeira que, a fim de ostentar sua riqueza e prestígio, construiu suntuosas edificações, de estilo colonial ou neoclássico, tanto no meio rural quanto no urbano (D'ELBOUX, 2006)

Entretanto, a rápida ascensão da economia cafeeira no Vale do Paraíba não tardou a dar lugar a um declínio igualmente vertiginoso. Desde 1886, a atividade cafeeira já começava a decrescer e a perder espaço para outras regiões do oeste da província de São Paulo, muito embora continuasse sendo a principal atividade do vale até meados do século seguinte.

Alguns fatores são importantes para explicar a decadência da produção cafeeira no vale. Um desses fatores foi a degradação do solo, acelerada por formas de plantio sabidamente inadequadas. (BENINCASA, 2007). Outro fenômeno relevante, que impulsionou a migração do café para o oeste do estado, foi a construção de estradas de ferro como as que ligavam Santos a Jundiaí, concluída em 1867 e Jundiaí a Campinas, que, em 1888, chegaria até Franca (HOLANDA; MAIA, 1975; MILLIET, 1982; PUPIM, 2008). Finalmente, deve-se destacar o processo de abolição da escravatura. Segundo Benincasa (2007), não houve preocupação em se adequar ao novo modelo de produção que surgia com a transição do trabalho servil para a mão-de-obra imigrante.

Após a decadência da economia cafeeira na local, não houve grandes transformações econômico-sociais no Vale Histórico. A economia local é, atualmente, fortemente dependente da pecuária cuja alternativa única parece ser o turismo. Por diversos motivos, as cidades da região parecem ter "parado no tempo". Essa estagnação, que foi descrita por Monteiro Lobato em 1919, originou a expressão de "cidades mortas" com a qual o autor alcunhou essa região (LOBATO, 2007). 
De qualquer forma, as fazendas e as edificações urbanas construídas durante o ciclo do "ouro verde", tanto as mais monumentais, quanto as mais simples, são documentos que contribuem com a composição da memória e da identidade coletiva, em nível local e nacional. As fazendas antigas, com suas casas grandes e seus renques de palmeiras imperiais, as pinturas murais e o mobiliário revelam a riqueza dos barões da época, enquanto as escuras e úmidas senzalas remetem à exploração de seres humanos escravizados trazidos do continente africano, base da economia do café do século XIX e triste capítulo da história do Brasil (CARRILHO, 2006; PRADO JÚNIOR, 1983). Ademais, a arquitetura em terra, isto é, terra não cozida (taipa, adobe, pau-a-pique), é base da construção do patrimônio edificado da região e um registro tangível de saberes populares sobre formas tradicionais e em boa parte esquecidas de se construir (BENINCASA, 2007; RIBEIRO, 2003).

Diante disso, faz-se necessário destacar que, apesar da importância dos bens da região, o patrimônio do Vale foi pouco lembrado pelas políticas federais de preservação, o que foi, até certo ponto, seguido pelas políticas estaduais, fato que pode ter contribuído com paulatino desaparecimento das edificações históricas que tem sido verificado no Vale (CARRILHO, 2006). Contrapõem-se a esse desinteresse por parte das políticas oficias de preservação algumas esparsas iniciativas da sociedade civil como a ação do Instituto PRESERVALE (Instituto de Preservação e Desenvolvimento do Vale do Paraíba) que, ao promoverem a valorização do patrimônio histórico-cultural e ambiental e apoiarem o turismo ecológico e cultural no Vale do Paraíba, indicam a possibilidade - e talvez a inevitabilidade - de formas de desenvolvimento local vinculadas a processos de conservação do patrimônio (MANBERTI, 2006; MARINS, 2008).

Não há dúvidas, de qualquer maneira, de que o patrimônio cultural ainda preservado no Vale está ameaçado de desaparecer em curto prazo . Muitos bens estão em estado precário e, dentro desse contexto, torna-se evidente a importância de identificar fatores de deterioração, de avaliar os riscos futuros e de pensar ações de conservação preventiva. Dentre as ameaças, existem aquelas associadas a fatores ambientais, como temperatura, umidade, intemperismo, agressão por organismos biológicos, todas mais ou menos relacionadas a alterações nos padrões climáticos, genericamente indicadas como mudanças climáticas que vêm sendo projetadas pelos pesquisadores para a região sudeste do país (onde se encontra o Vale Histórico). 


\subsubsection{Características climáticas do Vale do Paraíba}

O Vale do Paraíba está inserido no grande Domínio Morfoclimático dos Mares de Morros. (AB'SABER, 2003). Os mares de morros estendem-se por toda a porção litorânea da costa leste Brasileira (englobando parte do litoral nordestino, o litoral sudeste e o litoral sul como pode ser observado na Figura 4). Caracteriza-se por um relevo com muitos "morros de formas residuais e curtos em sua convexidade, com muitos movimentos de massa generalizados." Os processos de intemperismo são intensos, o que explica o fato das rochas da região encontrarem-se geralmente em decomposição. Os ventos carregados de umidade vindos do oceano geram bom volume de precipitação. A vegetação natural é de mata Atlântica, com poucas áreas nativas muito importantes aos ecossistemas ali existentes. Devido a grande extensão territorial, cobrindo uma grande variação latitudinal, existe uma grande variação climática no domínio. 


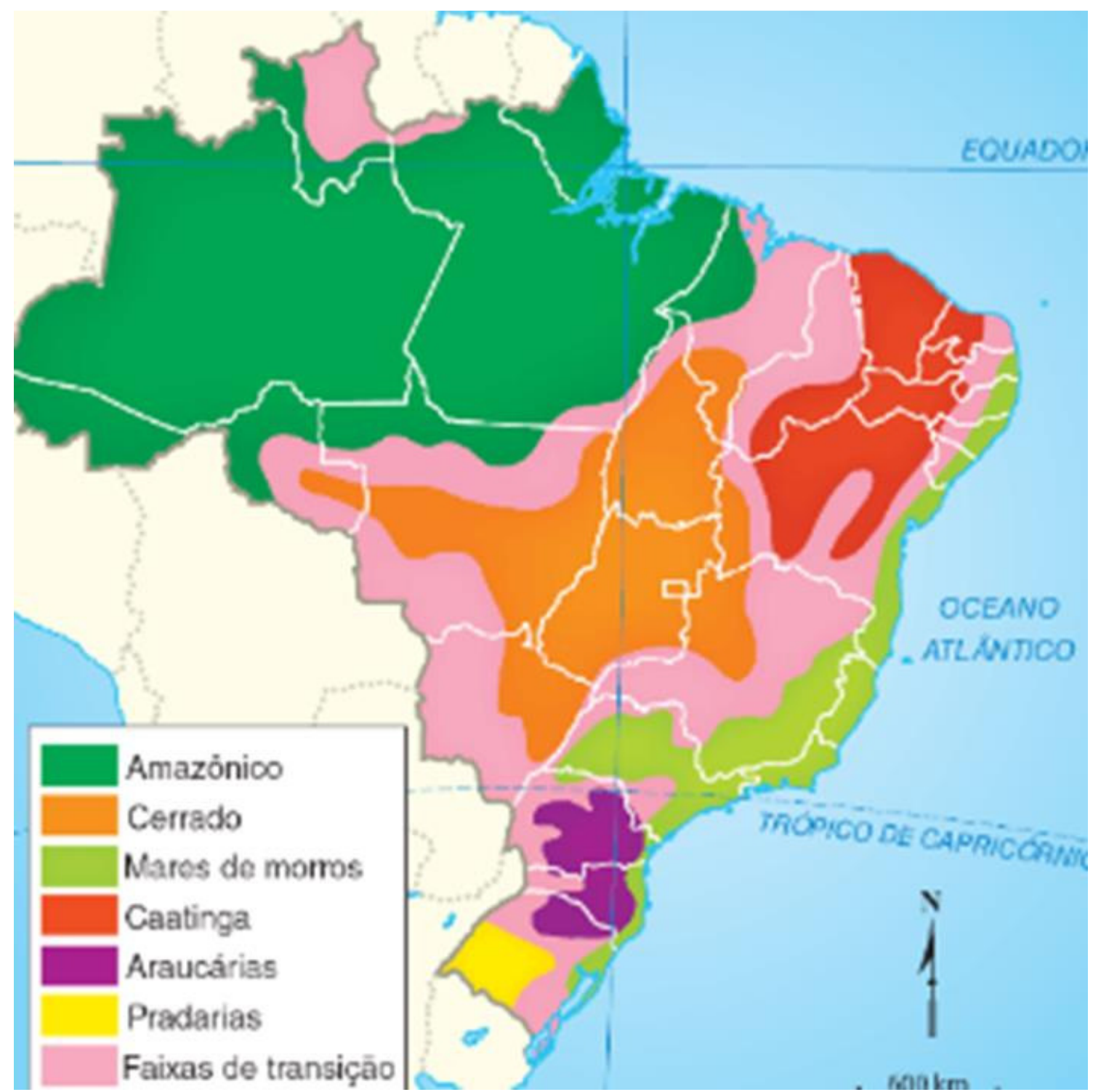

Figura 4. Mapa do Brasil com os domínios morfoclimáticos. Em verde claro, os "mares de morro", que englobam o Vale do Paraíba. Fonte: http://docplayer.com.br/2314095-Dominiosmorfoclimaticos-brasileiros.html

Uma classificação climática muito importante mundialmente é a de Köppen (KÖPPEN , 1936 apud ÁLVARES et al., 2013) que consiste na divisão clima do clima em cinco grandes grupos climáticos designados pelas letras A, B, C, D, E, sendo A) clima tropical; B) clima seco; C) clima subtropical úmido; D) temperado continental; E) clima polar.

Além desses cinco grupos climáticos, existem diversas classes climáticas. As classes do clima tropical estão listadas na Tabela 1. 
Tabela 1. Grupo climático A e suas classes climáticas de maior ocorrência. Fonte: Álvares et al. (2013).

A Clima Tropical

Af Clima Tropical sem estação seca

Am Clima Tropical de monção

Aw Clima Tropical com estação seca no verão

As Clima Tropical com estação seca no inverno

Com esta classificação, Alvares et al. (2013) identificaram 12 sub-grupos climáticos em todo o território brasileiro (Af, Am, Aw, As, BSh, Cfa, Cfb, Cwa, Cwb, Cwc, Csa e Csb) e apenas 6 no estado de São Paulo (Af, Aw, Cfa, Cfb, Cwa e Cwb), como mostra a Figura 5.

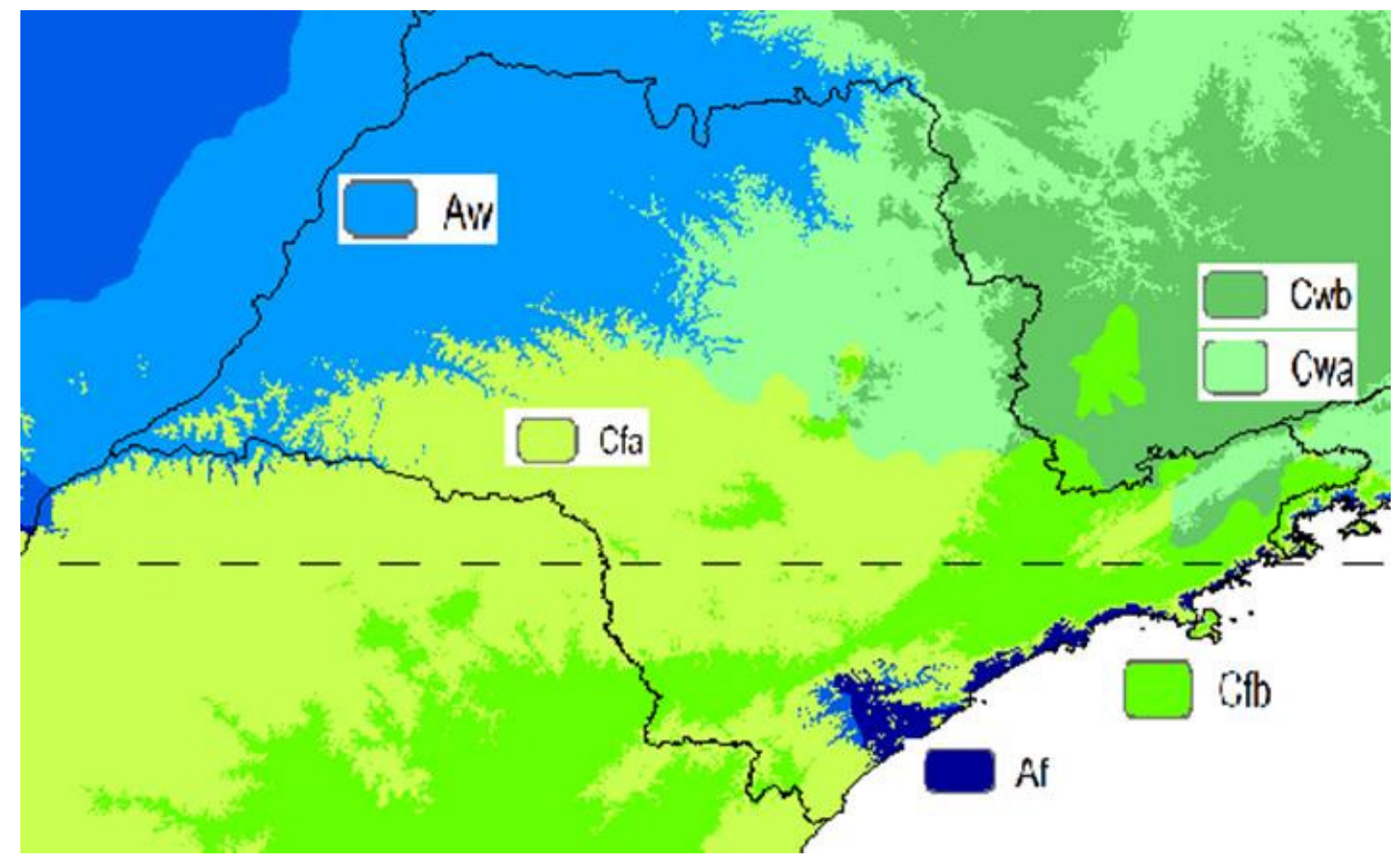

Figura 5. Classes climáticas da classificação de Köpper adaptada por Alvares et al. (2013). Af, Tropical sem estação seca; Aw, tropicalcom inverno seco; Cwa, Subtropical úmido com inverno seco e verão quente; Cwb, Subtropical úmido com inverno seco e verão temperado; Cfa, Subtropical úmido com verão quente e sem estação seca; e; $\mathbf{C f b}$, Subtropical úmido com verão temperado e sem estação seca.

O Vale do Paraíba está inserido nas regiões Cfa, Cfb, Cwa e Cwb e, portanto, tem como características verões temperados a quentes (dependendo basicamente da altitude), médias anuais de temperatura entre $17^{\circ} \mathrm{C}$ e $19^{\circ} \mathrm{C}$ e pluviosidade média de 1500 mm/ano. 
Como consequência de sua localização entre $21^{\circ}$ e $24^{\circ} \mathrm{S}$ e da presença da barreira orográfica formada pela Serra da Mantiqueira, no Vale do Paraíba há forte atuação das massas Tropical Atlântica (Ta - quente e úmida), Tropical Continental (Tc - quente e seca), Polar Atlântica (Pa - fria e úmida) e Equatorial Continental (Ec quente e seca) (MOURA, 2006). Logo, a região sofre influências de massas quentes, frias, secas e úmidas.

Por outro lado, alguns fatores favorecem altos níveis de precipitação no Vale do Paraíba como a posição latitudinal e a proximidade com o oceano, que proporcionam grande incidência de radiação solar e a alto nível de evaporação; e a topografia acidentada da região, que favorece circulações vale-montanha e brisas marítima e terrestre.

O volume das chuvas no Vale do Paraíba está concentrado no período do ano entre outubro e março, quando o acúmulo das chuvas é maior do que nos outros meses. A diferença entre a ocorrência ou não de estação seca se dá pelos índices pluviométricos serem maiores ou não que $40 \mathrm{~mm}$ no mês mais seco.

\subsection{Mudanças Climáticas}

Este trabalho tem como um dos temas centrais a problemática das mudanças climáticas, portanto, é importante que se tenha com clareza acerca do conceito de clima. Segundo o glossário do IPCC (PACHAURI; REISINGER, 2007, p. 78) o clima:

Pode ser de definido como o tempo meteorológico médio ou, mais rigorosamente, como a descrição estatística em termos de média e variabilidade das magnitudes relevantes durante um período de tempo, variando de meses a milhares de milhões de anos. O período normalmente utilizado para essa descrição estatística é de 30 anos, segundo a definição da Organização Meteorológica Mundial (OMM). As magnitudes são quase sempre variáveis de superfície (por exemplo, temperatura, precipitação e vento).

Uma definição de mudanças climáticas muito utilizada é a da United Nations Framework Convention on Climate Change (UNFCCC, 1992, p. 4), na qual, aponta-se 
que mudança climática diz respeito a um conjunto de fenômenos atmosféricos decorrentes "das atividades humanas que alteram a composição global da atmosfera, sendo mais intensa do que a variabilidade climática observada ao longo de períodos de tempo comparáveis". Outra definição importante é a dada pelo Intergovernmental Panel on Climate Change (PACHAURI; REISINGER, 2007, p. 30), segundo a qual, "mudanças climáticas referem-se às mudanças no estado clima que podem ser identificadas pelas mudanças na média e/ou variabilidade de suas propriedades, e que persistem por um extenso período", sendo essas mudanças causadas por variabilidade natural, ou atividade humana. Qualquer uma das duas definições serve para os objetivos desse trabalho.

As mudanças climáticas globais são consequência de um desequilíbrio no balanço radiativo terrestre. Considerando uma escala de tempo humana, pode-se dizer que a Terra mantém um equilíbrio entre radiação recebida pela Terra e a radiação por ela emitida. Esse equilíbrio é chamado de balanço radiativo. Observa-se que no balanço radiativo terrestre, a radiação emitida pelo sol que chega à atmosfera é de $342 \mathrm{~W} \mathrm{~m}^{-2}$. Parte dessa energia é refletida por nuvens, atmosfera e aerossóis, sendo que o equivalente a $235 \mathrm{~W} \mathrm{~m}^{-2}$ é absorvido parte pela atmosfera, parte pela superfície.

A energia radiação reemitida pela superfície terrestre é, no entanto, de $390 \mathrm{~W} \mathrm{~m}^{-}$ ${ }^{2}$. Isso ocorre porque parte da radiação infravermelha emitida pela superfície é absorvida pelos gases de efeito estufa e reemitida, em parte, em direção à superfície que irá absorver a radiação, impedindo a dispersão dessa energia. Dessa maneira, a superfície terrestre mantém-se aquecida a uma temperatura global média de $15^{\circ} \mathrm{C}$ aproximadamente.

Alterações nesse balanço radiativo podem causar mudanças na temperatura média global e diversas alterações climáticas. Nesse âmbito, é importante fazer projeções acerca das alterações das forçantes radiativas (FR) do sistema climático.

Forçante radiativa tem sido usada pelos trabalhos do IPCC para referir-se a uma perturbação sobre o balanço radiativo do sistema climático terrestre, como por exemplo, no estudo dos gases de efeito de estufa de longa vida (LLGHG) (Ramaswamy et al., 2001). A definição usada pelo IPCC para forçante radiativa do sistema climático é a seguinte: 
A forçante radiativa do sistema superfície-troposfera, devido a perturbação ou a introdução de um agente (por exemplo, mudanças na concentração de gases de efeito estufa), é a mudança líquida no fluxo radiativo na tropopausa que induz, posteriormente, a ajustes da temperatura estratosférica ao novo fluxo radiativo, sem alterações, nas temperaturas da superfície e da troposfera (Ramaswamy et al., 2001, p. 353).

A FR provoca um desequilíbrio no fluxo radioativo líquido na tropopausa. As consequências desse desequilíbrio sobre as temperaturas atmosféricas podem ser divididas em quatro etapas: (FORSTER; RAMASWAMY, 2007)

•FR instantâneo: não há alteração da temperatura na atmosfera;

-FR ajuste estratosférico: altera-se a temperatura estratosférica mantendo-se as temperaturas da superfície e da troposfera fixas;

-FR alteração temperatura da superfície zero: a temperatura da troposfera também é alterada sem perturbações à temperatura da superfície;

-Equilíbrio da resposta climática: a temperatura da superfície também sofre alteração, buscando um novo equilíbrio no fluxo radiativo.

O conceito de forçante radiativa é útil para quantificar e classificar os diferentes agentes determinantes das mudanças climáticas, possibilitando uma medição limitada das mudanças climáticas, não tentando retratar a reposta total do clima (FORSTER; RAMASWAMY, 2007).

A emissão de agentes forçantes, como os LLGHG; aerossóis; precursores de aerossóis; precursores de ozônio; e depletores de ozônio, é o mais importantes condutor de mudanças climáticas. As concentrações dos LLGHG, por exemplo, vêm sabidamente aumentando desde meados do século XVIII (período pós Revolução Industrial).

As previsões climáticas do IPCC são desenvolvidas a partir de informações sobre as futuras concentrações e emissões de gases de efeito estufa, aerossóis e outros condutores do clima. No caso do IPCC AR5, esse tipo de informação está expressa nos RCP's (Representative Concentration Pathways - Caminhos representativos de concentração), que são, por assim dizer, a terceira geração de cenários de emissão do IPCC e substituem os SRES (Special Reporton Emissions Scenarios - Relatório Especial sobre Cenários de Emissões). São quatro RCP's com diferentes valores de forçante radiativa total para ano de 2100 em relação 1750: (i) RCP 2.6, cenário de 
mitigação com forçante radiativa prevista em $2,6 \mathrm{~W} \mathrm{~m}^{-2}$; (ii) $\mathrm{RCP} 4.5$, cenário de estabilização com forçante prevista em 4,5 $\mathrm{W} \mathrm{m}^{-2}$; (iii) RCP 6.0, cenário de estabilização com previsão de $6,0 \mathrm{~W} \mathrm{~m}^{-2}$; e (iv) RCP 8.5, cenário mais "pessimista" de aumento de emissões com previsão de $8,5 \mathrm{~W} \mathrm{~m}^{-2}$. Com relação às projeções de mudanças na temperatura média da superfície global, as previsões com o RCP 2.6 indicam aumentos entre $0,3{ }^{\circ} \mathrm{C}$ e $1,7^{\circ} \mathrm{C}$; com o RCP 4.5 estimam-se aumentos entre 1,1 e 2,6 ${ }^{\circ} \mathrm{C}$; com o RCP 6.0, aumentos entre 1,4 e 3,1 ${ }^{\circ} \mathrm{C}$; com o RCP 8.5, aumentos estimados entre 2,6 e $4,8^{\circ} \mathrm{C}$. (IPCC, 2013)

Apesar de já terem sido substituídos, os SRES foram utilizados nas simulações climáticas discutidas nesse trabalho, portanto, é importante discuti-los brevemente. Os SRES são divididos em quatro grupos, A1, A2, B1 e B2. O grupo A1, considera um mundo com um rápido crescimento econômico, com um auge de números de habitantes atingido no meio do século XXI e uma rápida inserção de novas e mais eficientes tecnologias. O A1 é dividido em três cenários, com diferentes direções no que diz respeito a fontes de energia. O cenário A1FI baseia-se na utilização intensiva de energia fóssil, o cenário AIT considera o uso de fontes de energia não fosseis, e o A1B considera o uso balanceado de todos os tipos de energia. (NAKICENOVIC \& SWART, 2000).

O cenário B1 descreve um mundo convergente com o mesmo contingente populacional do cenário $\mathrm{A} 1$, mas com mudanças mais rápidas nas estruturas econômicas em direção uma economia de serviços e informação. B2 descreve um mundo com crescimento econômico e populacional intermediários, e com ênfase em soluções locais para a economia, questões sociais e sustentabilidade ambiental. O A2 considera um mundo muito heterogêneo, com alto crescimento populacional, alto desenvolvimento econômico e baixo desenvolvimento tecnológico. (NAKICENOVIC \& SWART, 2000)

\subsection{Clima futuro no Vale do Paraíba}

Simulações climáticas para a região do Vale do Paraíba Paulista foram disponibilizadas pela Profa. Rosmeri Porfírio da Rocha e analisados pela Profa. Rita Y. Ynoue (ambas do IAG-USP) como resultado de projeto FAPESP (N. 2011/51016-9) ao qual esse projeto de mestrado esteve vinculado durante o início da vigência. Os dados 
estão disponíveis nos relatórios "Clima presente e futuro do Vale Histórico Paulista" (YNOUE et al. 2013; 2014). Os relatórios se baseiam nos resultados das simulações numéricas do modelo regional RegCM3. Foram feitas três simulações para o cenário A1B, utilizando como condições iniciais e de fronteira a seguinte base de dados: (i) ERA-INTERIM, análise de campos meteorológicos com resolução de aproximadamente $80 \mathrm{~km}$ x $80 \mathrm{~km}$, para o período de 1989 a 2008. (simulação do clima atual/controle); (ii) HadCM3, para os períodos de 1960 a 1990 (clima atual) e para o período de 2070 a 2100 (clima futuro); (iii) ECHAM5: para os mesmos períodos do HadCM3.

O relatório traz comparativos entre dados de monitoramento das estações meteorológicas do Instituto Nacional de Meteorologia (INMET) dos municípios de Taubaté e São Luís do Paraitinga e os dados das simulações com o RegCM3.

Verifica-se nas 6 e 7que as simulações do ECHAM5 e do ERA-INTERIM são mais próximas das observações das estações meteorológicas, no que se diz respeito ao clima atual. Não obstante tanto o ECHAM5 quanto o HadCM3 projetam um aumento de $3^{\circ} \mathrm{C}$ para o clima futuro, tanto para temperaturas máximas quanto para temperaturas mínimas. 


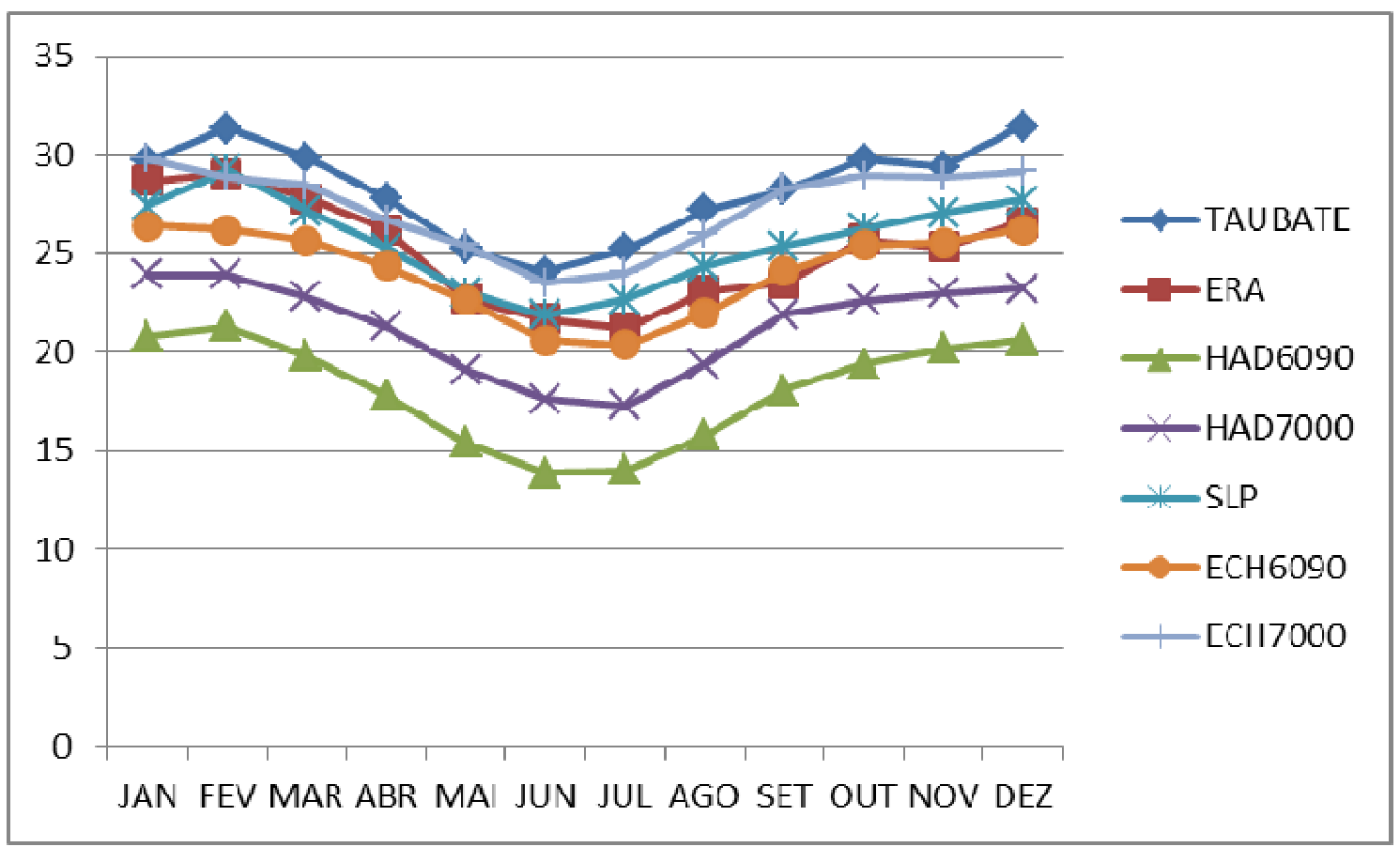

Figura 6. Comparação entre temperaturas máximas mensais $\left({ }^{\circ} \mathrm{C}\right.$ ) observadas (estações de Taubaté e São Luís do Paraitinga - SLP) e simuladas para clima atual (ERA, HAD6090 e ECH6090) e futuro (HAD7000 e ECH7000). Fonte: Ynoue, et al. (2014).

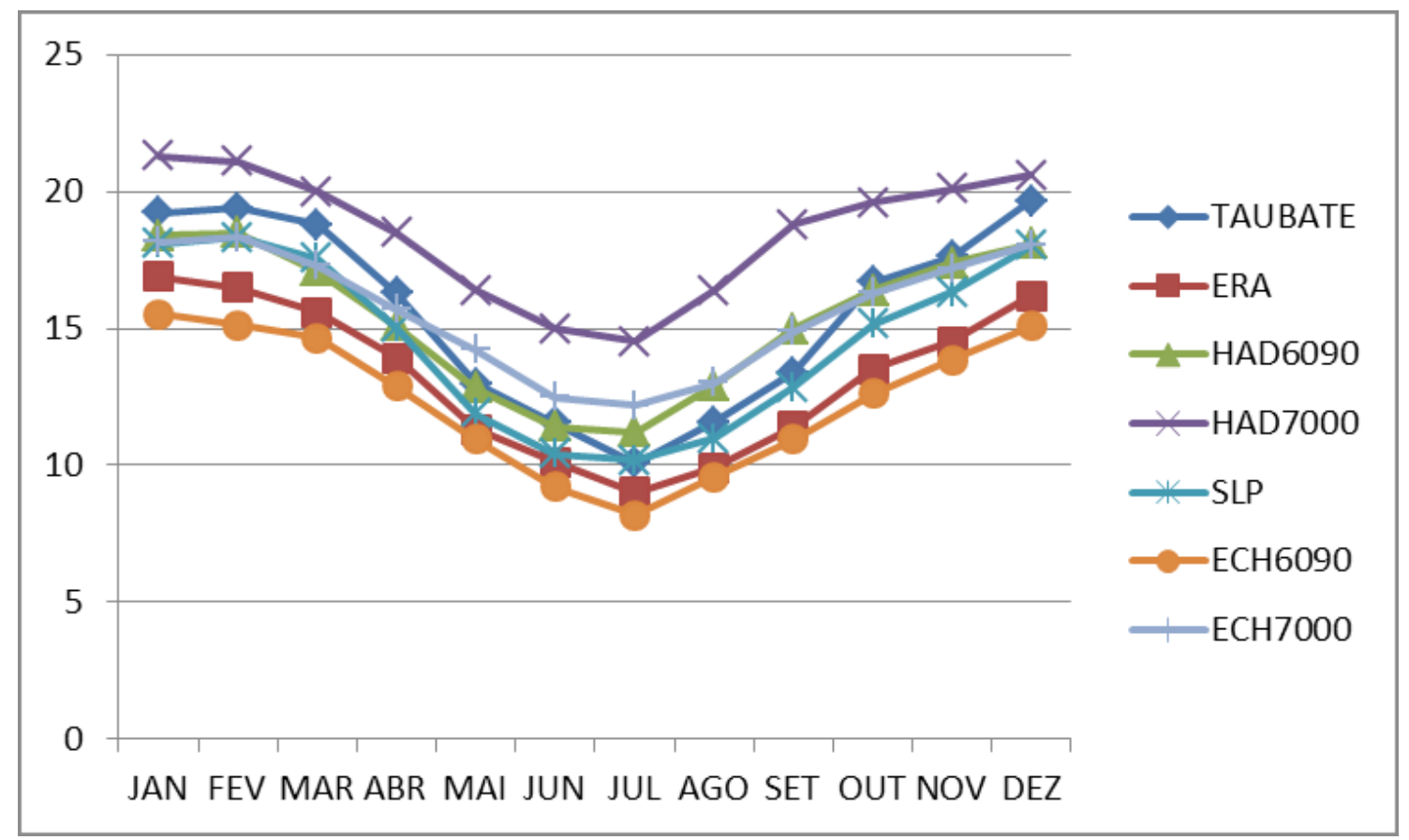

Figura 7. Comparação entre temperaturas mínimas mensais $\left({ }^{\circ} \mathrm{C}\right.$ ) observadas (estações de Taubaté e São Luís do Paraitinga) e simuladas para clima atual (ERA, HAD6090 e ECH6090) e futuro (HAD7000 e ECH7000). Fonte: Ynoue et al. (2014). 
$\mathrm{Na}$ Figura 8 observa-se que as simulações do HadCM indicam ligeira diminuição da UR relativa média mensal no clima futuro, porém a diminuição não ultrapassa os $3 \%$ em nenhum mês.

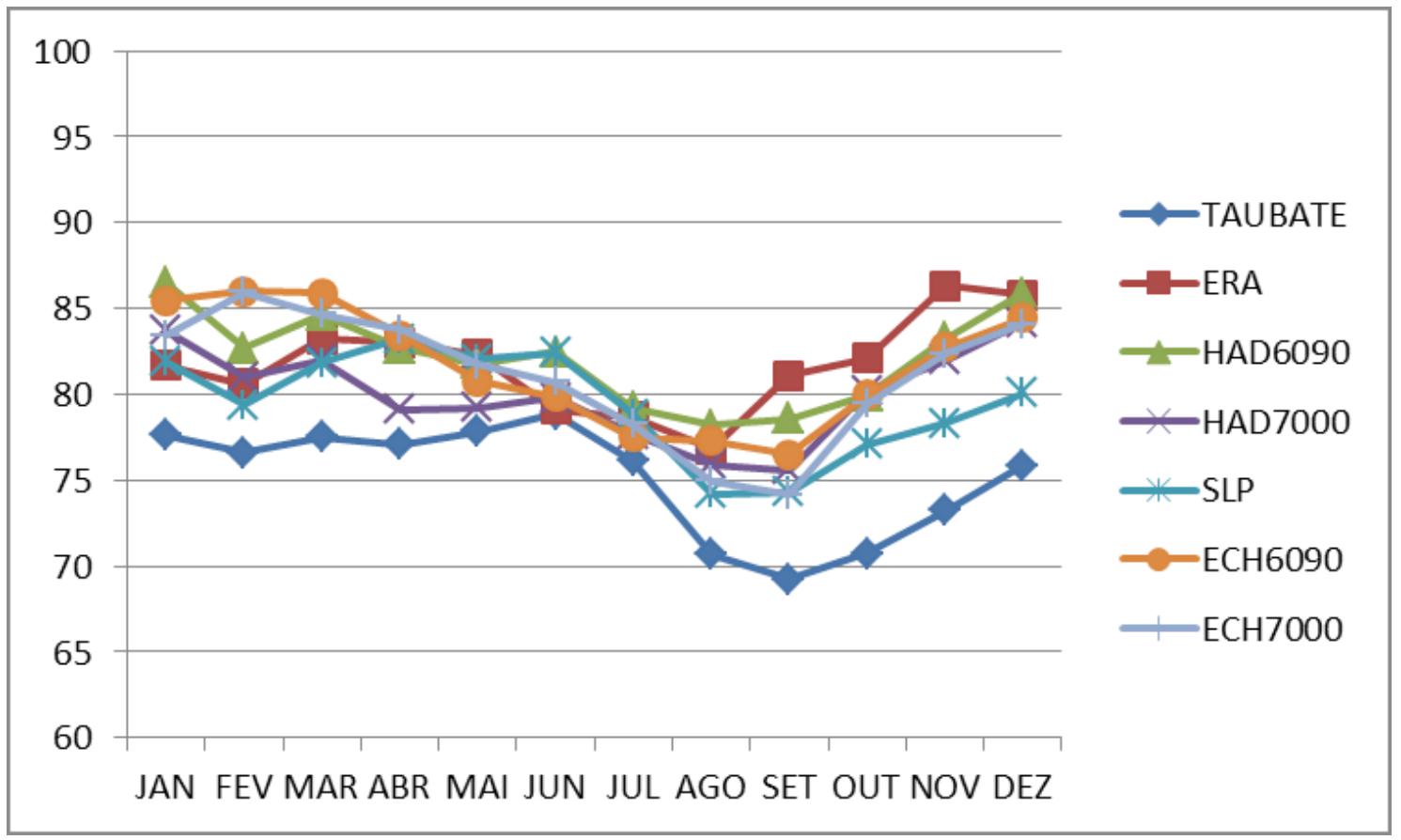

Figura 8. Comparação entre UR médias mensais observadas (estações de Taubaté e São Luís do Paraitinga - SLP) e simuladas para clima atual e futuro (ERA-Interim, HadCM3 e ECHAM5). Fonte: Ynoue et al. (2014).

É interessante notar que as simulações, tanto para temperatura quanto para UR, conseguem se aproximar bem dos padrões de variação anual observados nas estações meteorológicas, o que indica que são adequadamente representativas do clima real.

Considerando-se as médias anuais, como pode ser observado na Tabela 2, as simulações indicam um aumento de $3^{\circ} \mathrm{C}$ na temperatura nos dois modelos e uma diminuição da UR de 1\% segundo o ECHAM5 e 2\% segundo o HadCM3. Nota-se, portanto que as mudanças futuras previstas para temperatura são bem mais significativas do que as esperadas para UR. 
Tabela 2. Diferenças entre o clima futuro e o clima presente para os modelos ECHAM5 e HADCM3. Fonte: Ynoue et al. (2014).

\begin{tabular}{|lcc|}
\hline & Anual \\
\hline & ECHAM5 & HADCM3 \\
\hline T média $\left({ }^{\circ} \mathrm{C}\right)$ & 3 & 3 \\
T máxima $\left({ }^{\circ} \mathrm{C}\right)$ & 3 & 3 \\
T mínima $\left({ }^{\circ} \mathrm{C}\right)$ & 3 & 3 \\
UR média $(\%)$ & -1 & -2 \\
Velocidade do vento média $\left(\mathrm{m} \mathrm{s}^{-1}\right)$ & 0 & 0 \\
Precipitação média $\left(\mathrm{mm} \mathrm{mês}^{-1}\right)$ & 5 & 4 \\
\hline
\end{tabular}

Além das variações das médias anuais, é interessante observar a diferença entre as médias sazonais de temperatura e UR no clima atual e futuro (Tabela 3).

Tabela 3. Diferenças sazonais entre o clima futuro e o presente. Fonte: Ynoue et al. (2014).

\begin{tabular}{|lcccccccc|}
\hline & \multicolumn{3}{c}{ ECHAM5 } & \multicolumn{5}{c|}{ HADCM3 } \\
\hline & VERÃo & OUTONO & INVERNo & $\begin{array}{c}\text { PRIMAVE } \\
\text { RA }\end{array}$ & VERÃo & OUTONO & INVERNO & $\begin{array}{c}\text { PRIMAVE } \\
\text { RA }\end{array}$ \\
\hline T média $\left({ }^{\circ} \mathrm{C}\right)$ & 3 & 3 & 3 & 4 & 3 & 3 & 4 & 3 \\
T máxima $\left({ }^{\circ} \mathrm{C}\right)$ & 3 & 3 & 4 & 4 & 3 & 3 & 4 & 3 \\
T mínima $\left({ }^{\circ} \mathrm{C}\right)$ & 3 & 3 & 4 & 4 & 3 & 3 & 3 & 3 \\
UR média $(\%)$ & -1 & 0 & 0 & -1 & -2 & -3 & -2 & -1 \\
$\begin{array}{l}\text { Velocidade do vento } \\
\text { média }\left(\mathrm{m} \text { s }^{-1} \text { ) }\right.\end{array}$ & 0 & 0 & 0 & 0 & 0 & 0 & 0 & 0 \\
$\begin{array}{l}\text { Precipitação média } \\
\text { (mm mês }{ }^{-1} \text { ) }\end{array}$ & 13 & -2 & 2 & 8 & 1 & -1 & 3 & 14 \\
\hline
\end{tabular}

Nota-se que a temperatura média varia sempre em $3^{\circ} \mathrm{C}$ do clima presente para o clima futuro, exceto no caso da primavera com o ECHAM5 e do inverno com o HADCM3, nos dois casos a variação é de $4^{\circ} \mathrm{C}$. Também é interessante observar novamente que as diferenças entre UR presente e UR futura é pouco relevante 


\subsection{Biodeterioração}

Conforme foi antecipado no começo dessa Introdução, a preocupação com a exacerbação potencial de processos de degradação do patrimônio cultural material associada com as mudanças climáticas cresceu de forma expressiva, nos últimos anos, e se tornou uma temática de investigação bastante importante no âmbito das pesquisas sobre os bens culturais. Brimblecombe et al. (2006), Brimblecombe \& Grossi (2007) e Sabbioni et al. (2007) são alguns dos autores que contribuíram para dar destaque a essa questão, evidenciando quais os âmbitos que podem apresentar esse tipo de risco. Entre eles, já foram enumerados a erosão física e química associada com as precipitações e/ou aumento de poluentes químicos no ar, como $\mathrm{SO}_{2}$; a eflorescência de sais solúveis em paredes de materiais porosos; os desgastes mecânicos a ciclos de umidificação/desumidificação ou aquecimento/congelamento - sem contar com os desastres de grandes proporções, como enchentes, deslizamentos, incêndios relacionados com incidência de raios, também decorrentes de alterações climáticas. É significativo, nesse contexto, esforços que foram devotados para quantificar as projeções de variação do risco de impacto e mapeá-las numa escala espaço-temporal, com produtos parecidos com aquele mostrado na Figura 9.

Dentre os mecanismos de degradação que foram, e estão sendo, considerados, importância apreciável é dada aos de biodeterioração. Merecem menção estudos sobre impactos ligados à alterações dos ciclos de vida de insetos em ambientes indoor (BRIMBLECOMBE \& LANKESTER, 2012), que já mostram, com dados do período de 2000 a 2012, na Inglaterra, o provável aumento de determinados insetos deletérios para o patrimônio material devido ao aumento na temperatura. Em termos gerais, a questão dos microrganismos e sua associação com as mudanças climáticas, é tratada numa revisão de Viles \& Cutler (2012), que ao mesmo tempo destacam a complexidade de um tema que envolve inúmeros aspectos - inclusive a variação na disponibilidade de nutrientes e a influência provável da qualidade do ar - e a carência de estudos desse tipo focados nos bens culturais. Segundo esses autores, as perspectivas, para as regiões com previsão de acréscimos na temperatura e nas precipitações, são de um aumento de processos mediados por organismos vivos (biologically mediated processes), ainda que entre esses processos seja preciso incluir não somente a biodeterioração, mas também situações de bioproteção. 


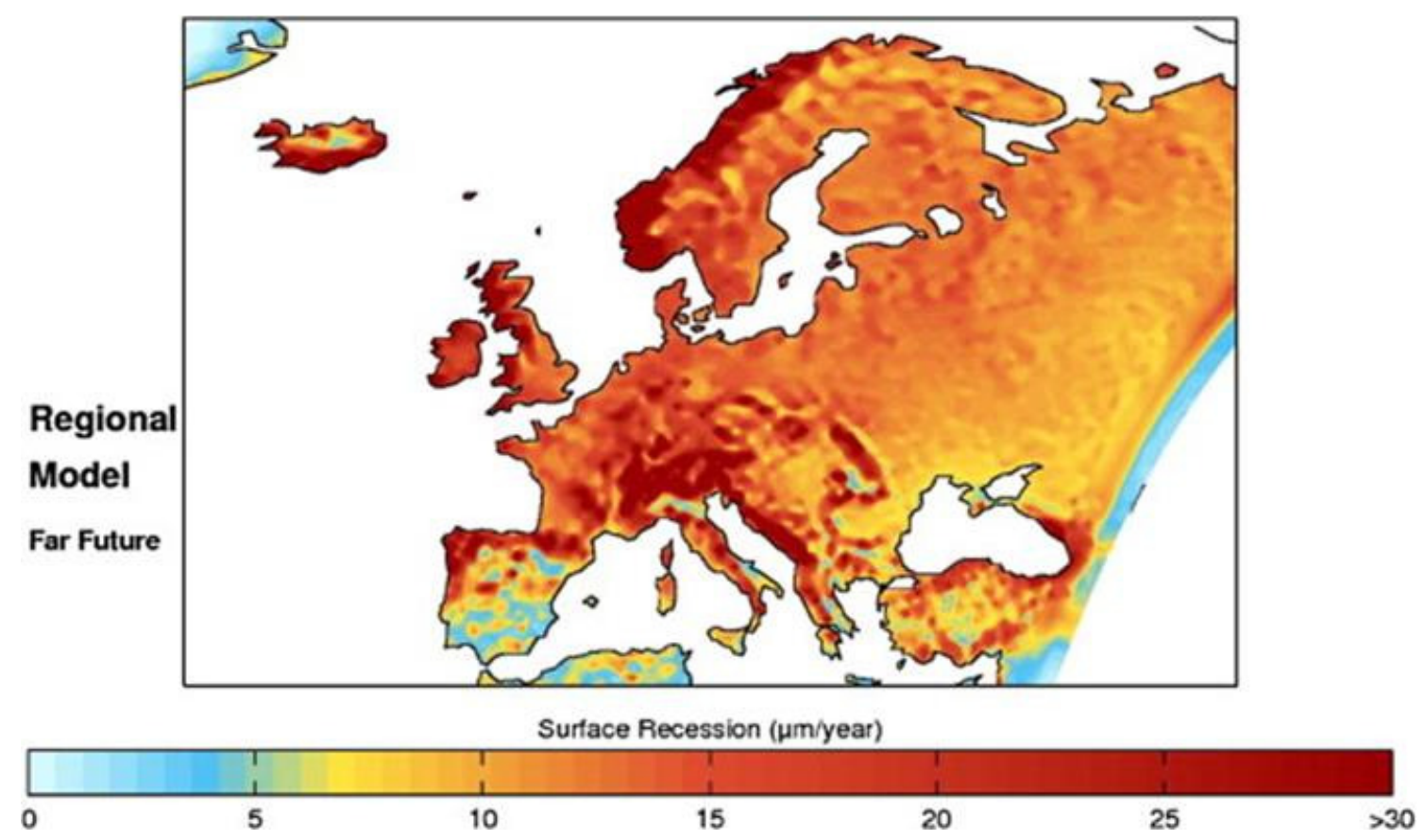

Figura 9. Mapa do aumento do risco desgaste material (recession) de superfícies de materiais a base de carbonatos (p. ex. mármore) frente a mudanças no clima projetadas com base no cenário A2 por meio de projeções para o clima de 2079-2099 realizadas com o modelo HadRM3. Fonte: Bonazza et al. (2009).

\subsubsection{Mecanismos de biodeterioração}

Os termos biodeterioração e biodegradação indicam o conjunto de processos pelos quais um substrato orgânico ou inorgânico sofre alterações e perde estabilidade em razão das atividades vitais de organismos como insetos, fungos, bactérias e algas. Essas transformações englobam mecanismos químicos ou físicos, dependendo da ocorrência (ou não) de mudanças na estrutura molecular dos constituintes do substrato. Geralmente esses dois mecanismos ocorrem simultaneamente e, dependendo dos agentes de biodegradação/biodeterioração, do tipo de substrato e das condições ambientais, um deles pode prevalecer.

Biodeterioração e biodegradação são termos equivalentes do ponto de vista da natureza processos físico-químicos envolvidos. Entretanto, eles remetem a implicações e consequências de diferentes ordens. O termo biodeterioração, normalmente, é usado para referir-se a processos pelos quais há uma redução do valor (valor funcional, estético e econômico) de um determinado material, tendo portanto uma conotação 
negativa. De acordo com Hueck (2001, p. 6), biodeterioração é "qualquer alteração indesejável das propriedades de um material, causada por atividades vitais de organismos". Já, a expressão biodegradação denota essencialmente um julgamento neutro ou até positivo referindo-se, por exemplo, a processos de ciclagem de materiais, fundamentais para os ciclos biogeoquímicos, ou a decomposição de resíduos antropogênicos potencialmente danosos aos ecossistemas (EGGINS; OXLEY, 2001).

Podemos dividir os processos de biodeterioração em três grandes grupos: os mecanismos físicos, os mecanismos químicos e os danos estéticos. Processos exclusivamente físicos são aqueles que causam abrasão mecânica, fratura e ruptura do substrato devido às atividades de movimento ou crescimento dos organismos. Os fragmentos produzidos têm a mesma composição química que os materiais originais, e são facilmente retirados do substrato, devido à pressão, durante o crescimento dos organismos e das suas partes, como por exemplo, as raízes das plantas. Além disso, quando o substrato é reduzido a pequenos fragmentos proporciona uma superfície maior para outros fatores de deterioração.

Em geral em casos de deterioração por processos mecânicos, o dano causado por organismos (como plantas, pássaros e insetos, só para citar os mais comuns, de dimensões expressivas) é maior do que o causado por micro-organismos (bactérias, fungos). Rupturas das tubulações subterrâneas causadas por raízes de árvores e a expansão de massas microbianas entre camadas de rocha que causa rachaduras na superfície são exemplos de danos puramente mecânicos causados por organismos e micro-organismos (ALSOPP, 2004 ; CANEVA et al., 1991).

Processos químicos envolvem a decomposição ou transformação do substrato por atividade química de organismos. Bactérias, algas e fungos têm uma razão superfície/volume muito grande comparada à de animais e plantas, o que permite uma rápida difusão de metabólitos entre as células e o ambiente circundante.

Os processos químicos podem ser, de forma geral, divididos em dois tipos: assimilatórios e dissimilatórios. No primeiro o organismo usa o material como fonte de energia, exemplos são enzimas microbianas decompondo celulose e larvas de insetos consumindo frutas armazenadas. No segundo, o material sofre dano mas não como resultado direto do influxo de nutrientes pelo organismo, mas da excreção de resíduos ou produtos intermediários do metabolismo incluindo ácidos, agentes complexantes e 
pigmentos. Os processos dissimilatórios estão fortemente associados à biodeterioração assimilatória e à formação de biofilmes. (ALSOPP, 2004; CANEVA et al., 1991)

A biodeterioração química desenvolve-se de diferentes formas (CANEVA et al., 1991):

- Acidólise: os ácidos agem diretamente nas moléculas do substrato, gerando a formação de sais. Durante os processos metabólicos, os agentes de biodeterioração liberam ácidos orgânicos e inorgânicos em grande quantidade.

- Complexação: os micro-organismos excretam ácidos orgânicos e fenóis que promovem a complexação (ou quelação) de certos metais tornando disponíveis elementos como ferro, potássio, manganês e o cálcio, por meio da solubilização dos materiais que os contêm.

- Deterioração por álcalis: durante processos metabólicos, compostos básicos (como amônia e carbonato de sódio) podem ser liberados. Essas bases podem reagir com algumas moléculas do substrato e geralmente aumenta o $\mathrm{pH}$ favorecendo o desenvolvimento de micro-organismos basófilos.

- Troca iônica: micro-organismos podem absorver cátions metálicos para sua nutrição mediante processo de troca iônica, um exemplo desse fenômeno é a transformação da mica em vermiculita por fungos (íons $\mathrm{K}^{+}$são trocados por íons $\mathrm{Na}^{+}$).

- Deterioração enzimática: enzimas são moléculas proteicas com atividade altamente específica. Para que elas possam exercer sua função catalítica elas têm que "combinar" com as moléculas do substrato. Existem as endoenzimas, que não são excretadas das células onde são produzidas e as exoenzimas (ou enzimas extracelulares), que são excretadas. As enzimas extracelulares cumprem um importante papel nos processos de biodeterioração. A principal função de uma exoenzima é transformas as moléculas complexas presentes no substrato (como proteínas, celulose, lignina) em moléculas mais simples e solúveis em água, de modo a permitir que os nutrientes entrem na célula.

- $\quad$ Produção de pigmentos: Muitos micro-organismos produzem pigmentos de diferentes cores durante seu desenvolvimento. A liberação de pigmentos ou a presença de micro-organismos que contenham pigmentos provoca o surgimento de "manchas" nos materiais. Os pigmentos liberados são característicos de cada espécie, porém, a cor das manchas depende de muitas coisas além da composição química dos 
pigmentos, como a composição química do material atacado, o $\mathrm{pH}$ do meio, a presença de outras espécies de micro-organismos.

A biodeterioração estética diz respeito a danos não relacionados com alterações físicas e químicas do material em questão. A alteração estética ocorre por conta da presença de um organismo, seu excremento ou produto metabólico. Nesse caso, o micro-organismo faz com que o material perca valor apenas pela alteração na aparência. Um exemplo comum é o mofo crescendo em diferentes substratos, ou seja, um microorganismo que não decompõe o substrato para obtenção de nutrientes, nem causa alterações estruturais no substrato com seu crescimento. Obviamente, a fronteira entre danos estéticos e danos estruturais não é tão nítida. A dificuldade em determiná-la advém de questões como o fato de que mesmo quando os micro-organismos não causam decomposição direta no substrato seu metabolismo produz $\mathrm{CO}_{2}$ da respiração o que pode induzir alterações (ALSOPP, 2004; CANEVA et al., 1991).

Tanto as alterações estruturais (física e químicas) quando as estéticas podem causar limitações funcionais ao material. A viga de uma edificação que sofre ataque de enzimas pode perder a capacidade de sustentação, uma pintura que tem alteração em sua coloração por conta de crescimento de mofo sofrerá limitações em sua função artística, por assim dizer.

\subsubsection{Biodeterioração de materiais inorgânicos}

Mohammadi e Krumbein (2008) estudaram a deterioração físico-química causada por micro-organismos em materiais de pedra dos monumentos de Persépolis (atual Irã). Biofilmes e líquens presentes nas superfícies das rochas foram analisados por microscópio óptico. As alterações da superfície das rochas, bem como os biofilmes presentes foram analisadas mediante microesteroscópio de dissecação. As características e estruturas dos biofilmes foram estudas por microscópio eletrônico de varredura. Também foram realizadas fotomicrografias de finas amostras de mármore e calcário, a fim de demonstrar as principais feições das formações biogênicas de corrosão e outras estruturas de desgaste na superfície das rochas.

Aloise et al. (2013) estudaram a biodeterioração de materiais de pedra coletados no sítio arqueológico submarino de Baia (Nápoles, Itália). Foi verificada significativa 
colonização biológica na superfície de todas as amostras. Os materiais de mármore e pedra calcária apresentaram algum tipo de biodeterioração em $90 \%$ da superfície. O estudo demostra a correlação entre o tipo de biodeterioração e o material que compõem a pedra. Os materiais calcários (mármore e pedra calcária) a principal causa de biodeterioração está relacionada com a atividade de esponjas que provocam corrosão e microfuros. Nos tijolos e ignimbritos os principais organismos responsáveis por biodeterioração são as espécies incrustadas como serpulídeos e briozoários, que colonizam a superfície produzindo deposições calcarias esbranquiçadas acarretando um dano estético no substrato. Nesses substratos também verificou-se maior ataque por algas, em comparação aos materiais calcários.

\subsubsection{Biodeterioração de Materiais Orgânicos}

Os bens culturais compostos de materiais orgânicos são mais susceptíveis a biodeterioração do que os compostos de materiais inorgânicos. A biodeterioração ocorrerá assim que as condições microclimáticas forem favoráveis ao crescimento biológico. Essas condições são comuns em ambientes indoor: UR de $65 \%$, juntamente a temperatura acima de $20^{\circ} \mathrm{C}$ já é suficiente para provocar crescimento de microorganismos. Baseando-se em sua composição, para fins de classificação, os materiais orgânicos poderiam ser divididos (i) origem vegetal (ii) origem animal (CANEVA et. al, 1991).

Muitos bens culturais são feitos de materiais de origem animal: pergaminhos, materiais de couro, de lã, de seda. Nesse caso, a biodeterioração está relacionada com a deterioração de componentes como proteínas, aminoácidos ou componentes parcialmente polimerizados. Proteínas são polímeros de alto peso molecular compostos de cerca de 22 aminoácidos ligados por ligações peptídicas formando uma cadeia. (CANEVA et al., 1991)

Troiano et al. (2014) avaliaram o risco para conservação de manuscritos de pergaminho do século XVI os quais exibiam uma descoloração marrom, supostamente causada por micro-organismos. Análises microscópicas e ensaios de ATP demonstram um baixo nível de contaminação, indicando que a descoloração não estaria relacionada com colonização microbiana ativa. Por outro lado, uma abordagem molecular 
independente de cultura foi adotada para caracterizar de forma completa comunidades associadas à superfície para encontrar agentes de biodeterioração que pudessem crescer sob condições termo higrométricas apropriadas. Agentes de biodeterioração potenciais relacionados com humanos foram encontrados, indicando que a necessidade de melhor controle do ambiente de conservação e de melhoras no manuseio. Além disso análises das cargas de micro-organismo aéreos, assim como medidas termo higrométricas, indicaram que o local de armazenamento dos pergaminhos não é adequado para prevenir sua biodeterioração.

Os principais componentes dos materiais de origem vegetal são a celulose, a lignina e a hemicelulose. Trata-se de biopolímeros, ou seja, de moléculas de elevada massa molecular em que estruturas básicas mais simples (monômeros) se repetem sucessivamente com maior ou menor regularidade e numa arquitetura mais ou menos complexa. (FENGEL \& WEGENER, 1989; WIEDENHOEFT \& MILLER, 2005)

A celulose consiste de um polissacarídio linear composto de unidades D-glucose ligadas em uma longa cadeia por ligações glicosídicas. É um dos componentes da parede celular de todos os tecidos de plantas, estruturais e condutivos. A porcentagem de celulose varia de acordo com a espécie do vegetal, e do tipo de tecido envolvido, tendo uma presença maior em materiais feitos de dicotiledôneas herbáceas e menor em materiais derivados de madeira de coníferas. A biodegradação da celulose ocorre por meio da produção de um sistema de diversas enzimas intracelulares e extracelulares chamado complexo celulase. Essas enzimas decompõem a celulose em glucose visando sua digestão e, portanto, a obtenção de energia (CANEVA et al., 1991).

A lignina é uma macromolécula tridimensional muito complexa e sem uma estrutura primária definida, mas onde predominam unidades monoméricas que compreendem o anel aromático e grupos alcoólicos. Tais unidades estão interligadas por ligações carbono-carbono e carbono-oxigênio não facilmente hidrolisáveis. A lignina é parte essencial das fibras lenhosas, a sua porcentagem nos sistemas lenhosos de gymnospermae e angiospermae varia de 15 a 36\%. O teor de lignina nos materiais de origem vegetal varia de acordo com a procedência do material bruto e dos tratamentos químico-físicos usados na manufatura. Em madeiras de construção, por exemplo, a porcentagem de lignina depende da espécie arbórea de origem e da parte da planta usada; em papel isso depende dos tratamentos de deslignificação empregados. A lignina é resistente à degradação para maioria dos micro-organismos, apenas alguns fungos e 
algumas bactérias são capazes de degradá-la. Os mais importantes e mais conhecidos degradadores de lignina são os fungos de podridão branca.

Hemiceluloses são polissacarídios solúveis em álcalis associados com a celulose na parede celular da planta. São compostas por $\beta$-D glucanas, substâncias pécticas e diversos heteropolissacarídeos. (CANEVA et al., 1991). A maioria das bactérias e fungos podem hidrolisar hemicelulose por meio de produção de enzimas hemicelulase.

Rojas et. al. (2012) estudou a presença de fungos em prédios históricos em Havana, e a contaminação dos bens alocados nessas edificações. Foram isolados microorganismos de diversos substratos, incluindo papel. Os gêneros mais comuns encontrados foram Aspergillus, Penicillium e Cladosporium. A maioria das cepas estudadas demonstrou capacidade de produzir celulase (principalmente do gênero Aspergillus) e ácidos. Também foi verificada a produção de pigmentos por alguns Aspergillus (pigmentos de cor âmbar) e em alguns Penicillium (pigmentos de cor amarela).

Sabe-se que entre $60 \%$ e $90 \%$ do volume das células da madeira tem função de sustentação mecânica e/ou condução. Essas células perdem seu protoplasto na maturidade funcional, tornando-se células mortas. Portanto, a maior parte das células maduras da madeira é composta apenas da parede celular e do lume que é o espaço vazio deixado pelo protoplasto.

Vale destacar que a composição química da parede celular varia significativamente entre os dois grandes grupos de vegetais produtores de madeira. As coníferas (softwoods em inglês) costumam ter mais celulose $(42 \pm 2 \%)$ e lignina (28 \pm $2 \%$ ) e menos hemicelulose (27 $\pm 2 \%$ ) do que as folhosas (hardwoods em inglês) (45 \pm $2 \%$ de celulose, $20 \pm 4 \%$ de lignina e $30 \pm 5 \%$ de hemicelulose) (KLOCK et al., 2005; WIEDENHOEFT \& MILLER, 2005).

Células lignificadas, como é o caso das células de madeira, apresentam normalmente os seguintes elementos estruturais: lamela média, parede primária e parede secundária, sendo que a parede secundária pode ainda ser dividida em cama S1 (ou camada de transição), S2 e S3 (ou parede terciária) (DECHAMPS \& WRIGHT, 1997, KLOCK et al., 2005). 


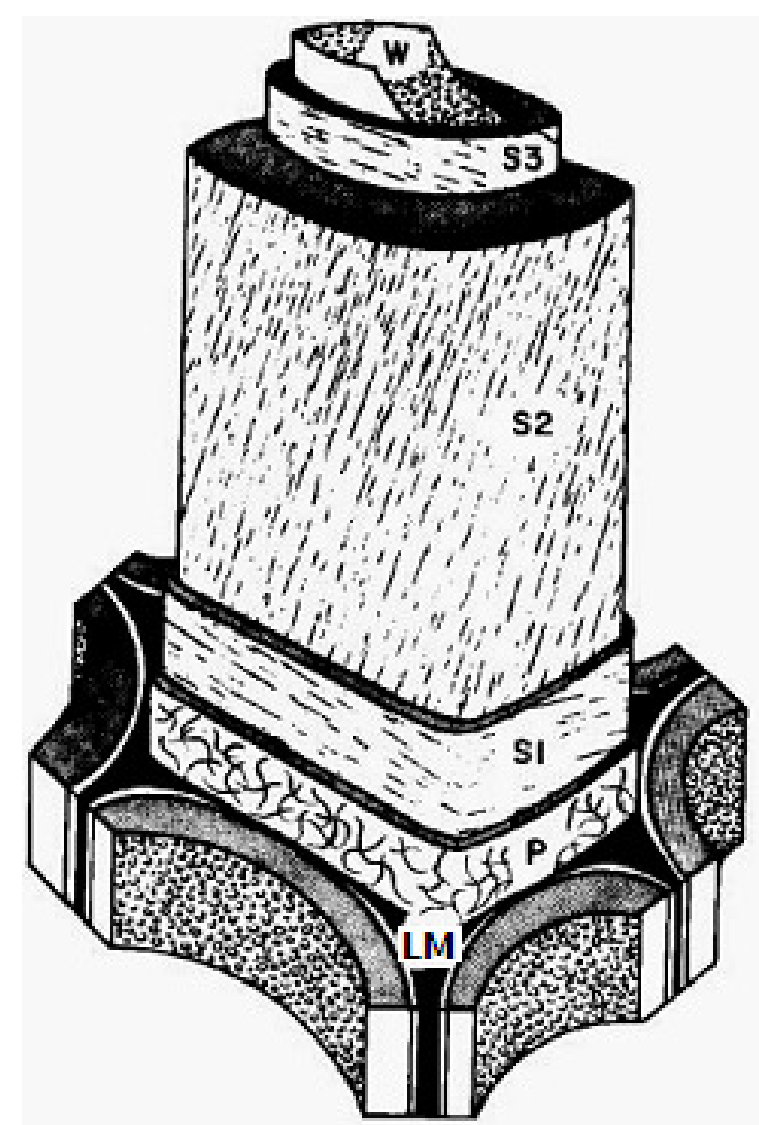

Figura 10. Modelo estrutura celular da madeira. $\mathrm{LM}=$ lamela média, $\mathrm{P}=$ parede primária, $\mathrm{S} 1=$ camada 1 da parede secundária, $\mathrm{S} 2$ = camada 2 da parede secundária, $\mathrm{S} 3$ = camada 3 da parede secundária ou parede terciária segundo alguns autores, $\mathrm{W}=$ camada verrugosa (warts). Fonte: Klock et al. (2005).

Em termos de biodegradação, no caso da madeira, além da ação de insetos sociais da ordem dos isópteros (cupins), destaca-se a agressão produzida por microrganismos xilófagos e, em particular, fungos capazes de produzir enzimas extracelulares de degradação dos diferentes componentes da madeira (BRAZOLIN et al., 2002).

Em condições aeróbias, os fungos xilófagos podem apresentar três padrões ou tipos de degradação na madeira atacada: podridão branca, castanha ou branda (white, browne soft rot em inglês) com base nas enzimas produzidas e na classificação de cor e estrutura de resíduos de madeira depois da degradação (BLANCHETTE, 1998, ERIKSSON et al., 1990).

Fungos de podridão branca são comumente encontrados em ecossistemas florestais e têm a capacidade de produzir enzimas que degradam todos os três componentes da parede celular. Os tipos de enzimas produzidos e o número de sequências de produção determinam a quantidade e a extensão de sua degradação 
(BLANCHETTE, 1991). Para os organismos xilófagos, a celulose constitui o nutriente mais nobre, pois sua hidrólise determina a produção de açucares que representam importantes fontes de energia para o microrganismo, quando digeridos. No caso de fungos lignolíticos, como os que propiciam a podridão branca, a produção de enzimas que quebram a lignina representa um meio para a abertura de caminhos que levem a atingir as reservas de celulose presentes na madeira (KIRK et. al., 1976). A maioria dos fungos de podridão branca é do filo Basidiomycota, portanto essa divisão tem muita importância para estudos sobre degradação e deterioração de materiais de madeira (ERIKSSON et al., 1990).

Fungos de podridão castanha são geralmente degradantes de madeira de gimnospermas (as coníferas, como os pinheiros), muito usadas como madeiras industriais (ZABEL \& MORRELL, 1992). Eles degradam preferencialmente os componentes polissacarídeos da madeira (celulose e hemicelulose).

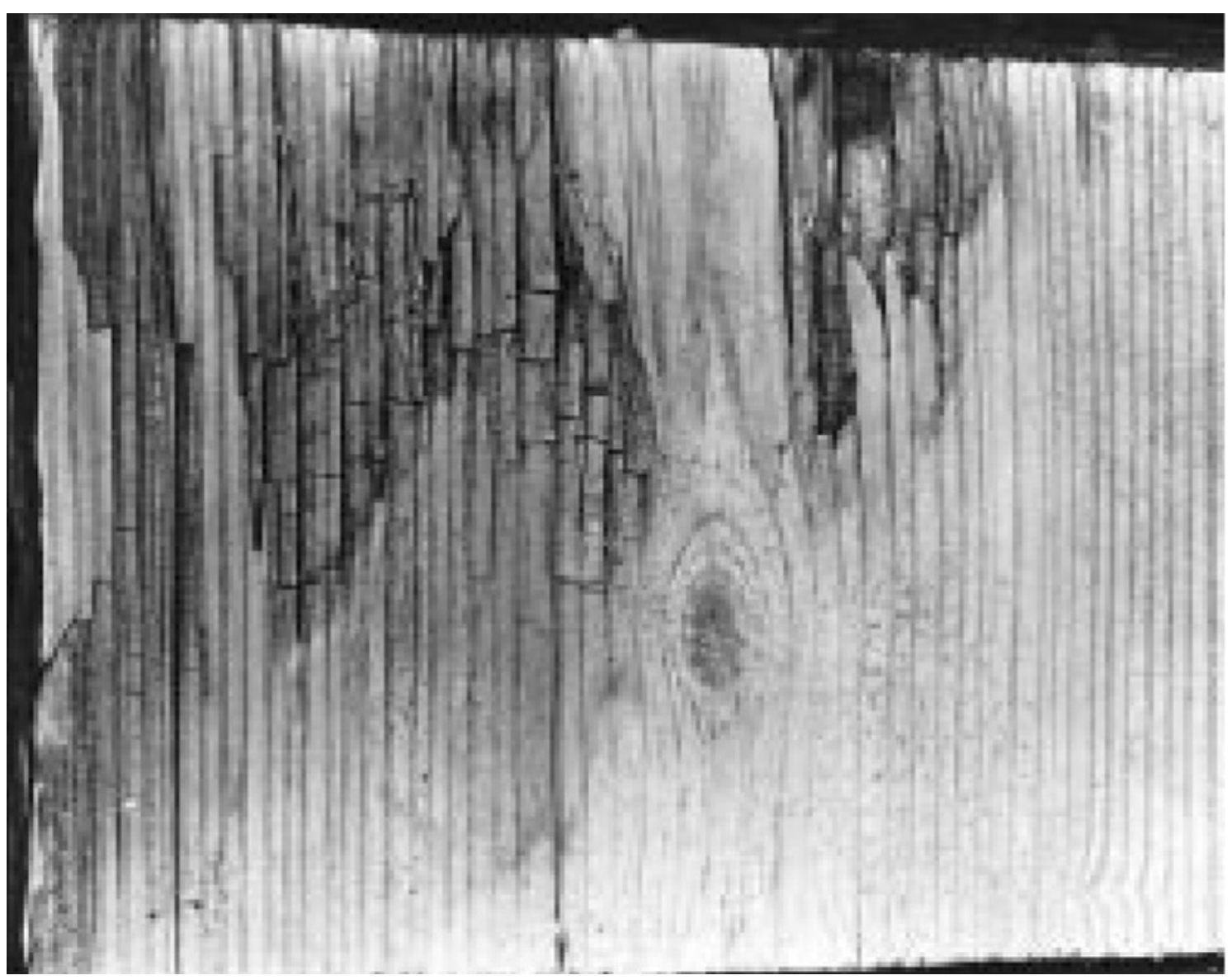

Figura 11. Imagem de madeira de pinho com podridão castanha. Fonte: Wiedenhoeft e Miller (2005). 
Os fungos de podridão branda produzem buracos em espiral dentro da parede secundária das células de madeira seguindo a orientação de microfibrilas de celulose (DANIEL \& NILSSON, 1998). Em seções transversais de madeira pode-se observar buracos de diferentes tamanhos nas paredes laterais, enquanto que nas seções radiais ou tangenciais são observadas cavidades alongadas. Este tipo de decomposição ocorre principalmente quando a madeira fica exposta a umidade excessiva, mas também pode ocorrer em ambientes secos (BLANCHETTE, 1998). Fungos da podridão branda são frequentemente encontrados em ambientes não favoráveis para o crescimento das espécies que produzem podridão branca e castanha, possuem enzimas que degradam a celulose e hemicelulose, ao passo que a lignina é ligeiramente modificada (BUCHER et al., 2004). Nos estágios avançados de decaimento, a madeira torna-se frágil e amarronzada.

Diversos estudos foram dedicados a avaliar o risco de biodeterioração de bens culturais à base de madeira. Brazolin et al. (2002) apresentaram um diagnóstico da presença de fungos e cupins no Museu da Arte Sacra de Salvador - BA. Foram identificadas 3 tipos de cupins no museu: cupins-de-madeira-seca (família Kalotermitidae), cupins de solo (três espécies encontradas: Coptotermitinae gestroi $e$ Amitermes sp., família Termitidae, e Heterotermescf. tenuis) e cupins arborícolas (Nasutitermes corniger, família Termitidae).

Também foi observada a presença de fungos degradadores da madeira, entretanto, sua presença foi restrita às partes da edificação exposta às chuvas, como batentes de portas e janelas; e áreas molháveis internas. Nas partes estruturais do telhado, a presença dos cupins foi mais importante do que a dos fungos. Foram encontrados fungos das divisões Eumycota e Basidiomycotina, causadores de podridão castanha e branca. O estudo também investigou formas de controle desses organismos, como a utilização de produtos difusíveis a base de boro ou flúor, bastante eficientes e menos tóxicos (BRAZOLIN et al., 2002).

Rojas avaliou a presença e atividade de fungos isolados em amostras de madeiras de construções históricas em Havana (Cuba). Foram principalmente identificados fungos dos gêneros Aspergilluse Cladosporium. Na maioria das cepas foi verificada capacidade de produção de celulase. As cepas do gênero Cladosporium exibiram capacidade de produção de polifenoloxidadese. Algumas cepas Aspergillus produziram pigmentos amarelos, avermelhados e marrons claro. 
Ortiz et al. (2014) estudaram a biodeterioração das igrejas históricas de madeira da ilha de Chiloé no Chile. Foram identificados os padrões de deterioração presentes nas igrejas assim como os fungos endófitos causadores dos processos de biodeterioração. Também foram identificadas as espécies das madeiras coletadas.

Análises com microscópio eletrônico de varredura possibilitaram identificar as espécies das madeiras deterioradas assim como os padrões de degradação. As amostras foram identificadas como pertencentes a cinco espécies de árvores: Fitzroya cupressoides, Pilgerodendron uviferum, Nothofagus dombeyi, Eucryphia cordifoliae e Drimys winteri.

Verificou-se a presença de podridão branca e castanha em todas as igrejas. A deterioração era frequentemente extensiva e estavam em estados avançados. Também foi verificada podridão branda em algumas madeiras exteriores feitas de Fitzroya cupressoidese e Pilgerodendron uviferum que são árvores consideradas resistentes a deterioração.

Os fungos endófitos isolados das amostras coletadas foram identificados mediantes análise molecular, verificando-se a presença de vinte e nove fungos Basidiomycota e dezoito Ascomycota. Dentre os fungos identificados, dois gêneros e seis espécies foram relatados pela primeira vez no Chile.

Pornou e Bogomolova (2008) estudaram os ataques de micro-organismos (principalmente fungos) sobre madeiras com alto teor de umidade encontradas em escavações do assentamento pré-histórico de Dispilio.

Dezessete espécies de fungos foram identificas nas culturas isoladas das amostras de madeira, sendo uma espécie de Zygomycete, 13 espécies de Hyphomycetes, uma espécie de Ascomycete, uma espécie de Agnomycete e uma espécie de levedura. Apesar do alto nível de umidade das amostras, as espécies de fungos identificadas eram típicas de ambientes terrestres. Nenhum dos fungos encontrados são considerados especialistas em deterioração de madeira, podendo-se inferir que eles poderiam causar dano à madeira apenas sob condições específicas. Também foram encontradas bactérias do tipo cocos e bastonetes com grande crescimento.

As observações com os microscópios óptico e eletrônico sobre a madeira revelaram intensa deterioração da madeira, causada por fungos e bactérias. Foram observadas cavidades cônicas e penetração hifal nas paredes celulares, além de padrões de deterioração por erosão bacteriana e outros tipos de ataques de bactérias. 
Fazio et al. (2010) caracterizaram a biodeterioração de escultura jesuítica sulamericana de madeira abrigada no Museu de Ciências naturais em La Plata, Argentina. Três pequenos segmentos de amostras de madeira foram cortados assepticamente e imersos em etanol:água (7:3), secos em papel filme estéril e esterilizada por chama para prevenir infecção por fungos oportunistas. Posteriormente os segmentos foram inoculados em meio de cultura de extrato de malta contendo extrato de malta Difco $(2 \%)$ e ágar $(2 \%)$ com antibióticos adicionados. As placas foram incubadas a $28^{\circ} \mathrm{C}$ e pontas de hifas eram transferidas periodicamente transferidas outras placas a fim de obter cultura pura.

Após oito a dez dias as cepas puras foram examinadas sob microscópio óptico e as espécies fúngicas foram identificadas com apoio da literatura taxonômica. Para identificação de madeiras, seções foram fixadas em aldeído:etanol:ácido acético, desidratadas e embebidas em parafina e cera, seccionada, tingida e observada em microscópio óptico seguindo técnicas histológicas padrão. Para as observações em MEV, seções de madeira foram hidratadas, cortadas e montadas em bases de alumínio e cobertas com ouro e então examinadas no microscópio. Também foram realizados diversos ensaios para medir as atividades enzimáticas.

Baseando-se na anatomia das amostras observadas a madeira foi identificada como Cedra fissilis. Nas análises por MEV foram observadas evidências de deterioração por fungos. Verificou-se, por exemplo, cavidades nas paredes celulares secundárias típicas de podridão branda. Foram identificadas duas espécies de fungos no microscópio óptico, o Nigrospora sphaerica e o Chaethomium globosum.

Como os fungos identificados produziram xilanases, celulases e pectinases, infere-se que o padrão de degradação observada pode ser atribuída principalmente a elas. C. globosum foi previamente descrito como um fungo de podridão branda, enquanto $N$. sphaerica foi mencionado antes como fitopatogênico. A interferência aparente neutra entre as duas espécies somada às atividades enzimáticas complementares (atividades pectinolítica em $N$. sphaerica), indicam que ambos os fungos contribuem para a degradação, como indicado pela destruição das várias zonas da madeira, incluindo lamela média, que não são atacadas por uma podridão branda.

Irbe et al. (2012) estudaram a biodeterioração das estruturas externas de madeira do Museu Etnográfico à Ceu Aberto da Letônia e dos edifícios de madeira sacra do leste da Letônia. Foram identificados fungos do filo Basidiomycota, Ascomycota e Protozoa. 
Os gêneros mais encontrados foram Antrodia, Gloeophyllum, Athelia, Hyphoderma, Hyphodontia, Pharenochaete, Postia e Botryobasidium.

Verificou-se que as estruturas dos monumentos mais afetadas pela biodeterioração eram telhados, paredes e cercas. Entre os fungos encontrados observouse uma predominância das espécies de podridão branca.

\subsubsection{Biodeterioração de Materiais Compostos}

Alguns objetos artísticos são compostos por tanto por materiais orgânicos quanto inorgânicos, de maneira que são classificados como materiais compostos. É o caso das pinturas que são constituídas de um suporte (madeira, rocha, pergaminho) e da camada de tinta (que pode ter diversas composições químicas). (CANEVA et al., 1991).

Lopés-Miras et al. (2013) investigaram a biodeterioração de pintura a óleo em tela "Virgem de Guadalupe" exposta no convento de San Antón (Granada, Espanha).

Foram realizadas análises moleculares para identificação dos micro-organismos. Foram identificadas espécies de bactérias dos gêneros Stenotrophomonas, Aeromonas, Pseudoalteronomas pertencentes ao filo Proteobacteria; espécies dos gêneros Brevi bacterium, Mycobacterium e Arthrobacter pertencentes ao filo Actinobacteria e espécies dos gêneros Bacillus, Paenisporosarcina, Paucisalibacillus e Virgibacillus do filo Firmicutes. Quanto aos fungos, foram identificados gêneros do Candidia, Pichia, Alternaria, Penicillium, Eurotium, Ulocladium e Emericella do filo Ascomycota; e o gênero Mucor, do filo Zygomycota.

Testes enzimáticos revelaram que as enzimas mais comuns relacionadas com a biodeterioração da pintura por bactérias são esterase e esterase lipase. No que diz respeito a biodeterioração por fungos as enzimas mais comuns eram esterase e N-acetilb-glucosaminidase.

Diaz-Herraiz et al. (2014) estudaram a biodeterioração dos afrescos da Tomba del Colle localizada em Chiusi, Itália. As paredes da tumba apresentam colonizações de biofilmes e bactérias que se sobrepõem sobre as pinturas na forma de coberturas esbranquiçadas de forma circular a irregular. As colônias tendem a conectar-se entre si de forma a colonizar de grandes extensões. Verificou-se que as colônias eram compostas primariamente de organismos filamentosos, depósitos de $\mathrm{CaCO}_{3}$ e 
substâncias poliméricas extracelulares. Análises moleculares revelaram que os principais grupos filogenéticos presentes nas colônias seriam os Alphaproteobacteria e Actinobacteria. Os Alphaproteobacteria representariam entre 49 e $57 \%$ das sequências de DNA em três amostras. Actinobacteria representaria entre 25 e $30 \%$ das sequências em três amostras.

\subsection{Fungos}

Os fungos são organismos eucarióticos. Podem ser pluricelulares ou unicelulares. Apresentam parede celular, normalmente composta por glucanas e quintina. Não apresentam plastos ou pigmentos fotossintéticos, possuem nutrição heterotrófica e digestão extracelular. A reprodução pode ser assexuada e/ou parasexuada e/ou sexuada. (WEBSTER \& WEBER, 2007)

\subsubsection{Morfologia dos fungos}

Os fungos apresentam, na maioria das vezes, um corpo filamentoso, chamado de micélio, que é formado por estruturas que contém protoplasma chamados de hifas. As hifas são, de forma geral, muito semelhantes em todas as espécies de fungos que as apresentam. Uma das poucas características diferenciais é a presença ou ausência de paredes divisórias (septos). Os Oomycota e os Zygomicota geralmente não apresentam septo. Nesses grupos, os núcleos estão dispostos em uma mesma massa de citoplasma, constituindo-se, portanto, células do tipo cenócito (do grego: koinos= partilhar em comum + kytos $=$ compartimento) que não apresentam divisão celular. Os Asco basidiomycota normalmente têm hifa septada, em cada segmento pode haver um ou mais núcleos. Quando as células do micélio possuem dois núcleos, diz-se que são células monocarióticas, quando há dois núcleos, a célula é denominada de célula dicariótica. Se os núcleos existentes na célula forem geneticamente iguais, o micélio será chamado de homocariótico. Já quando a célula ou micélio possui núcleos geneticamente diferentes, resultado de anastomose, chama-se micélio heterocariótico. 
Existem, porém, fungos que não se desenvolvem na forma de hifas, e sim na forma de leveduras. As leveduras ocorrem principalmente em situações em que uma penetração eficiente no substrato não é necessária, como em superfícies de plantas de plantas ou no trato digestivo de animais. A divisão assexuada das leveduras ocorre mais comumente por brotamento, mas também pode ocorrer por cissiparidade. Existem também fungos capazes de desenvolver-se tanto como micélio quanto como hifa, os chamados dimórficos e fungos que desenvolvem com características intermediárias entre hifas e leveduras. (WEBSTER \& WEBER, 2007)

\subsubsection{Nutrição dos fungos}

Os fungos, são heterótrofos, ou seja, necessitam de materiais orgânicos já forma dos que servem como fonte de energia e como constituintes celulares. Diferentemente dos animais (que ingerem o alimento e depois o digerem) obtêm seus nutrientes por meio de digestão extracelular seguida de absorção dos produtos decompostos solubilizados. A digestão extracelular ocorre mediante secreção de enzimas que degradam o substrato.(WEBSTER ; WEBER, 2007).

Os fungos vivem em estado de saprofitismo, parasitismo, simbiose (liquens) ou mutualismo. Quando saprófitos ou parasitas, podem ser saprófitos obrigatórios, que vivem apenas de matéria orgânica morta; saprófitos facultativos (ou parasitas facultativos), são capazes de viver em organismos vivos e restos orgânicos; e parasitas obrigatórios que vivem exclusivamente atacando organismos vivos. (MORAES et al., 2009 )

\subsubsection{Reprodução dos fungos}

Os fungos têm sua reprodução baseadas em dois tipos de corpúsculos: os esporos (reprodução sexuada) ou conídios (reprodução assexuada). Os esporos e os conídios, para germinar precisam de calor, umidade e o resultado desta germinação é a formação de um ou mais filamentos finos, conhecidos como hifas que formam o micélio. 
Os fungos podem realizar reprodução sexuada ou assexuada. As estruturas reprodutivas podem ser formadas isoladamente ou em grupos, neste caso, formando corpos de frutificação.

Assim, conídios podem ser formados em conidióforos isolados ou agrupados, constituindo então os conidiomas. Os esporos podem ser formados em ascomas (onde são formados os ascos) ou basidiomas (onde são formados os basídios). (MORAES et al., 2009 )

Pode-se dividir os fungos em três grupos, de acordo com o tipo de reprodução (MORAES et al., 2009) :

- Holomorfo: que se reproduz tanto sexuada quanto assexuadamente.

- Anamorfo: que se reproduz apenas assexuadamente.

- Teleomorfo: que se reproduz apenas sexuadamente.

\subsubsection{Fungos xilófagos}

Em condições aeróbias, os fungos xilófagos, baseado nas enzimas que produzem, podem apresentar três padrões ou tipos de degradação na madeira atacada: podridão branca, castanha ou branda (white, brown e soft rotem inglês) com base na classificação de cor e estrutura de resíduos de madeira depois da degradação (BLANCHETTE, 1998, ERIKSSON et al., 1990).

Os tipos de enzimas produzidos e o número de sequências de produção determinam a quantidade e a extensão de sua degradação (BLANCHETTE, 1991). Para os organismos xilófagos, a celulose constitui o nutriente mais nobre, pois sua hidrólise determina a produção de açucares que representam importantes fontes de energia para o microrganismo, quando digeridos. No caso de fungos ligninolíticos, como os que propiciam a podridão branca (ou fibrosa), a produção de enzimas que quebram a lignina representa um meio para a abertura de caminhos que levem a atingir as reservas de celulose presentes na madeira (KIRK et al., 1976). Os fungos de podridão fibrosa, embora estejam mais interessados na celulose, atacam praticamente todos os componentes da parede celular e a medida que é atacada adquire um aspecto esbranquiçado e fibroso (GONZÁLEZ, 2012 ). A maioria dos fungos de podridão branca é da divisão Basidiomycotina, portanto essa divisão tem muita importância para 
estudos de sobre degradação e deterioração de materiais de madeira (ERIKSSON et al., 1990).

Fungos de podridão castanha (ou cúbica) são geralmente degradantes de madeira de gimnospermas (as coníferas, como os pinheiros), muito usadas como madeiras industriais (ZABEL \& MORRELL, 1992). Eles degradam preferencialmente os componentes polissacarídeos da madeira (celulose e hemicelulose). As madeiras sob ataque de podridão castanha geralmente tem uma cor acastanhada (daí o nome da podridão) e uma aparência cúbica. A destruição das estruturas de fibras da madeira ocorre de tal forma que a madeira se contrai e racha o que resulta em sua aparência cúbica. Um dos fungos de podridão castanha mais destrutivos está o Serpulalacrymans. Essa espécie se espalha muito rapidamente pela madeira e é capaz, graças ao seu micélio diferenciado, de atravessar superfícies sem interesse nutritivo e invadir novos substratos. (BLANCHETTE, 2000, GONZÁLEZ, 2012).

Os fungos de podridão branda produzem buracos em espiral dentro da parede secundária das células de madeira seguindo a orientação de microfibrilas de celulose (DANIEL \& NILSSON, 1998). Em seções transversais de madeira pode-se observar buracos de diferentes tamanhos nas paredes laterais, enquanto que nas seções radiais ou tangenciais são observadas cavidades alongadas. Este tipo de decomposição ocorre principalmente quando a madeira fica exposta a umidade excessiva, mas também pode ocorrer em ambientes secos (BLANCHETTE, 2000).

Fungos da podridão branda são frequentemente encontrados em ambientes não favoráveis para o crescimento das espécies que produzem podridão branca e castanha, possuem enzimas que degradam a celulose e hemicelulose, ao passo que a lignina é ligeiramente modificada (BUCHER et al., 2004). Nos estágios avançados de decaimento, a madeira torna-se frágil e amarronzada.

\subsubsection{A biologia molecular na identificação de fungos}

$\mathrm{Na}$ área de estudos de biodeterioração por fungos, evidentemente, é muito desejável poder avançar na tarefa da obtenção do maior número possível de informações sobre o comportamento dos agentes responsáveis pela agressão aos materiais e sua resposta aos estímulos oriundos do meio em sua volta. Para tanto, o reconhecimento das 
efetivas espécies atuando nos diferentes substratos constitui um objetivo primordial, pois possibilita o acesso e aproveitamento de informações prévias disponíveis e a melhor circulação dos dados de pesquisa gerados na comunidade científica.

Tradicionalmente, essa meta tem sido perseguida por meio de métodos clássicos de identificação taxonômica baseada, essencialmente, na observação, ao microscópio ótico, das características morfológicas de organismos extraídos dos substratos atacados e crescidos in vitro. Tais características são comparadas a informações disponíveis na literatura por meio de chaves de interpretação taxonômica, um método que, certamente, requer muito treinamento e bastante experiência. Essa abordagem foi em parte adotada na parte experimental do presente trabalho, onde o suporte da co-orientadora do projeto se revelou determinante para o sucesso da empreitada.

Nos últimos anos, contudo, a identificação de fungos por meio de técnicas de biologia molecular, fundamentadas no sequenciamento do DNA, receberam atenção extraordinária haja vista as potencialidades que apresenta, a dizer: o fato de dispensar as etapas extremamente trabalhosas e que demandam habilidades muito aperfeiçoadas da identificação taxonômica; o fato de que permitem a diferenciação de espécies com uma sensibilidade e especificidade maior, já que, a identificação baseada na taxonomia clássica é utilizada apenas por marcadores morfológicos e análises bioquímicas, dificultando algumas vezes a correta classificação.

A identificação de fungos por técnicas de biologia molecular consiste, geralmente, na extração do DNA (tipicamente em quantidades mínimas) e na amplificação de regiões específicas através da reação em cadeia da polimerase (PCR, do inglês de Polymerase chain reaction). A PCR é uma das técnicas mais comuns utilizadas em laboratórios de pesquisas para diversas aplicações, como o sequenciamento de genes, diagnóstico de doenças hereditárias e identificação de "impressão digital" genética. Trata-se de um método de amplificação (de geração de múltiplas cópias) de DNA (ácido desoxirribonucleico) sem o uso de um organismo vivo. A amplificação de regiões específicas do DNA ocorre a partir de curtas sequências de pares de bases (oligonucleotídeos) denominados primers (ou iniciadores) em reações em cadeia mediadas por enzimas polimerases. Essas reações produzem uma multiplicação em escala exponencial do DNA, de modo que essas sequências possam ser analisadas, posteriormente, por técnicas de sequencimento ou outra abordagem. 
No caso de fungos especificamente, têm sido escolhidas pequenas sub-unidades dos genes que codificam o RNA ribossômico (rRNA), como as subunidades 18 e 28S . Tradicionalmente, as regiões ITS1, ITS2 e 5.8S são alvos escolhidos para a genotipagem de fungos, conforme representado na Figura 12.

As regiões ITS (do inglês de Internal Transcribed Spacer) do rRNA são regiões conservadas do DNA capazes de auxiliar no estabelecimento de relações filogenéticas e distinção de espécies (CHEN et al., 2004). A vantagem de se amplificar e sequenciar essas regiões para fins de identificação de fungos é que elas são comuns a todas as espécies, permanecem conservadas ao longo do processo evolutivo, mas, ainda assim, apresentam trechos de alta variabilidade genética que permitem discriminar gêneros e espécies.

A identificação de fungos endofíticos tem sido realizada por meio de regiões ITS que fornecem a possibilidade da identificação de gêneros de fungos isolados de diferentes fontes, pela amplificação, sequenciamento e comparação às sequências disponíveis em banco de dados (AZEVEDO et al., 2002), possibilitando sua utilização futura, inclusive, em processos biotecnológicos.

Considerando isso, adotou-se essa abordagem para complementação da caracterização dos fungos estudados, o que poderá permitir expandir o horizonte de oportunidades na identificação de agentes envolvidos na biodeterioração das madeiras no patrimônio histórico. 


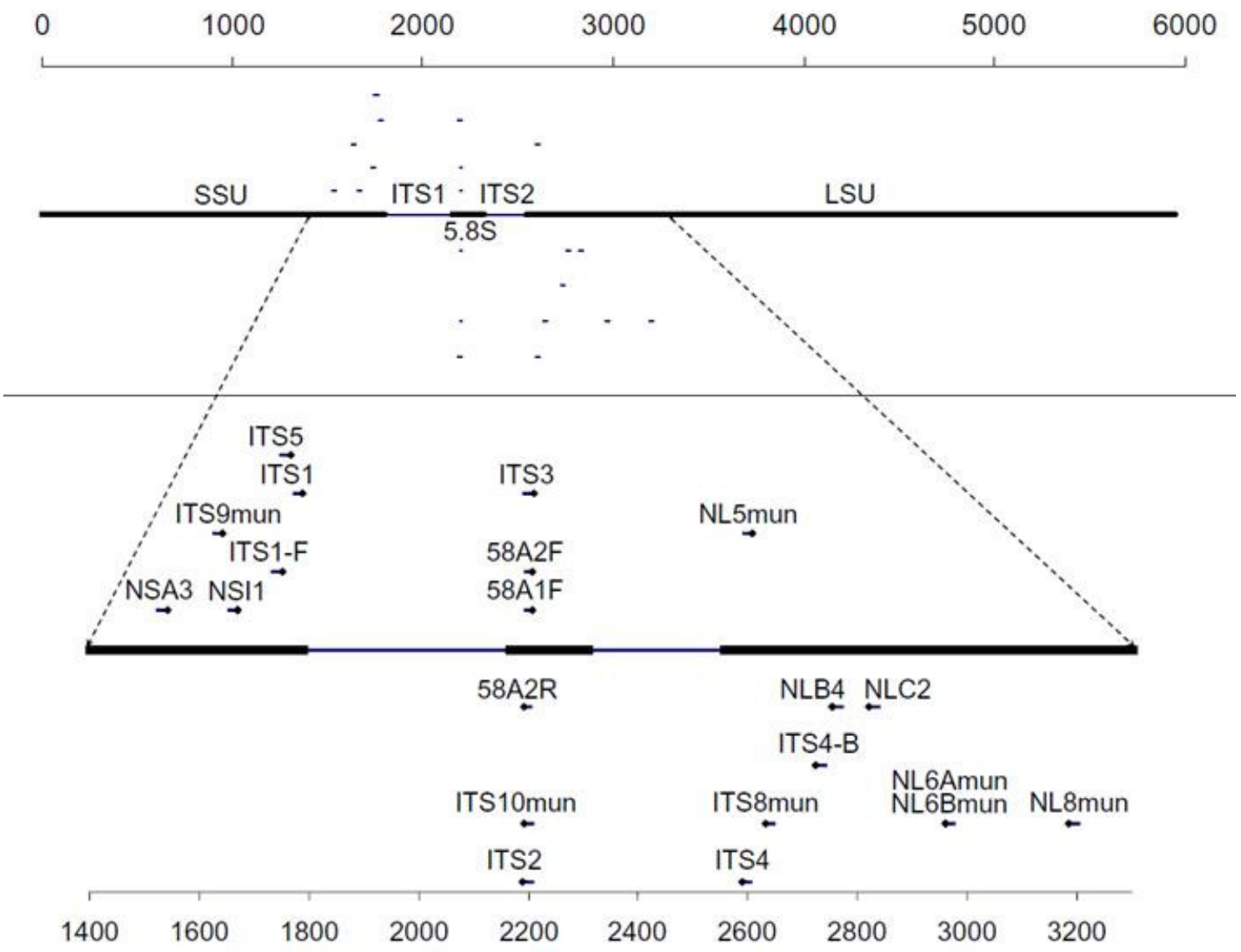

Figura 12. Diagrama que mostra a localização das regiões do rDNA objetivadas na identificação de fungos e a lista dos principais primers(ver definição no texto) desenvolvidos para essa finalidade. Fonte: MARTIN; RYGIEWICZ (2005). 


\section{JUSTIFICATIVA E OBJETIVOS}

A proteção do patrimônio cultural edificado no Vale Histórico Paulista justificase em primeiro lugar em função da manutenção da integridade física do legato de uma importante fase histórica do país que tem nas técnicas de construção, nas formas arquitetônicas e nos modelos de organização do espaço um testemunho tangível impar dos modos de pensar, sentir, fazer e viver de uma época por muitos aspectos esquecida. Testemunho concreto que permite ao homem de hoje compreender sua história, fortalecer sua identidade e refletir sobre os percursos de mudança trilhados pela sociedade, mas também viver experiências estéticas através da fruição da beleza artística - aqui admiravelmente emoldurada pela paisagem natural (embora alterada): todos processos essenciais na formação humana e no desenvolvimento pessoal e coletivo.

Acrescente-se a isso que, atualmente, o patrimônio histórico e artístico do Vale Histórico constitui-se também como fator potencial de desenvolvimento local da região ligado ao turismo cultural. Algumas iniciativas privadas e da sociedade civil organizada nesse sentido, a despeito do pouco apoio do poder público, começam a despertar o interesse das populações locais, cuja economia se encontra quase que inteiramente baseada numa pecuária leiteira de baixa rentabilidade e na exploração de recursos naturais já profundamente depauperados (p. ex., a cultura do eucalipto).

O patrimônio edificado do Vale encontra-se num estado de degradação crônica profunda resultante do desinteresse e descaso dos atores que deveriam estar envolvidos na sua proteção, da depredação e do vandalismo. Esse fato determina uma exacerbação de sua vulnerabilidade à ação do tempo (cronológico e, portanto, ação natural de decaimento) e fatores meteorológicos (chuvas, granizo, ventos fortes, raios,), bem como às consequências desses últimos (inundações, erosão do solo, desabamentos), por sua vez acentuada pelas mencionadas alterações do uso do solo e pelas tendências de alteração dos padrões climáticos observadas nos últimos anos.

A esse respeito, a UNESCO já se fez porta-voz das preocupações com os riscos de degradação aos quais o patrimônio cultural mundial pode estar exposto em um contexto de mudanças climáticas e apelou em vários momentos pelo respeito dos compromissos de incentivo a pesquisa na área de preservação do patrimônio (UNESCO, 1972; UNESCO, 2006). Enquadra-se nesse cenário, a agressão biológica e 
microbiológica sobre os materiais edificados e as decorações, a qual representa um risco iminente adicional muito grande e precisa de uma atenção específica, tanto com a sistematização dos conhecimentos e levantamento dos avanços científicos e tecnológicos mais recentes, como pelo entendimento das especificidades de cada local (em termos da caracterização dos materiais em si e da qualificação e quantificação dos agentes agressores). Cabe destacar que a conservação de bens culturais exige a elaboração de estratégias eficientes e focadas visando otimizar o processo de proteção. Nesse âmbito tem importância determinante o emprego de uma abordagem experimental que forneça uma sólida base de conhecimento para nortear o diagnóstico do risco e o encaminhamento de soluções..

À luz de quanto exposto acima, o objetivo geral deste projeto foi contribuir para a elaboração de estratégias de conservação dos bens culturais edificados no Vale Histórico de São Paulo com enfoque em processos de biodeterioração da madeira e atenção para abordagens preventivas.

Para tanto, pretendeu-se avaliar a presença de fungos endófitos de madeira nas estruturas das edificações históricas da região em exame e seus impactos negativos decorrentes de sua ação metabólica específica nas condições climáticas locais e suas perspectivas de exacerbação associada às mudanças climáticas futuras. Sendo assim, os objetivos específicos deste projeto foram os seguintes:

i) Sistematizar conhecimentos teóricos sobre a degradação biológica da madeira e, em particular, sobre os fatores determinantes no desenvolvimento de fungos;

ii) Sistematizar dados e informações sobre as condições climáticas (T e UR) da região do Vale Histórico de São Paulo e cenários futuros de mudanças nos padrões climáticos;

iii) Avaliar a presença de fungos xilófagos nas madeiras das edificações históricas, com destaque para os elementos arquitetônicos estruturais, e as formas de ação desses fungos na biodeterioração;

iv) Estudar a cinética de crescimento dos fungos de maior potencial de impacto nas condições climáticas médias atuais e sua resposta a alterações nos padrões climáticos mais prováveis para a região. 


\section{MATERAIS E MÉTODOS}

\subsection{Coleta de amostras de madeira}

Foram coletadas amostras de madeiras estruturais cujos aspectos gerais apresentem sinais visíveis de deterioração por fungos. Todas as coletas foram realizadas em pontos internos de edificações urbanas ou rurais distribuídas nos municípios de São José do barreiro, Areias e Bananal.

As coletas consistem na extração de pequenos pedaços de madeira das estruturas de interesse. Essas extrações foram realizadas com estiletes, facas e outros materiais cortante, que foram usados para fazer cortes das amostras, e papel para armazena-las. As amostras foram acondicionadas em envelopes de papel para evitar a contaminação e acúmulo de umidade e levadas ao laboratório para isolamento dos fungos. Foram coletadas 39 amostras de maneira nos três municípios acima citados.

\subsection{Isolamento, cultivo e conservação dos fungos das amostras de madeira}

O isolamento, cultivo e armazenamento das cepas foram realizados da seguinte forma.

Primeiramente, são preparados meios de batata dextrose ágar (PDA, preparado misturando-se $39 \mathrm{~g}$ de PDA comercial, marca Fluka ou Acumédia, $10 \mathrm{~g}$ de ágar, Acumédia, e 1 L de água) e meios de ágar-água (18g/L de ágar). Em todo o trabalho, a água utilizada foi deionizada. Os meios de PDA têm o crescimento dos microrganismos facilitado, pela maior disponibilidade de nutrientes. Já os meios de ágar-água têm a vantagem de evitar o crescimento de microrganismos oportunistas. Portanto, foram feitos isolamentos das duas formas.

Com pinças esterilizadas, os pedaços de madeira foram mergulhados rapidamente em uma solução de água e etanol 30:70, para evitar o desenvolvimento de fungos oportunistas na parte externa da amostra, e depois colocados em papel filtro (também esterilizados) para secagem;

Os pedaços de madeira, depois de secos, foram colocados nas placas de PDA e ágar-água. Armazenou-se as placas a temperatura ambiente para crescimento das hifas. 
Os fungos que começaram a se desenvolver nas placas com amostras de madeira foram repicados em novas placas de PDA para obtenção do fungo puro. Depois que as colônias foram repicadas, as placas foram armazenadas em uma estufa a $30^{\circ} \mathrm{C}$ para crescimento das cepas puras que seriam utilizadas no projeto.

A conservação das cepas isoladas foi feita de duas formas. O primeiro método envolveu resfriamento a menos $-80{ }^{\circ} \mathrm{C}$. Para tanto, as cepas foram repicadas em placas com pequenos pedaços de papel filtro autoclavados. Quando as colônias cresceram, os papeis filtros impregnados com as hifas dos fungos foram retirados das placas e armazenados em um congelador de $-80{ }^{\circ} \mathrm{C}$ de temperatura. Nessas condições as cepas podem ficar armazenadas em longo prazo.

A outra forma de armazenamento consistiu na técnica do bico de flauta. Nessa técnica o meio de cultura (PDA) é autoclavado em tubos de ensaio. Assim que saem da autoclave os tubos de ensaio são inclinados para que o meio endureça formando uma espécie de bico (bico de flauta).

Esse tipo armazenamento (Figura 13) propicia menor consumo do meio pelo fungo e a manutenção da cepa em temperatura pouco maior que $4^{\circ} \mathrm{C}$ por alguns meses.

Os fungos também continuaram sendo cultivados em placas de petri com meio de cultivo, mas como material a ser utilizado nos ensaios e observações e não propriamente para conservação da cepa. 


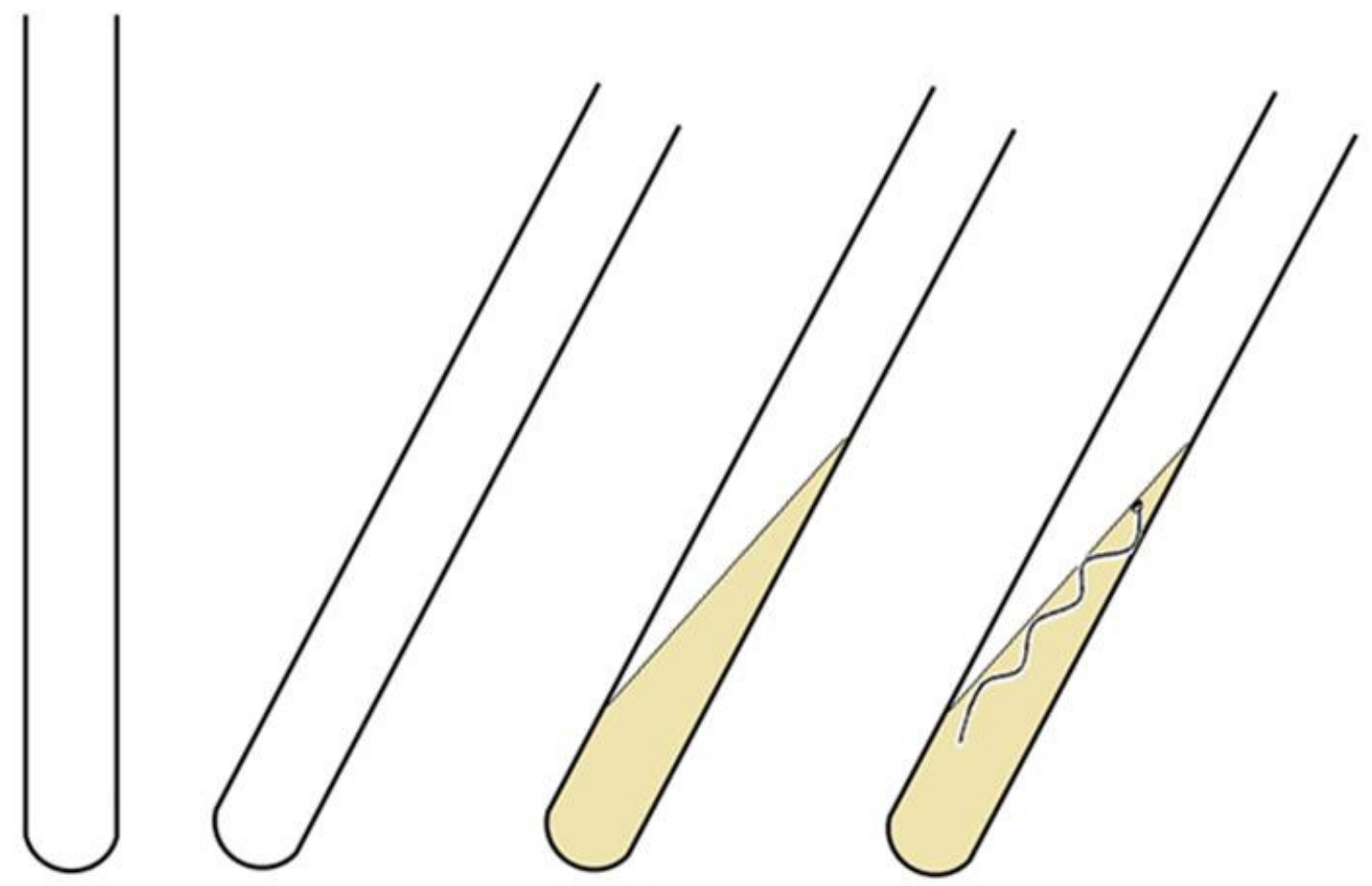

Figura 13. Esquema mostrando o processo de manutenção dos fungos pela técnica de cultivo em "bico de flauta".

\subsection{Avaliação da atividade enzimática dos fungos isolados}

\subsubsection{Ensaios para atividade celulolítica}

A atividade celulolítica de trita e quatro cepas isoladas foi avaliada por meio de testes com o corante vermelho de congo. Para isto, discos de micélio de aprox. $8 \mathrm{~mm}$ de diâmetro de colônias de fungos de cerca de uma semana de idade foram cortados e inoculados no centro de placas de petri com meio de Luria Brentani (LB) preparado com $1 \%$ de carboximetilcelulose (CMC, Sigma, 10g/L; NaCl, Qhemis, 10g/L; triptona, Acumédia, 10g/L; extrato de levedura, Fluka, 7,5 g/L; ágar, 20g/L) previamente autoclavado. As placas foram armazenadas em uma estufa a $30^{\circ} \mathrm{C}$ para crescimento das colônias. Após esse período, as colônias foram retiradas da estufa e seu diâmetro foi medido com o uso de uma régua.

Para as observações de atividade celulolítica, foi aplicada uma solução de vermelho de congo $0,1 \%$ (Vetec, em solvente de aquoso a $1 \%$ de etanol) nas placas com os fungos. Após 1 hora, a solução de vermelho de congo é retirada das placas e nelas se 
verte uma solução $1 \mathrm{M}$ de $\mathrm{NaCl}$, para descoloração. A solução de $\mathrm{NaCl}$ deve ser aplicada duas vezes, com intervalos de meia hora.

O corante vermelho de congo deve reagir com a $\mathrm{CMC}$, promovendo uma coloração avermelhada no meio. Por outro lado, a atividade celulolítica dos fungos quebra o CMC em monómeros de glicose os quais não reagem com o corante. Assim, após as aplicações da solução de $\mathrm{NaCl}$, deve surgir um halo que não apresenta a coloração avermelhada onde ocorreu a quebra do CMC. Esse halo, que indica a atividade celulolítica, é medido com um paquímetro (TEATHER \& WOOD, 1982).

A atividade dos fungos no meio de ágar-CMC ainda foi medida com o Índice de Atividade Enzimática Relativa (ICMC) que é igual à razão entre o diâmetro do halo e o diâmetro das colônias (TEATHER \& WOOD, 1982;).

\subsubsection{Ensaios de atividade ligninolitica}

Foram realizados três tipos de ensaios para avaliação da capacidade dos fungos de degradar lignina (atividade ligninolítica): ensaios de lignina peroxidase (LiP), ensaios de manganês peroxidase (MnP) e ensaios de tanase. A degradação de lignina é decorrente de um conjunto de enzimas extracelulares que incluem lacases, lignina peroxidases e Mn peroxidases, que atuam em conjunto com oxidases produtoras de peróxido de hidrogênio (Levin et al., 2012). Os mesmos mecanismos são responsáveis por degradar uma vasta gama de moléculas, inclusive alguns corantes, entre eles o Azure B, que apresenta uma estrutura aromática policíclica.

Para o ensaio de lignina peroxidase, vinte e duas cepas foram inoculadas em placas contendo extrato de malta agarizado (extrato de malta, Acumédia, 12,7 g/L; glucose, Vetec, 10 g/L; ágar, 20 g/L) suplementado com Azure B (Sigma). Para cada placa de petri de $90 \mathrm{~mm}$ de diâmetro, foram adicionados $20 \mathrm{ml}$ de meio. O princípio é que fungos capazes de degradar a lignina devem poder atacar a estrutura da molécula de Azure B e proporcionar sua (parcial) degradação. Uma placa controle sem corante também foi inoculada com cada cepa. As placas foram incubadas a $30^{\circ} \mathrm{C}$ durante $07-28$ dias. A atividade de enzimas LiP é indicada pelo surgimento de uma zona descolorida que aparece quando o fungo degrada o corante.

Para os ensaios de manganês peroxidase e com ácido tânico, procedeu-se da 
mesma forma que o ensaio de lignina peroxidase, mas no primeiro caso as cepas foram inoculadas em meio de malta claro (glucose $10 \mathrm{~g} / \mathrm{L}$; extrato de malta 6,5 g/L; agar 20 $\mathrm{g} / \mathrm{L}$; e $\mathrm{MnCl}_{2}$, Sigma, $1 \mathrm{mM}$ ) e no segundo, em vez da adição de Azure B, foi adicionado ácido tânico (Vetec, 0,5 \%). Os fungos que capacidade de degradação de lignina devem deixar o meio com um halo alaranjado (teste de MnP) decorrente da formação e precipitação de Mn(III) ou amarronzado (teste de ácido tânico).

\subsection{Identificação molecular}

\subsubsection{Extração de DNA}

As cepas a serem identificadas foram inoculadas em meio de PDA coberto com uma membrana semipermeável (celofane biodegradável). A cepa não foi inoculada, diretamente, no meio de cultura para que não contaminasse a amostra no momento da extração. A membrana semipermeável permite a nutrição do fungo sem contato direto com o substrato. As colônias cresceram até tomar toda a superfície do celofane e foram armazenadas a $4^{\circ} \mathrm{C}$. Para a extração, os micélios crescidos sobre as membranas semipermeáveis foram raspados e colocados em almofarizes, nos quais se adicionou nitrogênio líquido. Após a maceração do material, o pó resultante em cada almofariz foi armazenado em microtubo de 1,5 $\mathrm{ml}$ e rotulado com o nome da cepa correspondente.

O pó macerado com nitrogênio foi, então, ressuspenso em $500 \mu 1$ de solução de sorbitol 1M (Sigma), EDTA $10 \mathrm{mM}$ (Sigma), $\beta$-mercaptoetanol $14 \mathrm{mM}$ (Merck)) ao qual se adicionaram $6 \mu 1$ da enzima Liticase $4500 \mathrm{U} / \mathrm{mL}$ (Invitrogen).

Os microtubos contendo a mistura foram incubados por uma hora a $37^{\circ} \mathrm{C}$ para geração de esferoplastos.

Depois da incubação, os microtubos foram centrifugados a 3000 x g por $10 \mathrm{~min}$ à temperatura ambiente para sedimentação dos esferoplastos. Ao fim da centrifugação, descartou-se o sobrenadante.

Seguiu-se com a ressuspensão dos esferoplastos em $180 \mu$ l de tampão "Pure Link ${ }^{\mathrm{TM}}$ Genomic Digestion", conforme instruções do fabricante (Thermo Fischer Scientific). Adicionaram-se, a seguir, $20 \mu \mathrm{l}$ de proteinase $\mathrm{K} 20 \mathrm{mg} / \mathrm{mL}$ (Invitrogen), sendo a solução misturada utilizando-se vórtex. Os microtubos foram, então, incubados 
a $55^{\circ} \mathrm{C}$ por $45 \mathrm{~min}$. Posteriormente, adicionaram-se $20 \mu \mathrm{l}$ de RNaseA $20 \mathrm{mg} / \mathrm{mL}$, misturando-se bem com a utilização do vórtex. Foi realizada a incubação da mistura, à temperatura ambiente por $2 \mathrm{~min}$ e, após esse período, o material foi centrifugado a 12000 x g. O sobrenadante foi transferido para um microtubo estéril. Ao microtubo, adicionaram-se $200 \mu \mathrm{l}$ de "Pure Link GenomicLisis/Binding Buffer" (Thermo Fischer Scientific) misturando-se bem no vórtex até a obtenção de uma solução homogênea. Finalmente, adicionaram-se $200 \mu \mathrm{l}$ de etanol 100\% misturando-se bem por 15 segundos usando-se vórtex.

A etapa seguinte foi a de binding (ligação) que consiste na ligação do DNA extraído na coluna de purificação. Os $640 \mu 1$ de material obtido na etapa anterior foram transferidos para uma coluna (PureLink ${ }^{\circ}$ Spin Column), a qual foi inserida dentro de um tubo estéril. As colunas foram centrifugadas a 10000 x g por 1 min. O conteúdo do tubo foi, então, descartado e a coluna transferida para outro tubo estéril.

Seguiu-se com a etapa washing (lavagem), cuja finalidade é a de eluir o material que não está ligado à coluna. Para tanto, foram adicionados $500 \mu 1$ de tampão "Wash 1" O conteúdo foi centrifugado a 10000 x g por $1 \mathrm{~min}$, e o material eluído foi descartado. Adicionaram-se $500 \mu 1$ de tampão "Wash 2" na coluna. A coluna foi centrifugada por 3 $\min$ a $10000 \mathrm{x}$ g.

Finalmente, deu-se início à etapa de eluição. Para a eluição do DNA, a coluna foi colocada em um tubo estéril, sendo adicionados $50 \mu 1$ de "Genomic Elution Buffer". A coluna foi incubada à temperatura ambiente por $1 \mathrm{~min}$ e, então, centrifugadas em 12000 x g à temperatura ambiente.

\subsubsection{Amplificação}

Para a amplificação dos marcadores genéticos utilizados para fungos, primers foram especificamente desenhados (ver Tabela 4). O DNA $(2,5 \mu \mathrm{L})$ foi misturado com 1 $\mu \mathrm{L}$ de tampão para PCR 10 vezes concentrado (Invitrogen), $0,4 \mu \mathrm{L}$ da mistura de dNTPs $10 \mathrm{mM}$ (Invitrogen), 0,1 $\mu \mathrm{L}$ de cada um dos primers $40 \mu \mathrm{M}$ (forward e reverse), $0,05 \mu \mathrm{L}$ de Taq polimerase (Invitrogen, $5 \mathrm{U} / \mathrm{mL}$ ), num volume final de $10 \mu \mathrm{L}$. O DNA foi amplificado em quarenta ciclos térmicos a $94^{\circ} \mathrm{C}$ por 30 segundos, $54^{\circ} \mathrm{C}$ por 30 
segundos e $72^{\circ} \mathrm{C}$ por 1 minuto (PTC- $100^{\mathrm{TM}}$, Programmable Thermal Controller, MJ Research Inc., EUA).

Tabela 4. Sequências dos primers usados no trabalho

\begin{tabular}{ll}
\hline Gene & Sequência \\
\hline ITS1 & TCCGTAGGTGAACCTGCGG \\
ITS4 & TCCTCCGCTTATTGATATGC \\
NS3 & GCAAGTCTGGTGCCAGCAGCC \\
NS4 & GTGCCCTTCCGTCAATT \\
\hline
\end{tabular}

\section{ANÁLISE DA AMPLIFICAÇÃO DOS FRAGMENTOS}

Os fragmentos de DNA amplificados por PCR foram analisados em gel de agarose 1,0\% preparado em Tris $40 \mathrm{mM}$, acetato $20 \mathrm{mM}$, EDTA $1 \mathrm{mM}$ (TAE) 1x pH 8,0. Antes da polimerização do gel, foram adicionados $3 \mu \mathrm{L}$ de uma solução de SYBR Green ${ }^{\circledR} 10.000$ x concentrado, segundo instruções do fabricante (Invitrogen).. As amostras $(10 \mu \mathrm{L})$ foram submetidas à corrida eletroforética em TAE a $100 \mathrm{~V}$ por, aproximadamente, 1 hora à temperatura ambiente. Para comparação da massa dos fragmentos obtidos, foram utilizados $3 \mu \mathrm{g}$ do padrão de massas moleculares “100pbLadder" (Invitrogen) . As bandas de DNA foram visualizadas em transiluminador. A imagem foi fotografada para registro e avaliação da pureza do material.

\subsubsection{Purificação do DNA para sequenciamento}

O protocolo de purificação foi realizado usando-se um kit (Thermo Fischer Scientific) conforme as instruções do fabricante.

Brevemente, foram adicionados 4 volumes de PureLink® Binding Buffer (B2) contendo isopropanol para cada volume de produto de PCR, que no caso foi de $40 \mu \mathrm{L}$, aproximadamente. . As amostras foram, então, adicionadas às colunas de purificação (Purelink $^{\circledR}$ Spin Collumns) e centrifugadas a 10000 x g, à temperatura ambiente, por 1 minuto. O material não retido foi descartado e a coluna transferida para outro tubo. 


\subsubsection{Lavagem}

A coluna foi, então, lavada com $650 \mu$ le Wash Buffer contendo etanol . Centrifugaram-se as colunas a $10000 \mathrm{x}$ g ), à temperatura ambiente por 1 minuto. Descartou-se o fluido do tubo coletor e a coluna foi colocada em outro tubo. As colunas foram, então, centrifugadas à $12000 \mathrm{x}$ g, à temperatura ambiente por dois minutos e meio para remoção de qualquer resíduo do Wash Buffer. O tubo de coleta foi descartado.

\subsubsection{Eluição do DNA}

Para eluição do DNA, a coluna foi colocada em um limpo de 1,7 ml. Adicionaram-se $50 \mu \mathrm{l}$ de Elution Buffer no centro da coluna. A coluna foi, então, incubada à temperatura ambiente por 1 minuto e, posteriormente, centrifugada a 12000 $\mathrm{x}$ g por 2 minutos. Os produtos de PCR purificados foram estocados a $-20^{\circ} \mathrm{C}$.

\subsubsection{Sequenciamento}

\subsubsection{1. $\quad P C R$}

Os componentes do PCR de sequenciamento foram: $8 \mu 1$ de DNA purificado e 12,3 $\mu \mathrm{l}$ do "mix" composto por $8 \mu \mathrm{l}$ de Big DyeTerminator V:3 Cycle, $4 \mu 1$ de Big DyeTerminator V1.1 V3.1 5x Sequency Buffer, conforme instruções do fabricante, 0,3 $\mu 1$ do Primer ITS4. Para sequenciamento, foram utilizados apenas os produtos de PCR obtidos na amplificação comprimer ITS.O programa do PCR foi: $94^{\circ} \mathrm{C}$ por $2 \mathrm{~min}$, trinta ciclos térmicos de $94^{\circ} \mathrm{C}$ por $30 \mathrm{~s}, 54^{\circ} \mathrm{C}$ por $30 \mathrm{~s} \mathrm{e} 72^{\circ} \mathrm{C}$ por $1 \mathrm{~min}$, e elongação final a $72^{\circ} \mathrm{C}$ por $2 \mathrm{~min}$. 


\subsubsection{Precipitação do DNA}

Para precipitação do material para a etapa de seqüenciamento, adicionaram-se, aos produtos de PCR, $25 \mu \mathrm{l}$ de uma solução de etanol 100\% (28,6 $\mu \mathrm{l})$ e NaOAc 2,5M $(1,15 \mu 1)) \mathrm{pH} 5,2$. A mistura foi agitada em vórtex. As amostras foram incubadas em banho de gelo por 15 minutos. As mesmas foram centrifugadaspor 20 minutos a 12000 x g. Descartou-se o sobrenadante, sendo, em seguida, adicionados $50 \mu \mathrm{l}$ de etanol. As misturas foram centrifugadasa 12000 x g por 20 minutos .. Descartou-se o sobrenadante e as amostras foram secas no escuro.

\subsubsection{Sequenciamento capilar}

O sequenciamento do DNA foi realizado no Instituto de Química da Universidade de São Paulo, por eletroforese capilar, segundo a técnica de Sanger.

\subsubsection{Análise das sequências}

Foi utilizado o programa BioEdit para análise da qualidade das sequências obtidas. Inicialmente, foram selecionados os trechos das sequências que permitiram correta identificação da base correspondente.

A partir dos trechos selecionados, as sequências foram comparadas a outras depositadas em banco de dados, utilizando-se a ferramenta "Standard Nucleotide BLAST" em <https://blast.ncbi.nlm.nih.gov/Blast.cgi?PAGE_TYPE=BlastSearch> para encontrar as prováveis espécies das cepas estudadas.

\subsection{Coleta de dados para simulação de microclima}

Um dos objetivos desse projeto foi sistematizar conhecimentos sobre as mudanças climáticas futuras na região investigada, avaliar as efetivas alterações nas condições microclimáticas dos ambientes indoor onde se encontram as estruturas de 
madeira que se busca conservar e as respostas a tais alterações dos agentes de biodeterioração. Nesse sentido, a partir das previsões de mudanças no clima determinou-se a possível alteração microclimática nas estruturas de interesse para a pesquisa. Nesse sentido, primeiramente tem-se as previsões globais de mudanças no clima que indicam de forma bem consolidada aumentos futuros na temperatura média global e aumentos na temperatura média em território brasileiro. Entretanto para o presente estudo é necessária previsões com resolução regionais para ter-se uma previsão adequada para o recorte geográfico de interesse do trabalho. Para tanto, contamos com a colaboração da Profa. Rita Y. Ynoue do IAG-USP que forneceu dados de simulações de clima atual (ERA-Interim e HadCM3-atual) e de clima futuro (HadCM3-futuro) para a região do Vale do Paraíba Paulista.

Para entender o comportamento dos microclimas indoor em função da forçante radiativa associada ao ambiente exterior foram coletados dados de temperatura e umidade relativa em locais distintos das casas sedes de quatro fazendas históricas da região. Essas fazendas são:

- a Fazenda São Francisco (localização 22³7'48.00"S, 44³6'5.00"O, altitude 500 m, Figura 14), onde foram realizadas medições de 1/1/15 a 31/12/15 no sótão, em duas salas do piso principal de vivência da casa e em duas salas no piso inferior onde hoje são abrigados locais de visitação (uma lojinha e um pequeno museu, esse supostamente climatizado);

- a Fazenda São Miguel (localização 2240'52.06"S, 44³5'59.03"O, altitude 700 m, Figura 15), onde foram realizadas medições de 1/1/15 a 31/12/15 no sótão, em três salas do piso principal de vivência da casa e em uma sala no piso inferior que hoje funciona como local de guarda de ferramentas e objetos históricos. A relação dos locais de instalação de cada aparelho de medição foi perdida num acidente informático e foi reconstruída tentativamente pela análise dos resultados obtidos;

- a Fazenda Catadupa (localização: 22³9'54.54"S, 44³1'54.10"O, altitude 600 m, Figura 16) onde foram realizadas medições de 1/6/13 a 31/5/14 no sótão, em uma sala do piso principal de vivência da casa e na senzala doméstica que corresponde a um porão no piso inferior, hoje funcionando como local de guarda de ferramentas. No caso dessa fazenda, constatou-se que a instalação 
efetiva dos aparelhos nos devidos locais foi efetuada, pelos proprietários, em data posterior a $1 / 6$, como pôde ser aferido pela absoluta igualdade de dados até aproximadamente meados de setembro 2013;

- e a Fazenda Vargem Grande (localização 2241'37.67"S, 4440'39.54"O, altitude 650 m, Figura 17) onde foram realizadas medições de 1/6/13 a 31/5/14 no sótão, em uma sala do piso principal de vivência da casa e numa sala, também de vivência, no piso inferior.. No caso dessa fazenda, os dados referentes ao piso inferior do período 1/11/13 a 4/2/14 foram perdidos devido a um acidente na programação do aparelho.

Em parte do tratamento dos dados, foi necessário utilizar a pressão atmosférica: essa foi obtida da estação automática mais próxima do Instituto Nacional de Meteorologia (InMet, estação de Resende, A609, localização 22²7'3,33"S, $44^{\circ} 26^{\prime} 40,01^{\prime \prime} \mathrm{O}, 439 \mathrm{~m}$, instalada a $25 \mathrm{~km}$ da fazenda mais próxima e $36 \mathrm{~km}$ da mais distante) descarregados a partir da plataforma Banco de Dados Meteorológicos para Ensino e Pesquisa (BDMEP, www.inmet.gov.br/portal/index.php?r=bdmep/bdmep). 

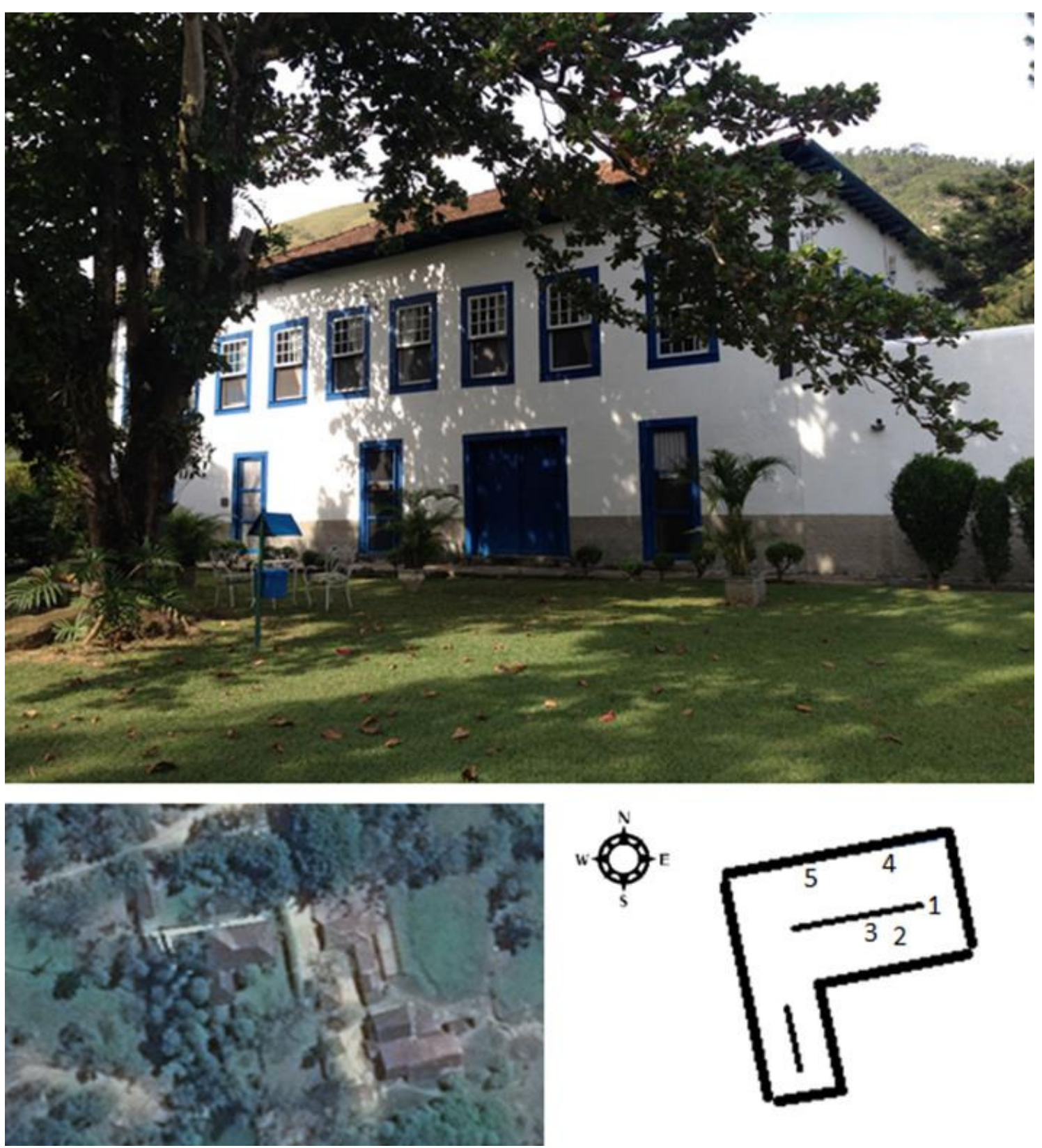

Figura 14. Fazenda São Francisco na visão frontal (lado NW) e em imagem do google Earth correspondente a altura de $200 \mathrm{~m}$ acima da fazenda. Na planta, estão indicados os pontos de instalação dos dataloggers para as medidas microclimáticas: Sótão (1), quarto de dormir no nível principal da casa correspondente às janelas superiores da fachada (2), corredor no nível principal da casa correspondente às janelas superiores da fachada (3), salas no piso inferior (lojinha e museu) correspondentes aos vãos inferiores da fachada (4 e 5). Fonte: acervo pessoal do orientador. 

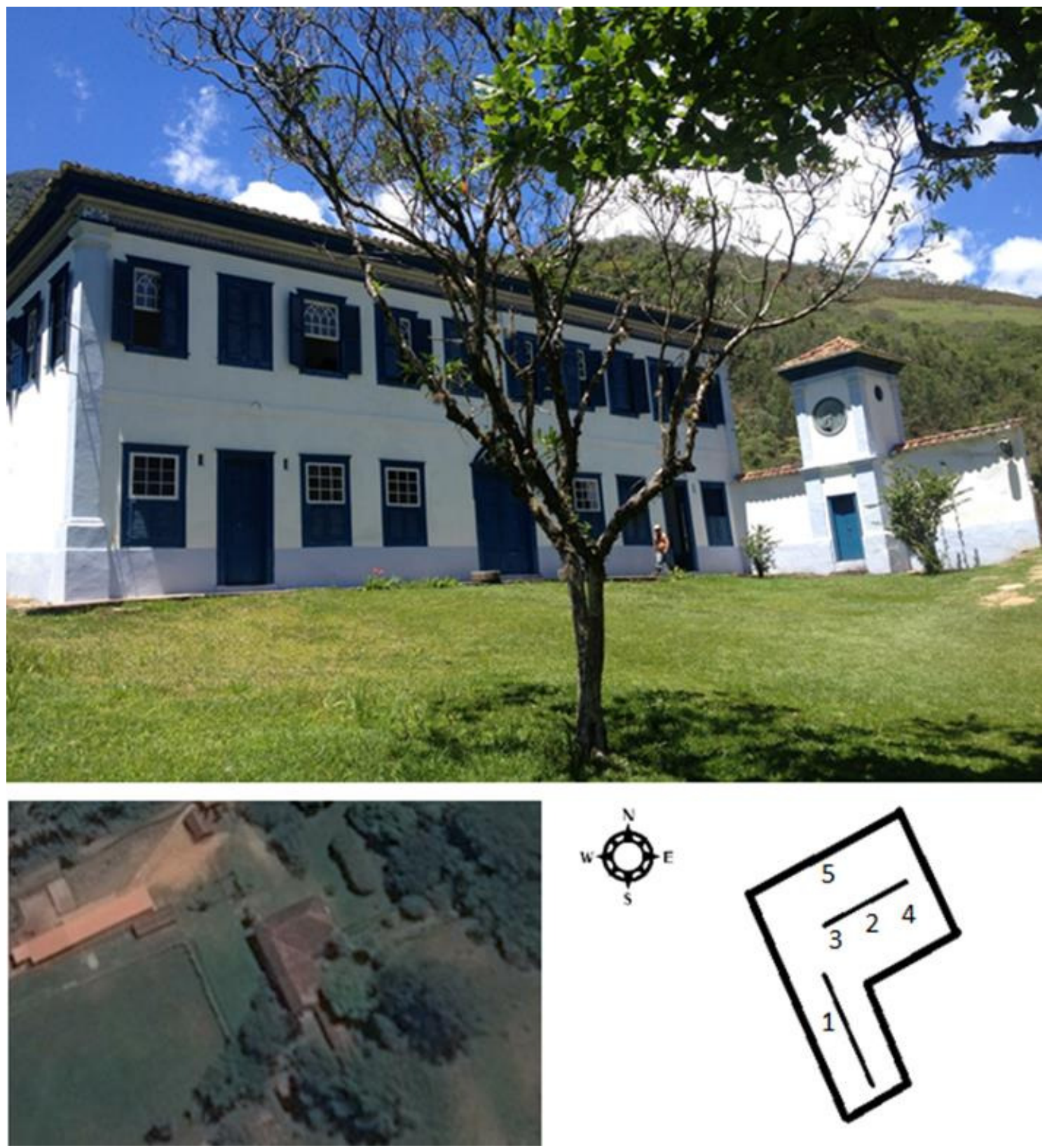

Figura 15. Fazenda São Miguel na visão frontal (lado NW) e em imagem do google Earth correspondente a altura de $200 \mathrm{~m}$ acima da fazenda. Na planta, estão indicados os pontos de instalação dos dataloggers para as medidas microclimáticas: Sótão (1), salas no nível principal da casa correspondente às janelas superiores da fachada (2-4), sala no piso inferior correspondentes a vão inferior na fachada (5). Fonte: acervo pessoal do orientador. 

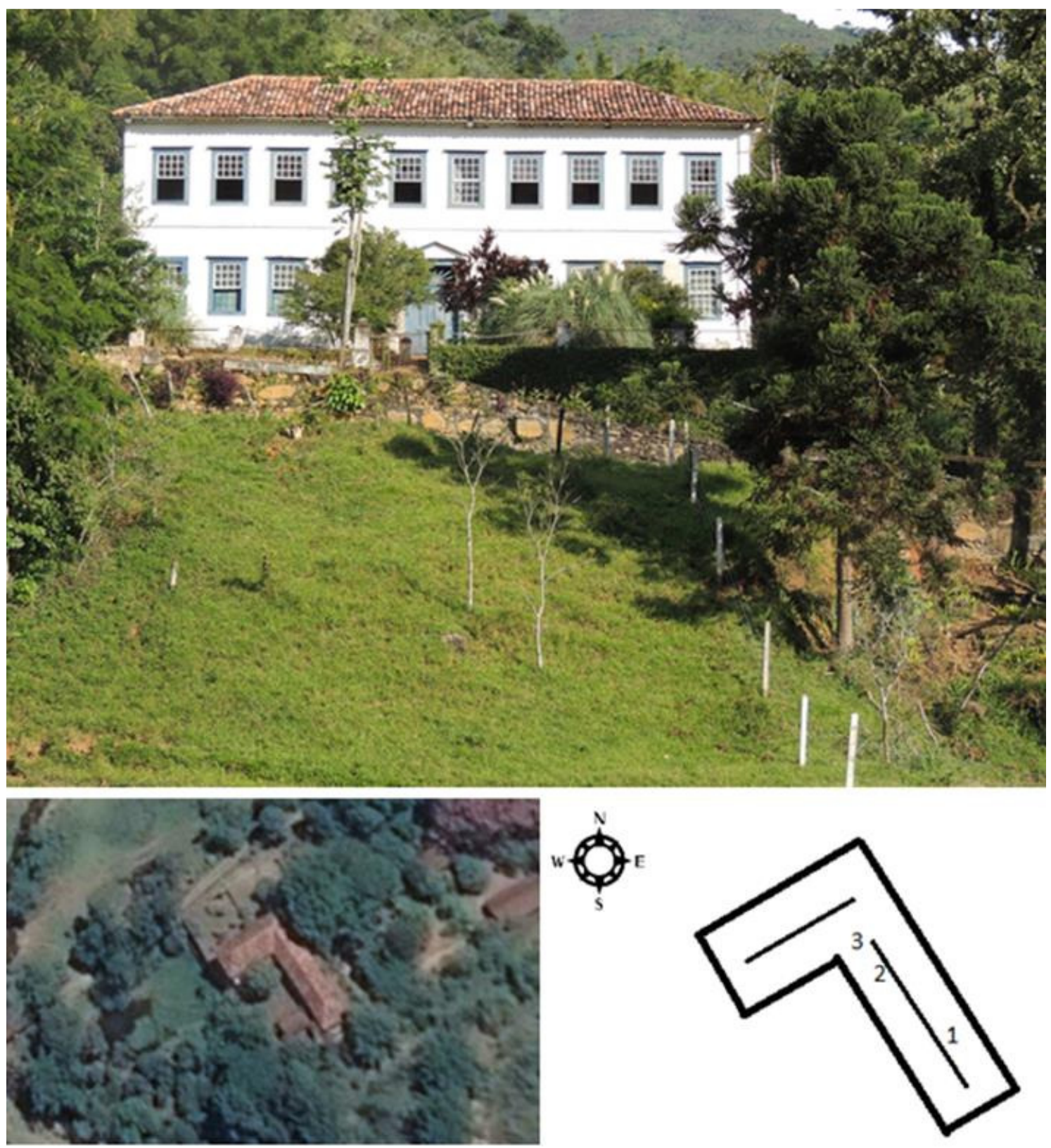

Figura 16. Fazenda Catadupa na visão frontal (lado NW) e em imagem do google Earth correspondente a altura de $200 \mathrm{~m}$ acima da fazenda. Na planta, estão indicados os pontos de instalação dos dataloggers para as medidas microclimáticas: Sótão (1), sala no nível principal da casa correspondente às janelas superiores da fachada (2) e senzala doméstica correspondente a nível intermediária entre as duas fileiras de janelas da fachada (3). Fonte: acervo pessoal do orientador. 

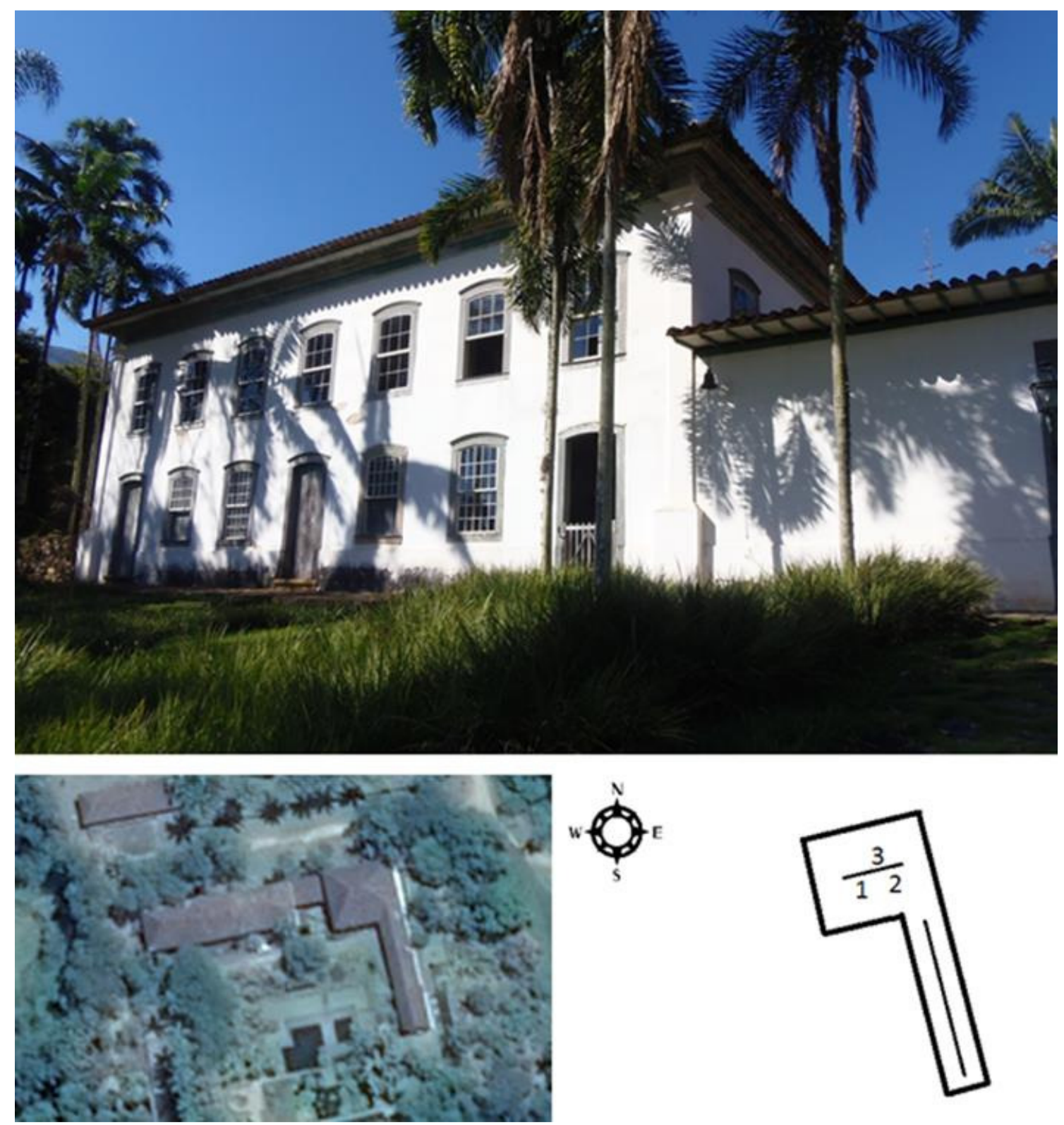

Figura 17. Fazenda Vargem Grande na visão frontal (lado NW) e em imagem do google Earth correspondente a altura de $200 \mathrm{~m}$ acima da fazenda. Na planta, estão indicados os pontos de instalação dos dataloggers para as medidas microclimáticas: Sótão (1), sala no nível principal da casa correspondente às janelas superiores da fachada (2) e sala no nível inferior correspondente fileira inferior de janelas da fachada (3). Fonte: acervo pessoal do orientador.

Para as medidas, sempre se procurou manter os sensores a uma altura de aprox. 2,5-3,0 m, apoiados ou colados numa superfície de vidro ou de madeira, sem a incidência de fontes de calor e longe de eventuais fontes de umidade. Os dados foram obtidos com dataloggers HOBO Onset, modelo U10-003, dispositivos cuja calibração é certificada pelo fabricante por um período de um ano e que apresentam precisão nominal de $0,2{ }^{\circ} \mathrm{C}$ na temperatura e $2,5 \%$ na UR. Tais sistemas foram programados para 
registrar T e UR uma ver por hora no minuto 00 e para calcular e armazenar os valores máximos, mínimos e médios diários das duas grandezas (em determinados casos, essa operação foi feita a posteriori no programa Excel). Os aparelhos são programados e lidos por meio do software Hoboware da empresa que desenvolve os dataloggers.

Além disso, os mesmos dados foram coletados numa estação externa instalada numa área aberta na frente da Fazenda Catadupa a uma altura de aprox. 2,5 m. Essa estação consiste também de um datalogger (HOBO Onset, modelo U23-002, com calibração certificada, precisão nominal de $0,2{ }^{\circ} \mathrm{C}$ na temperatura e $2,5 \%$ na UR) que é montado num abrigo para proteção contra as intempéries e a radiação solar e é dotado de uma sonda para a comunicação externa que se dá por sinais óticos. Infelizmente, os dados do período de 18/3/15 a 1/6/15 foram perdidos por causa do esgotamento da bateria do datalogger

\subsection{Análise da resposta microbiológica a diferentes temperaturas}

Para verificação do impacto das variações da temperatura no crescimento dos fungos foram escolhidas cepas que (i) obtiveram resultado positivo nos testes de atividade celulolítica, (ii) obtiveram resultado positivo em pelo menos dois dos três testes de atividade ligninolítica ou obtiveram resultado positivo em um teste de atividade ligninolítica e foram identificados, a princípio, como pertencente ao filo Basidiomycota, pois se trata do filo com os principais agente da podridão branca. Sendo assim, foram escolhidas as cepas com potencial lignocelulolítico mais evidente.

Os parâmetros de UR e temperatura utilizados nesse experimento foram definidos com o intuito de simular quatro condições de clima: verão presente, verão simulado para o fim do século, inverno presente, inverno simulado para o fim do século. Para UR foi utilizado $70 \%$ para os quatro cenários. Isso se deu por dois motivos, em primeiro lugar porque não se espera grandes variações no que diz respeito a UR para a região, de acordo com os dados de literatura (Ynoue et al., 2014). O segundo motivo consiste no fato de que os fungos serão incoculados em placas de petri com alto teor de umidade para realização do experimento, de forma que a UR não vai ter influência decisiva. Sendo assim definiu-se a UR no valor médio anual para a região, cujo valor é $70 \%$. 
Foi calculada uma temperatura média de inverno e uma temperatura média de verão a partir de dados coletados em três pontos internos da sede da fazenda Vargem Grande (sala do piso principal, sala do piso inferior e sotão) e dois pontos internos da sede da fazenda Catadupa (sala do piso principal e porão), do período de 20/06/2013 a 21/06/2014. Calculou-se média aritmética das temperaturas médias de inverno e de verão de cada ponto. As médias foram arredondadas para um número inteiro. Dessa forma chegou-se aos seguintes valores: temperatura média de verão, $26^{\circ} \mathrm{C}$, temperatura média de inverno: $20^{\circ} \mathrm{C}$.

Foram comparadas as médias sazonais (verão e inverno) de temperatura do mesmo período dos dados coletados nas fazendas com a série histórica do período de 01/01/2008 a 31/12/2014, com o propósito de verificar se o período das coletas foi representativo do clima na região ou foi um período atípico. Como não havia uma diferença significativa entre as médias de temperatura dos dois períodos, não foi necessário fazer ajuste nos dados das fazendas.

Para definir as temperaturas futuras foram utilizados os dados do HADCM3. As previsões para a estação do verão e do inverno em relação ao final do século XIX indicam um aumento de $3^{\circ} \mathrm{C}$ na temperatura média de verão e $4^{\circ} \mathrm{C}$ na temperatura média de inverno (Ynoue, et al, 2014). Assim, definiu-se a temperatura futura de inverno em $24^{\circ} \mathrm{C}$ e a temperatura futura de verão como $29^{\circ} \mathrm{C}$.

Definidas as temperaturas a serem utilizadas, as onze cepas selecionadas nas etapas anteriores foram inoculadas em placas de petri de PDA e colocadas em câmaras climáticas capazes de oferecer controle na ciclagem de UR e temperatura (Paiva et al., 2010). Todas as cepas foram acondicionadas durante 1 dia em uma estufa a $28^{\circ} \mathrm{C}$ e depois colocadas nas câmaras. Cada cepa foi repicada em 20 placas de petri de PDA. As vinte placas foram dividas em quatro câmaras, cada uma com uma temperatura diferente: $20^{\circ} \mathrm{C}$, temperatura média de inverno no Vale Histórico; $24^{\circ} \mathrm{C}$, temperatura futura de inverno; $26^{\circ} \mathrm{C}$, temperatura presente de verão; $29^{\circ} \mathrm{C}$, temperatura futura de verão. A UR relativa foi mantida a 70\%, que é aproximadamente a UR média anual nos microambientes indoor das fazendas.

Após o primeiro dia na estufa foram medidos os diâmetros médios iniciais, que foram o ponto de partida para os registros de crescimento. Depois de colocadas nas câmaras, as cepas foram medidas diariamente. A forma de medida era a seguinte, 
media-se o diâmetro maior e o diâmetro perpendicular a ele, para tentar chegar a um diâmetro médio (BRANCATO, 1953). 


\section{RESULTADOS E DISCUSSÃO}

\subsection{Amostras coletadas e fungos isolados}

A Tabela 5 trás a lista das cepas isoladas que foram mantidas o após o descarte dos fungos não-endófitos (oportunistas) e os locais de coleta das amostras de madeira.

Tabela 5. Lista das cepas isoladas a partir de amostras de madeiras coletadas em diversos substratos de edificações históricas nos municípios de Areias, Bananal e São José do Barreiro (SJB) no Vale Histórico Paulista. Para cada cepa, estão indicados os resultados dos ensaios bioquímicos de atividade celulolítica (AC), o índice de $\mathrm{AC}$ e as respostas aos testes de atividade ligninolítica, nos casos em que foram realizados (do contrário usou-se o símbolo XXX).

\begin{tabular}{|l|c|c|c|c|c|c|c|}
\hline \multicolumn{1}{|c|}{ Amostra/Local } & Cepas & Endófito & AC & Índice AC & LiP & MnP & T \\
\hline Fazenda São Miguel/SJB & 1 & - & $\mathrm{XXX}$ & $\mathrm{XXX}$ & $\mathrm{XXX}$ & $\mathrm{XXX}$ & $\mathrm{XXX}$ \\
\hline Edificação urbana/Areias & 2 & + & + & 1,69 & + & - & - \\
\hline Fazenda Barra/SJB & 3 & - & $\mathrm{XXX}$ & $\mathrm{XXX}$ & $\mathrm{XXX}$ & $\mathrm{XXX}$ & $\mathrm{XXX}$ \\
\hline Fazenda Barra/SJB & 4 & + & - & $\mathrm{XXX}$ & $\mathrm{XXX}$ & $\mathrm{XXX}$ & $\mathrm{XXX}$ \\
\hline Fazenda Barra/SJB & 5 & + & - & $\mathrm{XXX}$ & $\mathrm{XXX}$ & $\mathrm{XXX}$ & $\mathrm{XXX}$ \\
\hline Edificação urbana/Areias & 6 & + & - & $\mathrm{XXX}$ & $\mathrm{XXX}$ & $\mathrm{XXX}$ & $\mathrm{XXX}$ \\
\hline Edificação urbana/Areias & 7 & + & + & 2 & + & - & - \\
\hline Edificação urbana/Areias & 8 & + & - & $\mathrm{XXX}$ & $\mathrm{XXX}$ & $\mathrm{XXX}$ & $\mathrm{XXX}$ \\
\hline Fazenda Barra/SJB & 9 & + & + & 2 & + & - & - \\
\hline Edificação urbana/SJB & 10 & + & + & 2 & + & - & - \\
\hline Fazenda Catadupa/SJB & 11 & - & $\mathrm{XXX}$ & $\mathrm{XXX}$ & $\mathrm{XXX}$ & $\mathrm{XXX}$ & $\mathrm{XXX}$ \\
\hline Clube dos 200/SJB & 12 & + & + & 1 & + & - & + \\
\hline Clube dos 200/SJB & 13 & - & $\mathrm{XXX}$ & $\mathrm{XXX}$ & $\mathrm{XXX}$ & $\mathrm{XXX}$ & $\mathrm{XXX}$ \\
\hline Edificação urbana/Areias & 14 & - & $\mathrm{XXX}$ & $\mathrm{XXX}$ & $\mathrm{XXX}$ & $\mathrm{XXX}$ & $\mathrm{XXX}$ \\
\hline Edificação urbana/Areias & 15 & - & $\mathrm{XXX}$ & $\mathrm{XXX}$ & $\mathrm{XXX}$ & $\mathrm{XXX}$ & $\mathrm{XXX}$ \\
\hline Fazenda São Miguel/SJB & 16 & - & $\mathrm{XXX}$ & $\mathrm{XXX}$ & $\mathrm{XXX}$ & $\mathrm{XXX}$ & $\mathrm{XXX}$ \\
\hline Fazenda São Miguel/SJB & 17 & - & $\mathrm{XXX}$ & $\mathrm{XXX}$ & $\mathrm{XXX}$ & $\mathrm{XXX}$ & $\mathrm{XXX}$ \\
\hline Fazenda República/SJB & 18 & + & - & $\mathrm{XXX}$ & $\mathrm{XXX}$ & $\mathrm{XXX}$ & $\mathrm{XXX}$ \\
\hline Fazenda República/SJB & 19 & + & + & 1,61 & + & - & + \\
\hline Edificação urbana/Areias & 20 & + & - & $\mathrm{XXX}$ & $\mathrm{XXX}$ & $\mathrm{XXX}$ & $\mathrm{XXX}$ \\
\hline Edificação urbana/Areias & 21 & - & $\mathrm{XXX}$ & $\mathrm{XXX}$ & $\mathrm{XXX}$ & $\mathrm{XXX}$ & $\mathrm{XXX}$ \\
\hline Edificação urbana/Areias & 22 & + & - & $\mathrm{XXX}$ & $\mathrm{XXX}$ & $\mathrm{XXX}$ & $\mathrm{XXX}$ \\
\hline Edificação urbana/Areias & 23 & + & + & $\mathrm{Sem} *$ & + & - & - \\
\hline Edificação urbana/Bananal & 24 & - & $\mathrm{XXX}$ & $\mathrm{XXX}$ & $\mathrm{XXX}$ & $\mathrm{XXX}$ & $\mathrm{XXX}$ \\
\hline Edificação urbana/Bananal & 25 & - & $\mathrm{XXX}$ & $\mathrm{XXX}$ & $\mathrm{XXX}$ & $\mathrm{XXX}$ & $\mathrm{XXX}$ \\
\hline Edificação urbana/Bananal & 26 & - & $\mathrm{XXX}$ & $\mathrm{XXX}$ & $\mathrm{XXX}$ & $\mathrm{XXX}$ & $\mathrm{XXX}$ \\
\hline Edificação urbana/Bananal & 27 & + & - & $\mathrm{XXX}$ & $\mathrm{XXX}$ & $\mathrm{XXX}$ & $\mathrm{XXX}$ \\
\hline Edificação urbana/SJB & 28 & - & $\mathrm{XXX}$ & $\mathrm{XXX}$ & $\mathrm{XXX}$ & $\mathrm{XXX}$ & $\mathrm{XXX}$ \\
\hline Edificação urbana/SJB & 29 & - & $\mathrm{XXX}$ & $\mathrm{XXX}$ & $\mathrm{XXX}$ & $\mathrm{XXX}$ & $\mathrm{XXX}$ \\
\hline Fazenda Catadupa/SJB & 30 & + & + & 2,11 & + & - & - \\
\hline
\end{tabular}




\begin{tabular}{|c|c|c|c|c|c|c|c|}
\hline Edificação urbana/Bananal & 31 & - & $\mathrm{XXX}$ & $\mathrm{XXX}$ & $\mathrm{XXX}$ & $\mathrm{XXX}$ & $\mathrm{XXX}$ \\
\hline Edificação urbana/Bananal & 32 & - & $\mathrm{XXX}$ & $\mathrm{XXX}$ & $\mathrm{XXX}$ & $\mathrm{XXX}$ & $\mathrm{XXX}$ \\
\hline Edificação urbana/Bananal & 33 & + & + & 1,66 & - & - & - \\
\hline Edificação urbana/Bananal & 34 & - & XXX & $\mathrm{XXX}$ & XXX & $\mathrm{XXX}$ & $\mathrm{XXX}$ \\
\hline Edificação urbana/Bananal & 35 & + & + & 2,59 & - & - & - \\
\hline Edificação urbana/Bananal & 36 & - & $\mathrm{XXX}$ & $\mathrm{XXX}$ & $\mathrm{XXX}$ & $\mathrm{XXX}$ & $\mathrm{XXX}$ \\
\hline Edificação urbana/Bananal & 37 & + & + & 1 & + & - & + \\
\hline Edificação urbana/Bananal & 38 & + & + & 2,68 & + & - & + \\
\hline Edificação urbana/Bananal & 39 & + & + & 4,36 & + & - & - \\
\hline Edificação urbana/Bananal & 40 & - & $\mathrm{XXX}$ & $\mathrm{XXX}$ & $\mathrm{XXX}$ & $\mathrm{XXX}$ & $\mathrm{XXX}$ \\
\hline Edificação urbana/Bananal & 41 & + & + & 3,42 & + & - & + \\
\hline Edificação urbana/Bananal & 42 & + & - & $\mathrm{XXX}$ & $\mathrm{XXX}$ & $\mathrm{XXX}$ & $\mathrm{XXX}$ \\
\hline Edificação urbana/Bananal & 43 & - & $\mathrm{XXX}$ & $\mathrm{XXX}$ & XXX & $\mathrm{XXX}$ & $\mathrm{XXX}$ \\
\hline Fazenda Loanda/bananal & 44 & - & $\mathrm{XXX}$ & $\mathrm{XXX}$ & XXX & $\mathrm{XXX}$ & $\mathrm{XXX}$ \\
\hline Fazenda Loanda/bananal & 45 & - & $\mathrm{XXX}$ & $\mathrm{XXX}$ & $\mathrm{XXX}$ & $\mathrm{XXX}$ & $\mathrm{XXX}$ \\
\hline Fazenda Loanda/Bananal & 46 & - & $\mathrm{XXX}$ & $\mathrm{XXX}$ & XXX & $\mathrm{XXX}$ & XXX \\
\hline Fazenda Loanda/Bananal & 47 & + & + & 1,93 & + & - & + \\
\hline Edificação urbana/Bananal & 48 & - & $\mathrm{XXX}$ & $\mathrm{XXX}$ & XXX & XXX & XXX \\
\hline Edificação urbana/Bananal & 49 & - & $\mathrm{XXX}$ & $\mathrm{XXX}$ & XXX & $\mathrm{XXX}$ & $\mathrm{XXX}$ \\
\hline Edificação urbana/Bananal & 50 & + & + & 2 & + & - & - \\
\hline Fazenda Boa Vista/Bananal & 51 & + & + & 2,26 & + & - & + \\
\hline Fazenda Boa Vista/Bananal & 52 & + & + & 2 & + & - & - \\
\hline Fazenda Boa Vista/Bananal & 53 & - & $\mathrm{XXX}$ & $\mathrm{XXX}$ & XXX & XXX & $\mathrm{XXX}$ \\
\hline Fazenda Boa Vista/Bananal & 54 & - & $\mathrm{XXX}$ & $\mathrm{XXX}$ & $\mathrm{XXX}$ & $\mathrm{XXX}$ & $\mathrm{XXX}$ \\
\hline Fazenda Boa Vista/Bananal & 55 & - & XXX & $\mathrm{XXX}$ & $\mathrm{XXX}$ & XXX & XXX \\
\hline Edificação urbana/Bananal & 56 & - & $\mathrm{XXX}$ & $\mathrm{XXX}$ & XXX & $\mathrm{XXX}$ & $\mathrm{XXX}$ \\
\hline Edificação urbana/Bananal & 57 & - & $\mathrm{XXX}$ & $\mathrm{XXX}$ & $\mathrm{XXX}$ & $\mathrm{XXX}$ & $\mathrm{XXX}$ \\
\hline Edificação urbana/Bananal & 58 & - & $\mathrm{XXX}$ & $\mathrm{XXX}$ & $\mathrm{XXX}$ & $\mathrm{XXX}$ & $\mathrm{XXX}$ \\
\hline Edificação urbana/Bananal & 59 & + & + & 2,33 & + & - & - \\
\hline Edificação urbana/Bananal & 60 & - & $\mathrm{XXX}$ & XXX & XXX & $\mathrm{XXX}$ & $\mathrm{XXX}$ \\
\hline Edificação urbana/Bananal & 61 & - & $\mathrm{XXX}$ & $\mathrm{XXX}$ & $\mathrm{XXX}$ & $\mathrm{XXX}$ & $\mathrm{XXX}$ \\
\hline Edificação urbana/Bananal & 62 & + & + & 2,21 & + & - & + \\
\hline Edificação urbana/Bananal & 63 & + & + & 2,68 & + & - & + \\
\hline Edificação urbana/Bananal & 64 & + & + & 2,98 & + & - & + \\
\hline Edificação urbana/Bananal & 65 & - & $\mathrm{XXX}$ & $\mathrm{XXX}$ & $\mathrm{XXX}$ & XXX & XXX \\
\hline Edificação urbana/Bananal & 66 & - & $\mathrm{XXX}$ & $\mathrm{XXX}$ & $\mathrm{XXX}$ & $\mathrm{XXX}$ & $\mathrm{XXX}$ \\
\hline Edificação urbana/Bananal & 67 & - & $\mathrm{XXX}$ & $\mathrm{XXX}$ & $\mathrm{XXX}$ & $\mathrm{XXX}$ & $\mathrm{XXX}$ \\
\hline Edificação urbana/Bananal & 68 & - & $\mathrm{XXX}$ & $\mathrm{XXX}$ & $\mathrm{XXX}$ & $\mathrm{XXX}$ & $\mathrm{XXX}$ \\
\hline Edificação urbana/Bananal & 69 & + & - & $\mathrm{XXX}$ & $\mathrm{XXX}$ & $\mathrm{XXX}$ & $\mathrm{XXX}$ \\
\hline Edificação urbana/Bananal & 70 & - & $\mathrm{XXX}$ & $\mathrm{XXX}$ & XXX & $\mathrm{XXX}$ & $\mathrm{XXX}$ \\
\hline Edificação urbana/Bananal & 72 & - & $\mathrm{XXX}$ & $\mathrm{XXX}$ & $\mathrm{XXX}$ & $\mathrm{XXX}$ & $\mathrm{XXX}$ \\
\hline Edificação urbana/Bananal & 73 & - & $\mathrm{XXX}$ & $\mathrm{XXX}$ & XXX & $\mathrm{XXX}$ & $\mathrm{XXX}$ \\
\hline Edificação urbana/Bananal & 74 & + & - & $\mathrm{XXX}$ & $\mathrm{XXX}$ & $\mathrm{XXX}$ & $\mathrm{XXX}$ \\
\hline Edificação urbana/Bananal & 75 & + & - & $\mathrm{XXX}$ & $\mathrm{XXX}$ & $\mathrm{XXX}$ & $\mathrm{XXX}$ \\
\hline Edificação urbana/Bananal & 76 & - & $\mathrm{XXX}$ & $\mathrm{XXX}$ & $\mathrm{XXX}$ & $\mathrm{XXX}$ & $\mathrm{XXX}$ \\
\hline
\end{tabular}

* Não foi possível obter um valor quantitativo por causa do excessivo crescimento do fungo 
Tipicamente, foram extraídos de 1 a 5 fungos de cada amostra de madeira, o que não significa necessariamente que os agentes de biodeterioração se restrinjam às espécies que foram extraídas, já que é sabido que o procedimento adotado apresenta uma limitação muito grande com relação ao isolamento das efetivas espécies de fungos presentes num determinado substrato. Com isso, os dados obtidos não permitiram uma avaliação do grau de biodiversidade nos substratos colhidos, nem esse tipo de processo faria realmente sentido, haja vista a heterogeneidade dos locais de coleta dentro das edificações (vigas externas, vigas internas, colunas externas, colunas internas, madeiras de acabamento) que foram escolhidas em função da efetiva disponibilidade por parte dos proprietários dos imóveis e das diversas condições de conservação das madeiras, bem como da variedade geográficas dos pontos de amostragem, incluindo diversos meios urbanos e rurais. Essa atividade permitiu, de qualquer forma, a montagem de um primeiro banco de fungos efetivamente presentes em madeiras na região de estudo e foi a partir desse banco que foram testadas as hipóteses dessa pesquisa quanto à questão do efeito das variáveis climáticas.

\subsection{Avaliação da atividade enzimática dos fungos isolados}

Foram testadas trinta e quatro cepas nos ensaios de atividade celulolítica e na Tabela 5 pode-se ver os resultados. Cepas com resultado positivo são capazes de degradar celulose (Figura 18). Na coluna da direita há o índice de atividade enzimática relativa. A cepa 23 teve resultado positivo, porém, o calculo do índice não pode ser realizado, já que a o halo tomou conta de toda a área da placa. Aproximadamente dois terços das cepas obtiveram resultado positivo nos ensaios para celulase. O menor índice foi 1,00 e maior foi 4,36, com uma média de 2,22, o que índica tipicamente alta atividade celulolítica nas espécies coletadas.

As cepas que produziram resultado positivo nessa etapa foram utilizadas nos ensaios de atividade ligninolítica. Na Tabela 5, pode-se observar os resultados dos ensaios para a enzima lignina peroxidase. Das vinte e duas cepas submetidas a esse ensaio, vinte proporcionaram um resultado positivo. Entretanto é importante notar que esse ensaio pode produzir com certa frequência falsos positivos, principalmente devido a adsorção do corante pelas cepas que pode ser confundido com sua oxidação, já que 
nos dois casos o meio de cultura parece mais claro. Nessa avaliação, o resultado do ensaio de MnP não permitiu uma claro avanço já que todas as cepas obtiveram resultado negativo. Dessa forma, passou-se ao teste de tanase, no qual um total de nove cepas apresentaram resultado positivo.
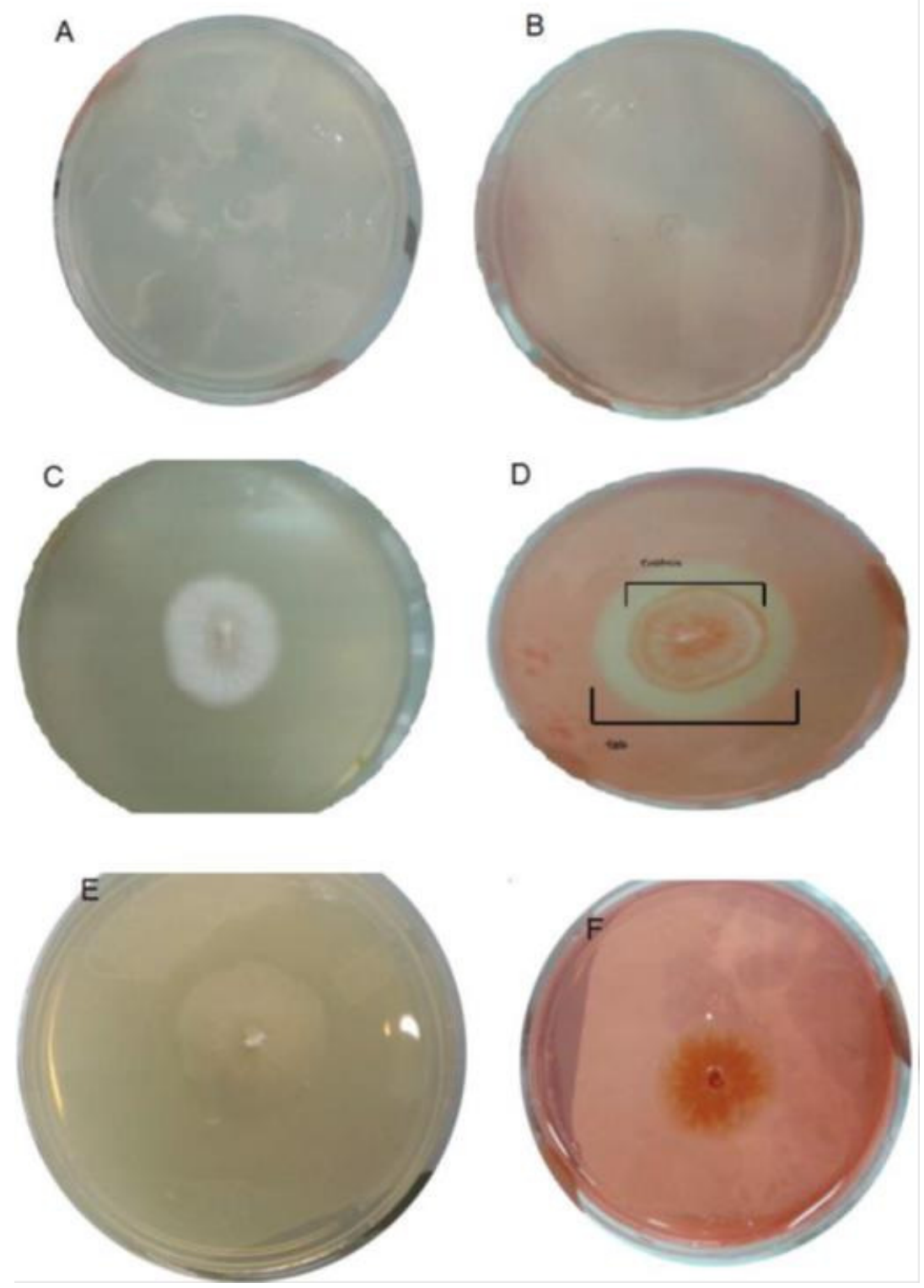

Figura 18. Exemplos de ensaio de atividade celulolítica. (A) Placa controle sem corante. (B) Placa controle sem corante, após lavagem com solução $1 \mathrm{M}$ de $\mathrm{NaCl}$. (C) Cepa 59. Placa antes da aplicação do vermelho de congo. (D) Cepa 59. Resultado positivo. Foro do meio de cultura com corante após lavagem. Os colchetes indicam os diâmetros do halo e da colônia que serviram para determinar o índice AC. (E) Cepa75. Antes da aplicação do vermelho de congo. (F) Cepa 75. Placa com corante vermelho de congo, após lavagem. Resultado negativo. Observa-se que não houve formação de halo. 


\subsection{Identificação por taxonomia}

Das onze cepas que foram selecionadas para o experimento em micro-clima controlado, quatro foram estudadas por meio de observações em microscópio óptico em função de suas características morfológicas. As amostras foram preparadas com azul de lactofenol. Duas delas puderam ser caracterizadas ao nível de gênero, duas apenas ao nível de filo, como foi destacado na Tabela 6. Na Figura 19, estão mostradas fotográficas que permitiram a identificação da cepa 62.

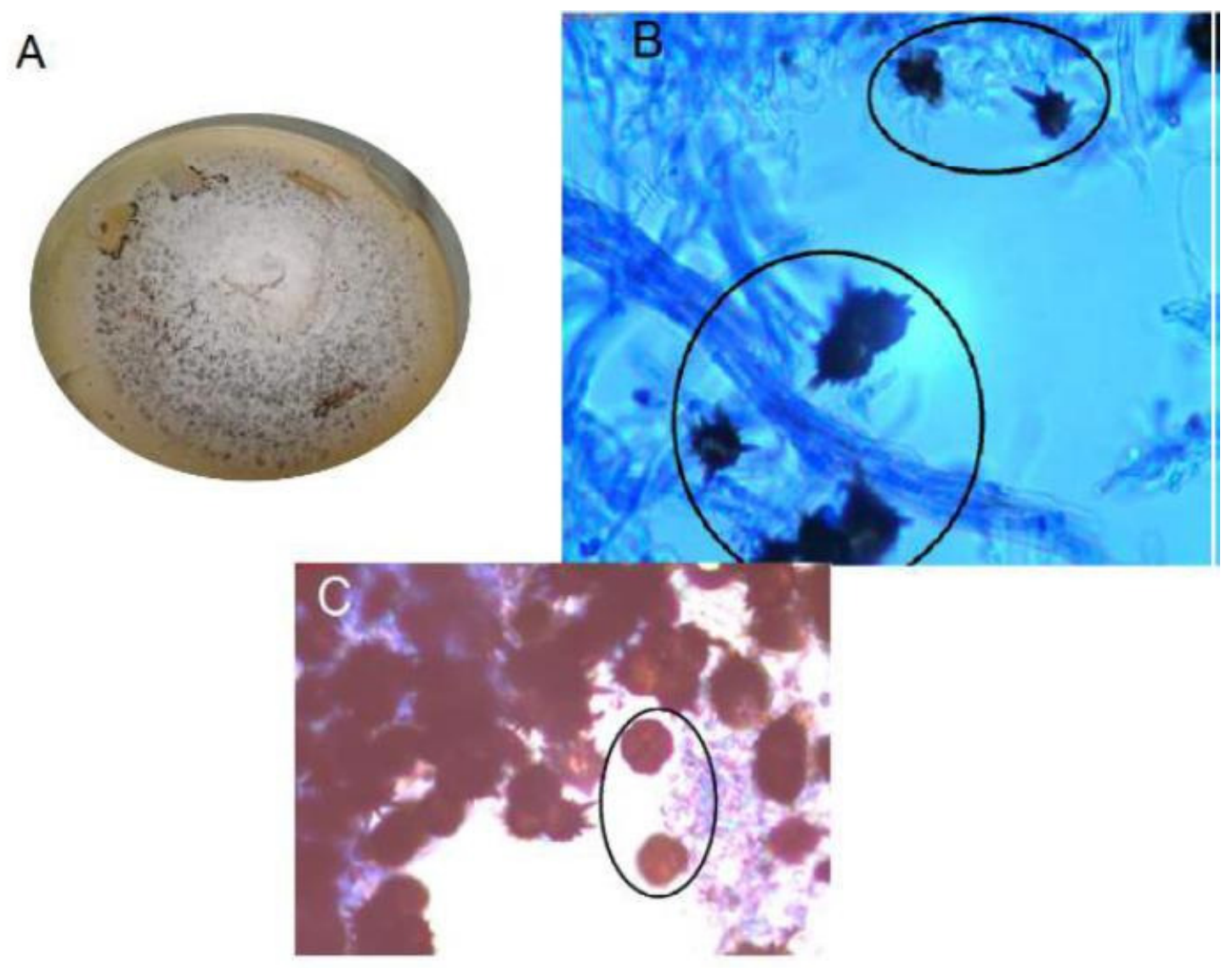

Figura 19. Cepa 62, Spegazzinia tessarthra. (A) Foto da colônia em placa de petri. (B) Imagem de microscópio: em destaque conídios do tipo septado. (C) Imagem de microscópio: em destaque conídios lisos com quatro células. 
Tabela 6. Síntese das informações de identificação dos fungos por biologia molecular (64, 51, 37, 19 e 47) e por (12, 50, 62 e 63)

\begin{tabular}{|c|c|c|c|c|c|}
\hline Cepa & Gênero & Espécie & Score & $\begin{array}{c}\text { GenBank } \\
\text { accessation } \\
\text { number }\end{array}$ & Características ecológicas \\
\hline \multirow[t]{2}{*}{64} & Entonaema & $\begin{array}{l}\text { Entonaema } \\
\text { liquescens }\end{array}$ & $94 \%$ & AY616686 & $\begin{array}{l}\text { Os indivíduos dessa família são encontrados nas regiões temperadas e tropicais do globo. Esses fungos podem ser } \\
\text { encontrados em madeira, sementes, frutos, folhas e até em ninhos de insetos. A maioria das espécies degrada madeira e } \\
\text { muitas são patôgenas de plantas.A cepa foi identificada como pertencente à espécie Entonaema Liquensens ou ao gênero } \\
\quad \text { Nodulisporium. } \\
\text { Os Entonaema Linquesces são saprófitos de madeiraas decíduas. Os fungos do gênero Nodulisporium são endófitos de } \\
\text { plantas lenhosas tropicais }\end{array}$ \\
\hline & Nodulisporium & - & $94 \%$ & KC881195 & \\
\hline \multirow[b]{3}{*}{51} & Colletotrichum & $\begin{array}{l}\text { Colletotrichum } \\
\text { gloeosporioides }\end{array}$ & $96 \%$ & HQ645078 & $\begin{array}{l}\text { Espécie patogênica da família dos Glomerellaceae,causadora da anthracnose em culturas como abacateiro, cafeeiro, } \\
\text { macieira etc. O Colletotrchum gloesporioides é a estágio anamorfo do Glomerella cingulata. }\end{array}$ \\
\hline & Neopesltalotiopsis & - & $96 \%$ & KR493552 & \\
\hline & Pestalotiopsis & - & $96 \%$ & KT224867 & $\begin{array}{l}\text { A família dos Amphisphaeriaceae é principalmente encontrada em partes da Nova Zelândia, América do Sul, Ásia e } \\
\text { Europa. Muitas espécies dessa família são parasitas de plantas, como as do gênero Pestalotiopsis que é um grupo rico } \\
\text { em espécies amplamente distribuído em regiões tropicais e temperadas. As espécies do gênero Pestalotiopsis são em } \\
\text { grande parte fito patogênicas podendo produzir uma grande variedade doenças nas plantas. Também são } \\
\text { muito isoladasdas espécies endófitas e srprófitas. Maharachchikumbura et. al. (2014) combinando morfologia e dados } \\
\text { de DNA segregaram dois novos gêneros a partir dos Pestalotiopsis: Neopestalotiopsis e Pseudopestalotiopsis. }\end{array}$ \\
\hline \multirow[b]{2}{*}{37} & Asporospora & $\begin{array}{l}\text { Aporospora } \\
\text { terricola }\end{array}$ & $100 \%$ & KC292905 & - \\
\hline & Microdiplodia & $\begin{array}{l}\text { Microdiplodia } \\
\text { miyakei }\end{array}$ & $100 \%$ & KR912326 & $\begin{array}{l}\text { Espécie da família dos Botryosphaeriaceae. Os fungos dessa família são patógenos. Podem causar podridão de frutos e } \\
\text { morte progressiva de ramos. Também podem atuar como saprófitos de árvores lenhosas. (PHILPS et. al., 2008) }\end{array}$ \\
\hline
\end{tabular}




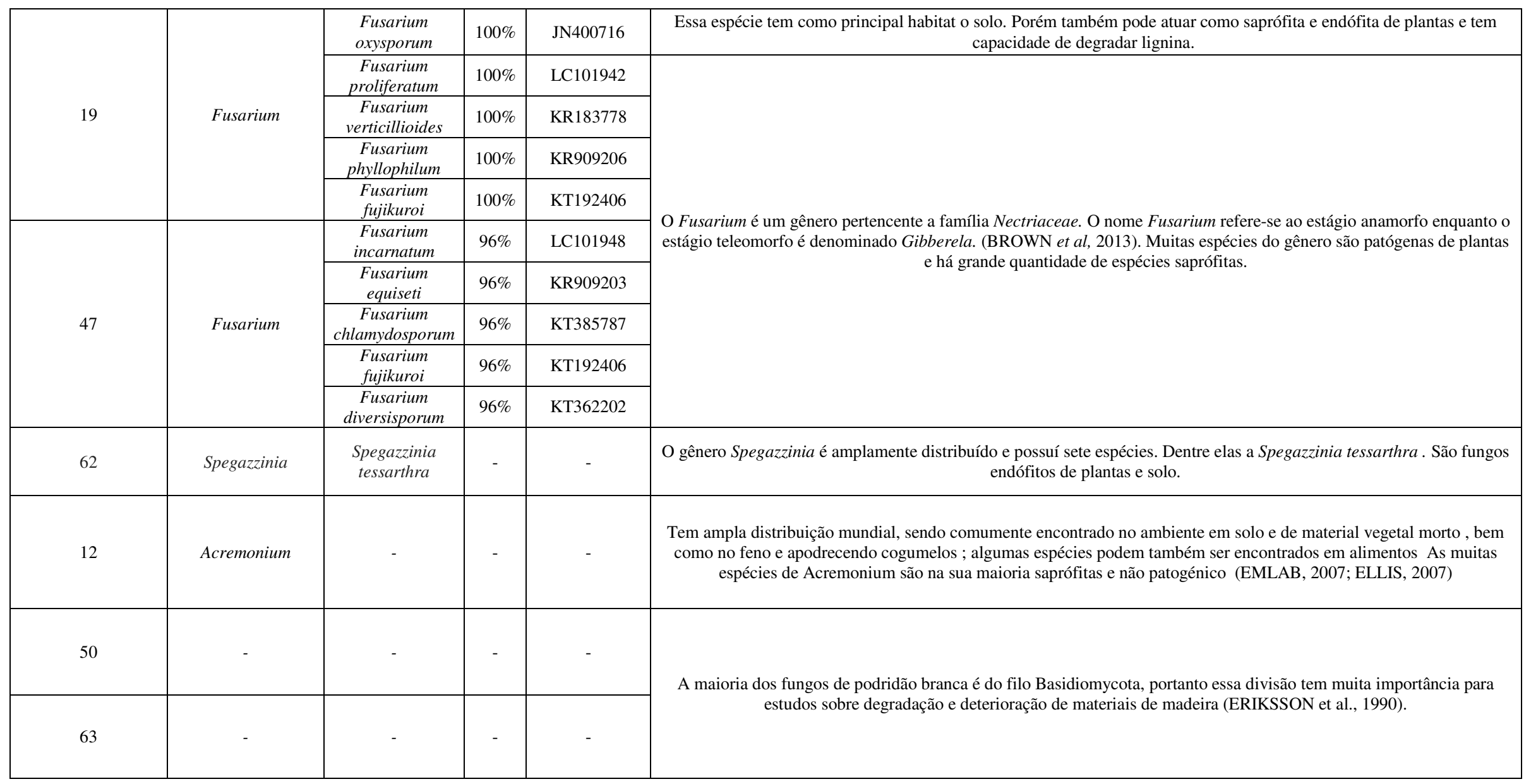


Após amplificação dos fragmentos de DNA na região ITS e NS, foi feita a avaliação da integridade e tamanho do material amplificado por eletroforese em gel de agarose $1 \%$ em TAE. A Figura 20 mostra que foram amplificados fragmentos com massa molecular entre 800 e 900 pb para os dois conjuntos de primers usados, porém, somente o material amplificado com o primer ITS apresentou grau de pureza que permitisse o procedimento para sequenciamento.

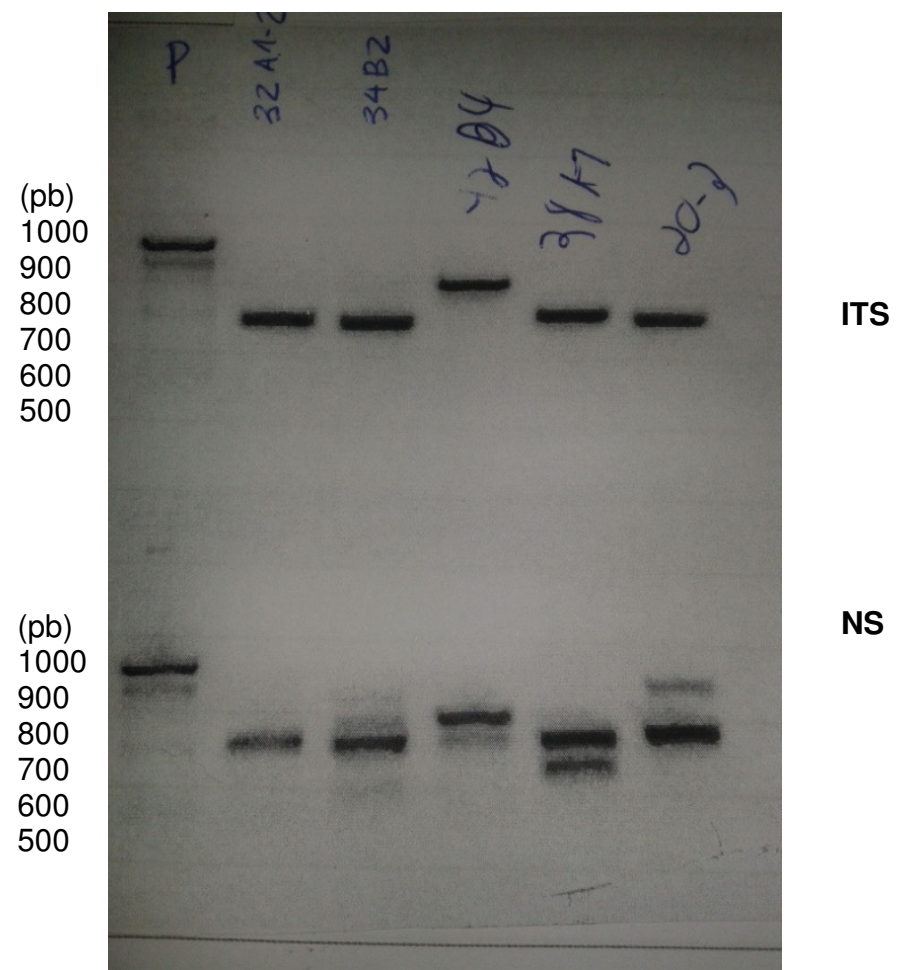

Figura 20. Gel para avaliação do DNA amplificado usando-se os primers ITS e NS, respectivamente. Padrão de massas moleculares 100 bp Ladder.

Na Figura 21, observa-se que em uma segunda amplificação, o produto amplificado com o primer NS apresentou maior grau de pureza, sendo observadas bandas adicionais ao produto com massa molecular de aproximadamente $800 \mathrm{pb}$. 


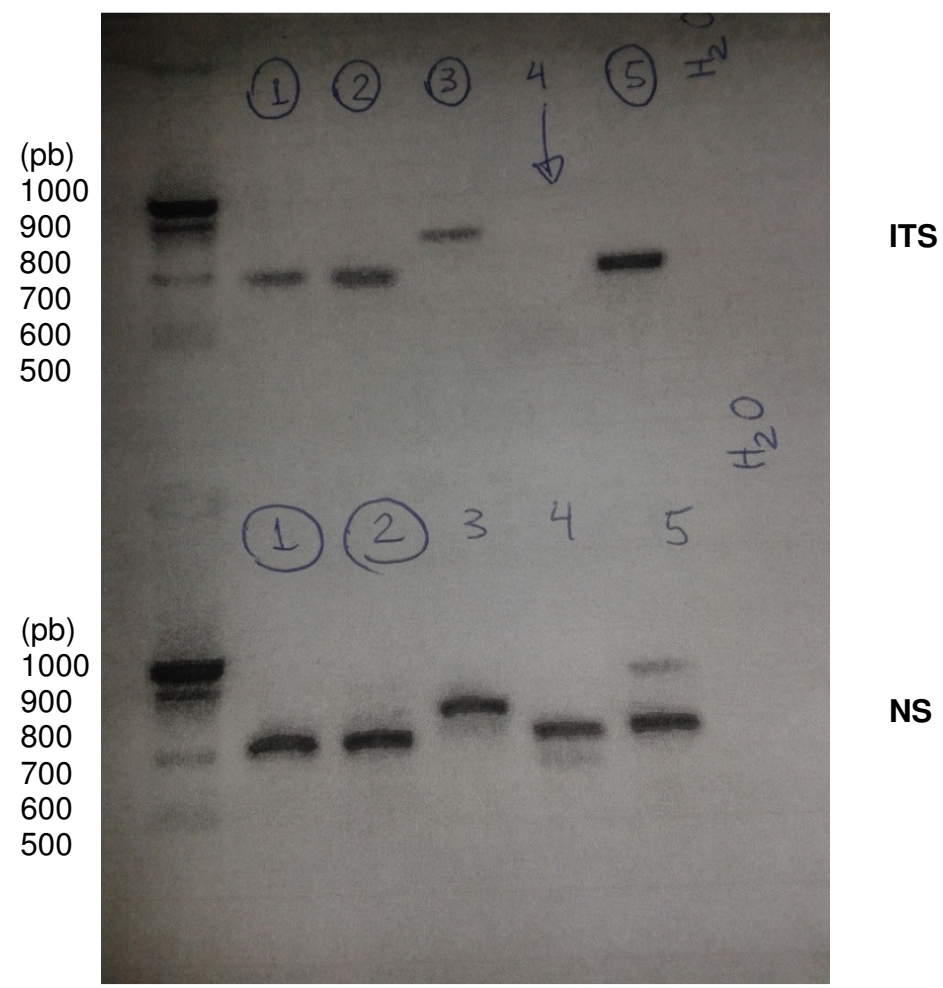

Figura 21. Gel para avaliação do DNA amplificado usando-se os primers ITS e NS, respectivamente. Padrão de massas moleculares 100 bp Ladder.

Após amplificação dos fragmentos de DNA nas regiões de interesse e purificação do material, o mesmo foi sequenciado por eletroforese capilar, segundo a técnica de Sanger.

O sequenciamento do DNA das diferentes cepas permitiu a comparação das sequências às disponíveis em bases de dados especializadas (Strandardnucleotide BLAST). Nessas comparações, é fornecido um índice de similaridade (scores) entre as sequências, o qual é expresso em termos de porcentagem.

Na Tabela 6, estão mostradas as espécies (ou gêneros) mais prováveis (com maior "score") para cada uma das cinco cepas que foram submetidas aos procedimentos de identificação molecular.

Os gêneros encontrados foram Entonaema, Nodulisporium, Colletotrichum, Neopesltalotiopsis, Pestalotiopsis, Asporospora, Microdiplodia, Fusarium, Spegazzinia e Acremonium, sendo possível, no caso de algumas cepas, sugerir uma ou mais espécies, em geral, geneticamente relacionadas. 
O fato de cada cepa ter sido relacionada com mais de uma espécie ou gênero, aponta a necessidade de se usar um conjunto de primers que contemple outras regiões do genoma dos fungos, conforme já mostrado por MARTIN e RYGIEWICZ (2005).

Entretanto, os resultados aqui apresentados já representam uma primeira etapa de uma investigação dessa natureza e que poderá culminar na melhor caracterização dos fungos, em conjunto com os dados morfológicos e bioquímicos.

Além disso, essa abordagem deverá servir de base para melhor entendimento das relações que se estabelecem entre os fatores abióticos (o ambiente), o substrato e o agente biológico, bem como as relações entre os próprios fungos que colonizam um dado material.

É preciso considerar, ainda que, todo o processo de identificação e caracterização de microorganismos, inclusive a etapa de biologia molecular, foi baseado em métodos dependentes de cultura. Esse tipo de abordagem, que é tradicionalmente utilizado na identificação de microorganismos que colonizam bens culturais, tem limitações.

Os métodos dependentes de cultura são uma poderosa ferramenta para identificação e caracterização de microorganismos, porém apenas podem acessar entre 0,1 e $1 \%$ dos organismos presentes nos ambientes naturais. Cerca de $99 \%$ dos organismos se apresentam no meio ambiente em estado de anabiose, mantendo-se viáveis, mas incultiváveis (VBCN - being viable but non-culturable) (OTLEWSKA et al., 2014).

Os organismos incultiváveis podem ser de três tipos: (i) organismos obrigatoriamente parasitário ou simbiótico, (ii) espécies conhecidas, nas quais a identificação por meios de métodos dependentes de cultivo mostraram-se inadequados, (iii) espécies desconhecidas que nunca foram cultivadas por conta da falta de métodos adequados. (OTLEWSKA et al., 2014).

As dificuldades de isolamento e identificação desses organismos representam uma significativa redução da análise da biodiversidade dos micro-organismos endófitos de bens culturais. Por conta disso, alguns pesquisadores propuseram soluções envolvendo técnicas independentes de cultivo. (OTLEWSKA et al., 2014).

Nesse contexto, tem-se aumentado a atenção voltada para um novo campo da ciência, a metagenômica, que, na última década, revolucionou as ciências biológicas, incluindo a microbiologia. 
A metagenômica é o estudo do material genético isolado diretamente de uma amostra ambiental, possibilitando a análise de todos os micro-organismos de uma determinada amostra, inclusive os incultiváveis. (OTLEWSKA et al., 2014).

É necessário pontuar, portanto, que para o desenvolvimento do presento trabalho, a metagenômica teria sido uma ferramenta bastante útil e teria aprimorado a caracterização dos micro-organismos presentes nas amostras de madeira. $\mathrm{O}$ uso apenas de técnicas dependentes de cultivo provavelmente estreitou as possibilidades de reconhecimento de organismos nocivos presentes nas edificações estudadas.

\subsection{Avaliação das condições microclimáticas nos ambientes interiores de edificações históricas}

Conforme antecipado, as avaliações das condições microclimáticas indoor foram realizadas a partir dos dados de monitoramento em escala anual da temperatura e da umidade relativa de quatro edificações históricas do Vale Histórico Paulista. Na Fazenda São Francisco, foram avaliados dois ambientes no nível inferior da casa, dois no nível principal e o espaço abaixo do telhado (sótão). Todos os locais no interior da fazenda apresentam níveis médios de umidade relativa significativamente inferiores ao ambiente externo (Tabela 7), contudo considerando que as condições externas são de elevada umidade relativa média, os valores indoor (mediamente todos $>65 \%$ ) também podem ser considerados altos e favoráveis ao desenvolvimento de fungos.

Tabela 7. Quadro das condições médias de umidade relativa nos locais interiores da Fazenda São Francisco

\begin{tabular}{|c|c|c|c|c|c|}
\hline & $\begin{array}{l}\text { Nivel principal: } \\
\text { corredor }\end{array}$ & $\begin{array}{l}\text { Nivel principal } \\
\text { quarto de dormir }\end{array}$ & Sótão & $\begin{array}{l}\text { Nivel inferior: sala } \\
\text { climatizada }\end{array}$ & $\begin{array}{l}\text { Nivel inferior: sala } \\
\text { não climatizada }\end{array}$ \\
\hline $\begin{array}{c}\text { Valores médios anuais } \\
(\%)\end{array}$ & 65,9 & 71,1 & 67,2 & 72,1 & 72,4 \\
\hline $\begin{array}{c}\text { Médias das diferenças } \\
\text { indoor/outdoor }(\%)\end{array}$ & $-15,7$ & $-10,5$ & $-14,3$ & $-9,5$ & $-9,1$ \\
\hline
\end{tabular}

Buscando compreender melhor a dinâmica da umidade relativa nesses ambientes, a partir das médias diárias de temperatura e umidade relativa foi calculada a série das médias diárias de razão de mistura $(\mathrm{RM})$, grandeza que corresponde à efetiva 
quantidade de vapor de água na atmosfera em g por massa de ar seco. Essa abordagem, sugerida por Camuffo (1998), permite obter valores absolutos de vapor de água (e, portanto, não umidade relativa que é uma grandeza que depende da temperatura) e sua comparação com os valores de razão de mistura externos possibilita verificar se predominam, no local considerado, fontes ou sumidouros de vapor de água. Por fontes entende-se qualquer elemento (paredes porosas, tubulação de água, aparelhos umidificadores) que proporcione ingresso de água e, portanto, acúmulo frente à linha base constituída pelo mesoclima local. As séries temporárias de razão de mistura (Figura 23) podem ser convenientemente calculadas pela fórmula empírica de Magnus proposta por Camuffo (1998):

$$
R M=\frac{37,95 \times U R \times 10^{\frac{7,5 \times T}{(237,3+T)}}}{P}
$$

onde a umidade relativa (UR) é expressa em \%, a temperatura (T) em ${ }^{\circ} \mathrm{C}$ e a pressão (P) em $\mathrm{hPa}$, sendo $\mathrm{RM}$ retornada em $\mathrm{g} \mathrm{kg}^{-1}$.

É significativo o fato de haver as menores diferenças na área inferior da casa (portanto, maiores níveis de UR), ainda que a temperatura média nesses locais seja somente décimos de graus inferior à dos outros ambientes da casa. Provavelmente, isso se deve ao ingresso de vapor de água do chão de terra e, do ponto de vista da conservação da madeira, é um aspecto importante já que nessas salas estão presentes as vigas de sustentação do pavimento superior e do próprio assoalho das salas principais do casarão. No caso específico da Fazenda SF, há de se levar em consideração o uso do nível inferior da fazenda para atividades culturais e de preservação de artefatos históricos. 

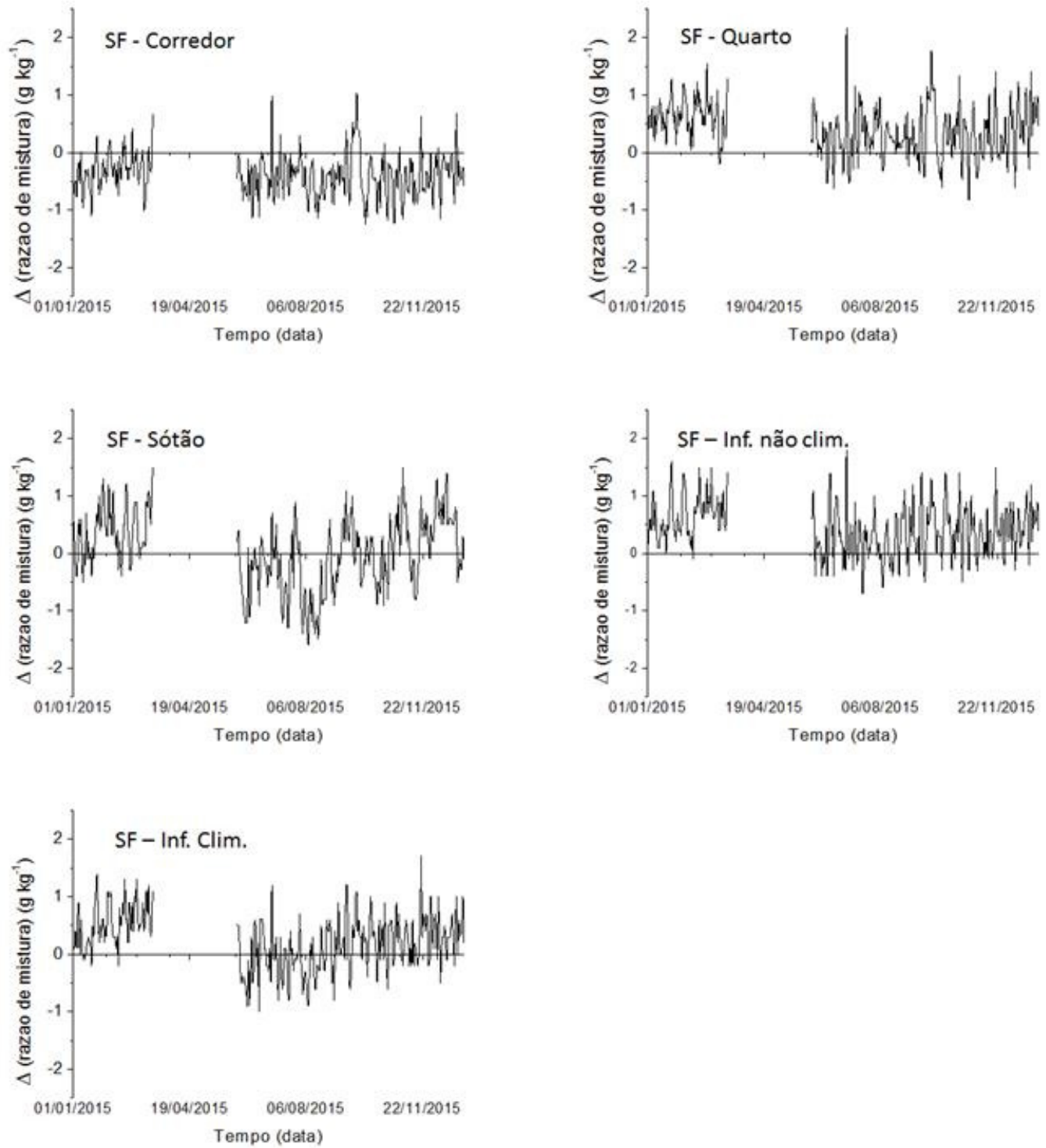

Figura 23. Séries temporais das diferenças entre a razão de mistura do vapor $\left(\mathrm{g} \mathrm{kg}^{-1}\right)$ nos locais indoor e no ambiente outdoor na Fazenda São Francisco no período de 1/1/2015 a 31/12/2015. 
Tabela 8. Razão de mistura do vapor de água $\left(\mathrm{g} \mathrm{kg}^{-1}\right)$ nos locais indoor da São Francisco. Valor da razão de mistura média anual no ambiente exterior: $13,6 \mathrm{~g} \mathrm{~kg}^{-1}$.

\begin{tabular}{|c|c|c|c|c|c|}
\hline & $\begin{array}{l}\text { Nivel principal: } \\
\text { corredor }\end{array}$ & $\begin{array}{l}\text { Nivel principal } \\
\text { quarto de dormir }\end{array}$ & Sótão & $\begin{array}{l}\text { Nivel inferior: sala } \\
\text { climatizada }\end{array}$ & $\begin{array}{l}\text { Nivel inferior: sala } \\
\text { não climatizada }\end{array}$ \\
\hline $\begin{array}{l}\text { Valores médios anuais } \\
(\%)\end{array}$ & 13,2 & 14,0 & 13,6 & 13,8 & 14,0 \\
\hline $\begin{array}{l}\text { Médias das diferenças } \\
\text { indoor/outdoor (\%) }\end{array}$ & $-0,4$ & 0,4 & 0,0 & 0,2 & 0,4 \\
\hline
\end{tabular}

Com relação à temperatura (Tabela 9), em todos os ambientes indoor a temperatura média anual é maior do que a temperatura média outdoor $\left(21,6{ }^{\circ} \mathrm{C}\right.$ em 2015). A amplitude dessa diferença varia entre $2,2-2,4{ }^{\circ} \mathrm{C}$ nos ambientes inferiores da casa até $3,3{ }^{\circ} \mathrm{C}$ no sótão, isto é, o sótão tem uma temperatura média anual de quase 25 ${ }^{\circ} \mathrm{C}$.

Olhando para as diferentes estações do ano, comparou-se os dados dos meses de junho a agosto e do período de janeiro a fevereiro acrescido do mês de dezembro de 2015. As diferenças indoor/outdoor se mantêm positivas em ambos os casos, mas são mais baixas e com menor variabilidade entre os distintos locais do casarão no inverno $\left(2,0\right.$ a $\left.2,5{ }^{\circ} \mathrm{C}\right)$ do que no verão $\left(2,0\right.$ a $\left.4,2{ }^{\circ} \mathrm{C}\right)$. Nesse comportamento, o sótão sempre desempenha um papel importante, pois está sujeito a maior aquecimento durante o dia e nos meses de maior insolação. Esse comportamento pode ser observado nas Figuras 24 e 25 que representam os perfis de temperaturas i) médias no mês de janeiro e de agosto (2015) e ii) horárias em sete dias escolhidos como representativos nos mesmos meses, respectivamente.

No verão, o sótão alcança sistematicamente temperaturas médias sistematicamente superiores às do ambiente exterior e às dos outros ambientes da casa, às vezes com diferenças médias diárias de $2-3{ }^{\circ} \mathrm{C}$ com relação aos outros ambientes e até $7{ }^{\circ} \mathrm{C}$ com relação ao ambiente exterior. Olhando para o perfil das variações horárias, percebe-se que os ciclos diários desse espaço apresentam características bastante distintas das dos demais locais. Uma análise, ainda que superficial, sobre esse comportamento, leva a constatar que o espaço do sótão, no verão, nunca consegue realmente resfriar acompanhando as quedas de temperatura noturnas da atmosfera outdoor, diferente das salas dos níveis inferiores a ele: os mínimos diários ocorrem tipicamente por volta das 7-8 horas da manhã, quando com a retomada da incidência solar o processo é invertido e o aquecimento recomeça. No inverno a situação é 
amenizada, com menores índices de aquecimento, mas sempre com temperaturas acima do valor externo no intervalo de $1-3{ }^{\circ} \mathrm{C}$.

Nas salas de vivência e nos locais do piso inferior, os ciclo dia-noite são mais regulares e refletem a capacidade da edificação de amenizar, com a inércia térmica das estruturas laterais da casa - principais barreiras contra a pressão climática exercida pelo ambiente externo -, os picos de aumento e queda de temperatura. As flutuações regulares ao redor do zero indicam que tais espaços realmente atuam como buffer das alterações externas. Contudo, tanto no verão como, sobretudo, no inverno eles atuam melhor na retenção de calor, o que possivelmente seja um dos objetivos buscados do ponto de vista do conforto térmico das pessoas, mas que certamente atua em prol do desenvolvimento de agentes de biodeterioração (em que pese, nisso, o efeito da temperatura na umidade relativa no contexto considerado).

Tabela 9. Quadro das condições médias de temperatura nos locais interiores da Fazenda São Francisco

\begin{tabular}{|c|c|c|c|c|c|}
\hline & $\begin{array}{l}\text { Nivel principal } \\
\text { corredor }\end{array}$ & $\begin{array}{l}\text { Nivel principal } \\
\text { quarto de dormir }\end{array}$ & Sotão & $\begin{array}{l}\text { Nivel inferior: sala } \\
\text { climatizada }\end{array}$ & $\begin{array}{l}\text { Nivel inferior: sala } \\
\text { não climatizada }\end{array}$ \\
\hline $\begin{array}{l}\text { Valores médios anuais } \\
\text { em } 2015 \text { (C) }\end{array}$ & 24,6 & 24,3 & 24,9 & 23,8 & 24,0 \\
\hline $\begin{array}{l}\text { Médias das diferenças } \\
\text { indoor outdoor }\left({ }^{\circ} \mathrm{C}\right)\end{array}$ & $+3,0$ & $+2,7$ & $+3,3$ & $+2,2$ & $+2,4$ \\
\hline $\begin{array}{l}\text { Valores médios em } 2015 \\
\text { (C)): meses de jun-ago }\end{array}$ & 20,9 & 20,6 & 20,8 & 21,0 & 20,9 \\
\hline $\begin{array}{l}\text { Médias das diferenças } \\
\left.\text { indoor outdoor }{ }^{\circ} \mathrm{C}\right) \text { : } \\
\text { meses de jun-ago }\end{array}$ & $+2,4$ & $+2,0$ & $+2,2$ & $+2,5$ & $+2,4$ \\
\hline $\begin{array}{l}\text { Valores médios em } 2015 \\
\text { ('C): meses de dez-fev }\end{array}$ & 27,4 & 27,2 & 28,0 & 25,8 & 26,2 \\
\hline $\begin{array}{l}\text { Médias das diferenças } \\
\text { indoor/outdoor }(\mathrm{C}) \text { : } \\
\text { meses de dez-fev }\end{array}$ & $+3,6$ & $+3,3$ & $+4,2$ & $+2,0$ & $+2,4$ \\
\hline
\end{tabular}




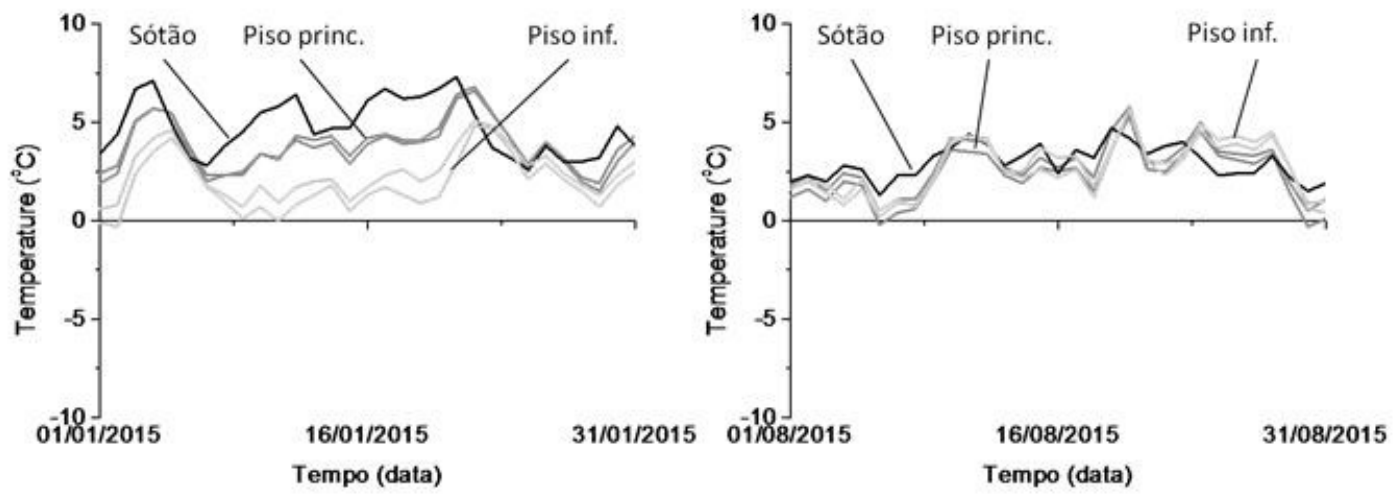

Figura 24. Detalhamento da variação das temperaturas médias diárias medidas em cinco locais do casarão em dois períodos climaticamente distintos: janeiro (ESQ.) e agosto (DIR.) na fazenda São Francisco. Nas plotagem, foram usados valores diferenciais frente às temperaturas médias diárias externas.
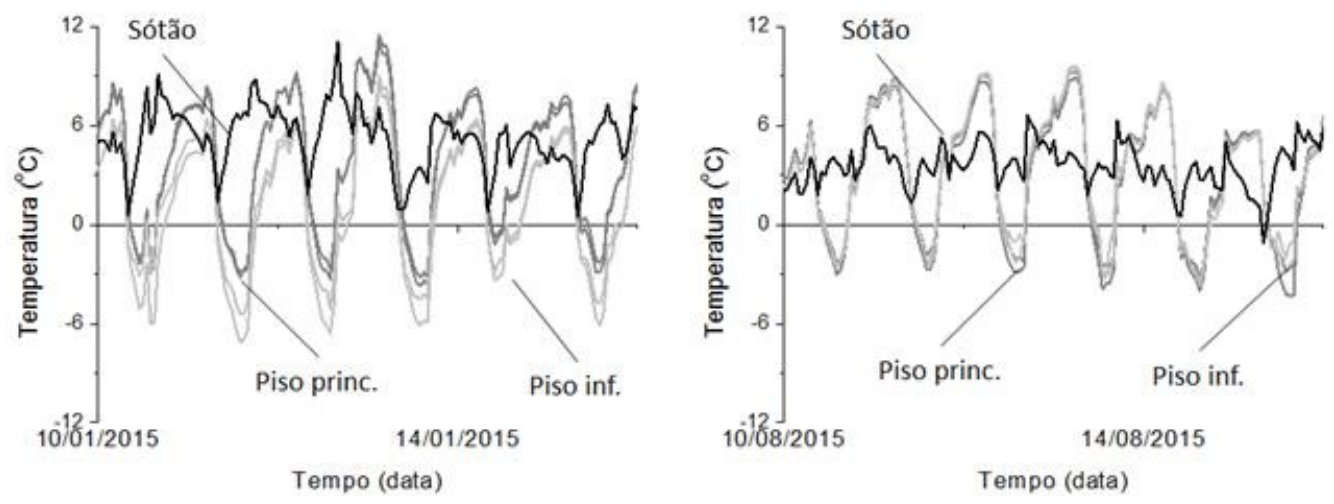

Figura 25. Detalhamento da variação das temperaturas horárias medidas em cinco locais do casarão em dois períodos climaticamente distintos: janeiro (ESQ.) e agosto (DIR.) na fazenda São Francisco. Nas plotagem, foram usados valores diferenciais frente às temperaturas médias diárias externas.

Na Fazenda São Miguel, como informado na parte de Materiais e métodos, a identificação dos locais monitorados na fazenda foi perdida. A reconstrução da associação entre os dados e os locais foi baseada na análise dos perfis de temperatura e, por esse motivo, os nomes dos locais estão indicados entre parênteses nas tabelas.

A Fazenda SM foi monitorada no mesmo período que a SF e apresenta condições de UR mais drásticas, isto é, diferenças da média com relação ao ambiente externo compreendidas entre 6,7 e 10,2 unidades percentuais. Isso, nos valores condições plenamente favoráveis ao desenvolvimento de agentes de biodeterioração, de acordo com a literatura sobre o assunto. 
Tabela 10. Quadro das condições médias de umidade relativa nos locais interiores da Fazenda São Miguel.

\begin{tabular}{|c|c|c|c|c|c|} 
& 76 (Sala vivência) & 82 (Armazém) & 84 (Sala vivência) & 85 (Sala vivência) & 00 (Sótão) \\
\hline $\begin{array}{c}\text { Valores médios anuais } \\
\text { em 2015 (\%) }\end{array}$ & 71,4 & 73,6 & 72,4 & 74,9 & 74,4 \\
\hline $\begin{array}{c}\text { Médias das diferenças } \\
\text { indoor/outdoor }(\%)\end{array}$ & $-10,2$ & $-8,0$ & $-9,1$ & $-6,7$ & $-7,1$ \\
\hline
\end{tabular}

Os gráficos com as séries de razão de mistura do vapor de água para os cincos ambientes estão reportados na Figura 26.
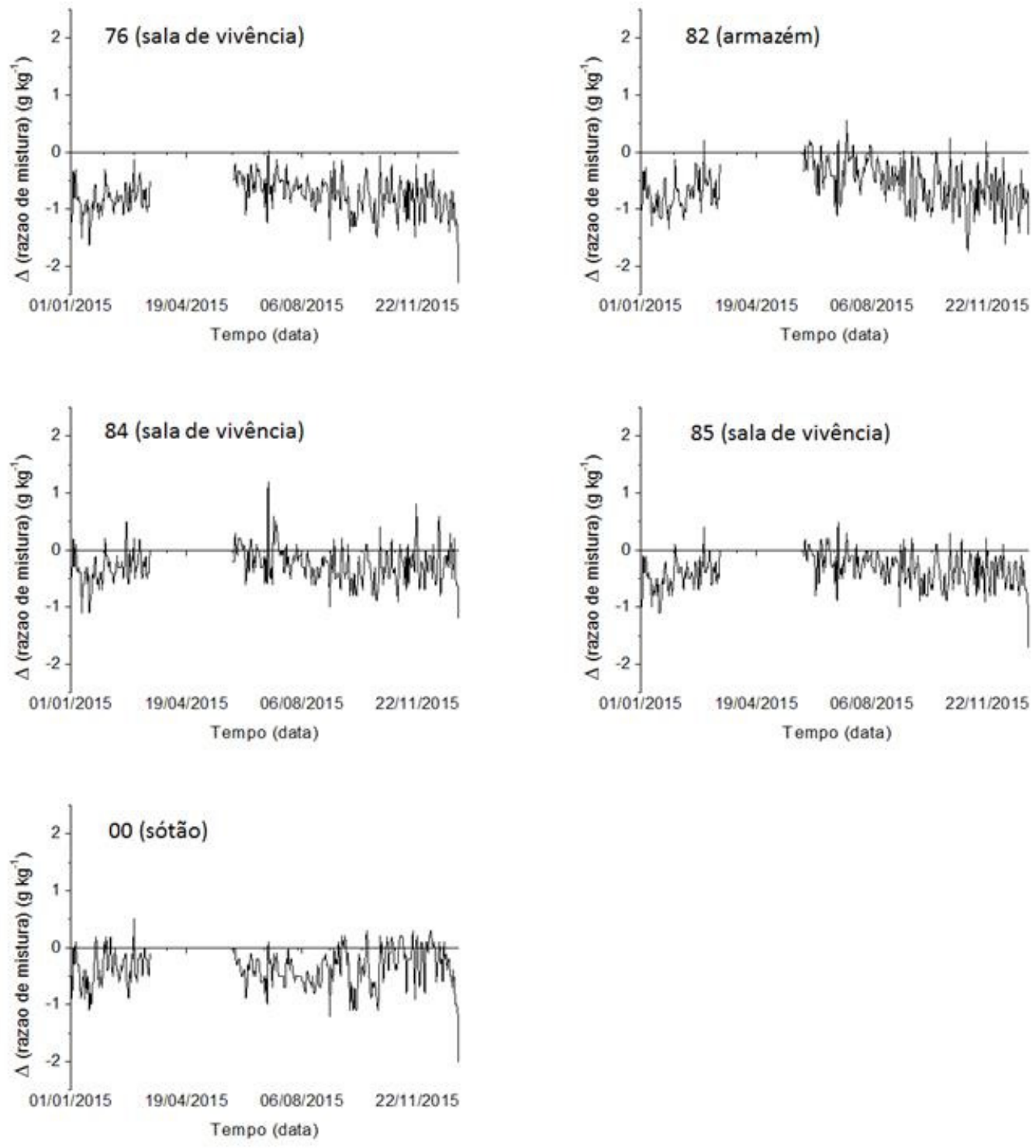

Figura 26. Séries temporais das diferenças entre a razão de mistura do vapor $\left(\mathrm{g} \mathrm{kg}^{-1}\right)$ nos locais indoor e no ambiente outdoor na Fazenda São Miguel no período de 1/1/2015 a 31/12/2015. 
Tabela 11. Razão de mistura do vapor de água $\left(\mathrm{g} \mathrm{kg}^{-1}\right)$ nos locais indoor da São Miguel Grande. Valor da razão de mistura média anual no ambiente exterior: $13,6 \mathrm{~g} \mathrm{~kg}^{-1}$.

\begin{tabular}{|c|c|c|c|c|c|}
\hline & 76 (Sala vivência) & 82 (Armazém) & 84 (Sala vivência) & 85 (Sala vivência) & 00 (Sótão) \\
$\begin{array}{c}\text { Valores médios anuais } \\
\text { em } 2015(\%)\end{array}$ & 12,8 & 13,0 & 13,3 & 13,2 & 13,2 \\
\hline $\begin{array}{c}\text { Médias das diferenças } \\
\text { indoor/outdoor (\%) }\end{array}$ & $-0,8$ & $-0,6$ & $-0,3$ & $-0,4$ & $-0,4$ \\
\hline
\end{tabular}

Com relação à temperatura (Tabela 12), em todos os ambientes indoor a temperatura média anual é maior do que a temperatura média outdoor $\left(21,6{ }^{\circ} \mathrm{C}\right.$ em 2015), mas as diferenças são significativamente inferiores que no caso da Fazenda SF monitorada no mesmo período (esse fato possivelmente explica os maiores níveis de umidade relativa).

Sobretudo, destaca-se a maior semelhança em comportamento entre os diversos ambientes da casa em comparação com a outra fazenda. Aparentemente, essa situação decorre de uma maior facilidade de troca térmica demonstrada pelo sótão, conforme curvas do gráfico das variações horárias tanto no verão como no inverno: nelas se percebe o aparecimento de fases negativas nos ciclos referentes ao sótão, o que indica haver momento em que esse espaço apresenta temperatura inferiores às externas (assim como os demais espaços do casarão). Entretanto, numa visão média, o sótão continue mais quente do que a atmosfera outdoor. É interessante, também, salientar o aparecimento de períodos de temperatura média indoor inferior à externa, como é o caso da sala no pavimento de baixo da Fazenda S. Miguel nos dias 1-2, 7 a 20 e 27 a 30 de janeiro 2015. É curioso que, na janela temporal selecionada na Figura 27, nos dias 17, 18 e 19 quando o sótão apresenta picos de temperatura (decorrentes de um real aumento na temperatura externa conforme foi verificado), o armazém da casa (piso inferior) apresenta as maiores diferenças negativas com relação à temperatura externa, o que aponta para uma significativa resiliência térmica desse ambiente.

Uma interpretação aprofundada das razões das diferenças entre essa e a Fazenda São Francisco não pode, ainda, ser desenvolvida por falta de uma caracterização técnica dos elementos arquitetônicos das mesmas, mas interessa enfatizar a existência de uma gama de condições microclimáticas nos diversos contextos e, portanto, a necessidade de sempre avaliar com cuidado cada situação como sendo individual, mesmo que dentro de um quadro geral do tipo que está sendo descrito. 
Tabela 12. Quadro das condições médias de temperatura nos locais interiores da Fazenda São Miguel

\begin{tabular}{|c|c|c|c|c|c|}
\hline & 76 (Sala vivência) & 82 (Armazém) & 84 (Sala vivência) & 85 (Sala vivência) & 00 (Sótão) \\
\hline $\begin{array}{l}\text { Valores médios anuais } \\
\text { em } 2015 \mathrm{~F}(\mathrm{C})\end{array}$ & 22,8 & 22,5 & 23,2 & 22,5 & 22,7 \\
\hline $\begin{array}{l}\text { Médias das diferenças } \\
\text { indoor/outdoor }\left({ }^{\circ} \mathrm{C}\right)\end{array}$ & $+1,2$ & $+0,9$ & $+1,6$ & $+1,0$ & $+1,1$ \\
\hline $\begin{array}{l}\text { Valores médios em } 2015 \\
\text { (C)): meses de jun-ago }\end{array}$ & 19,9 & 20,4 & 20,5 & 19,5 & 19,4 \\
\hline $\begin{array}{l}\text { Médias das diferenç̧as } \\
\left.\text { indoor/outdoor }{ }^{\circ} \mathrm{C}\right) \text { : } \\
\text { meses de jun-ago }\end{array}$ & $+1,4$ & $+1,8$ & $+1,9$ & $+0,9$ & $+0,9$ \\
\hline $\begin{array}{l}\text { Valores médios em } 2015 \\
\text { (C)): meses de dez-fev }\end{array}$ & 24,9 & 24,1 & 25,3 & 24,8 & 25,1 \\
\hline $\begin{array}{l}\text { Médias das diferenças } \\
\text { indoor/outdoor( } \mathrm{C} \text { C): } \\
\text { meses de dez-fev }\end{array}$ & $+1,1$ & $+0,3$ & $+1,5$ & $+1,0$ & $+1,3$ \\
\hline
\end{tabular}

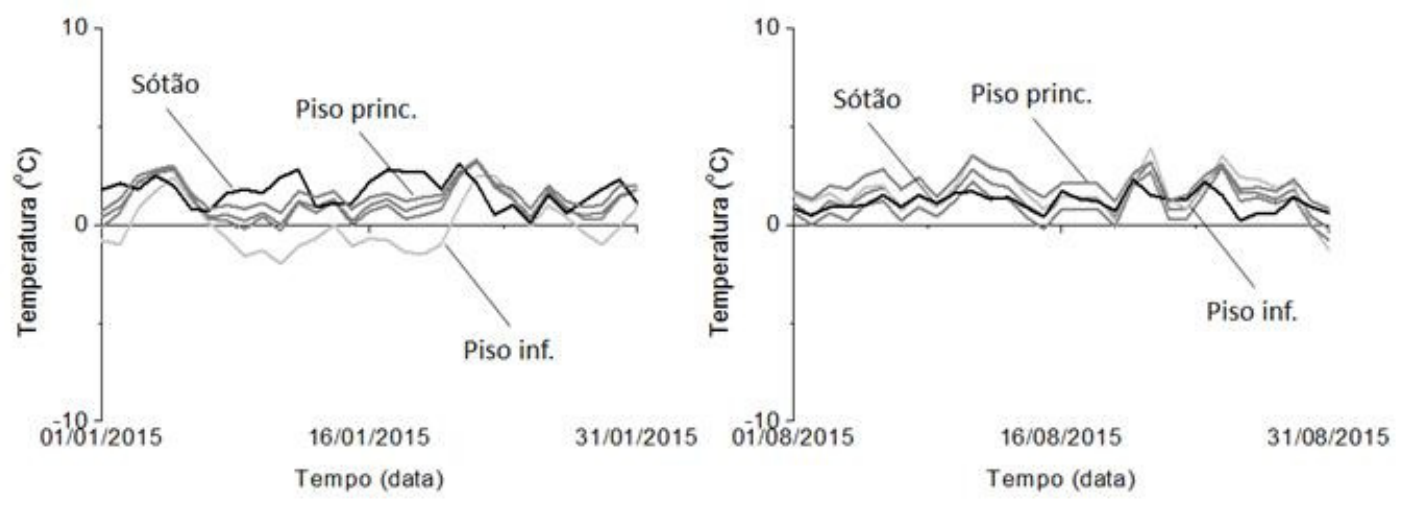

Figura 27. Detalhamento da variação das temperaturas médias diárias medidas em cinco locais do casarão em dois períodos climaticamente distintos: janeiro (ESQ.) e agosto (DIR.) na fazenda São Miguel. Nas plotagem, foram usados valores diferenciais frente às temperaturas médias diárias externas. 

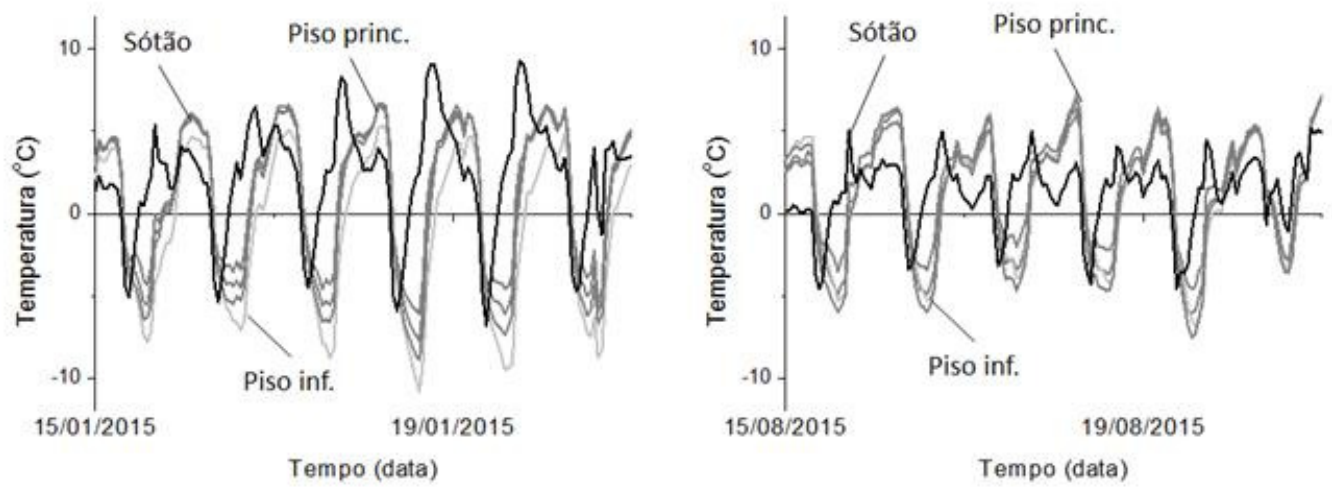

Figura 28. Detalhamento da variação das temperaturas horárias medidas em cinco locais do casarão em dois períodos climaticamente distintos: janeiro (ESQ.) e agosto (DIR.) na fazenda São Miguel. Nas plotagem, foram usados valores diferenciais frente às temperaturas médias diárias externas.

A Fazenda Vargem Grande foi monitorada no período de junho 2013 a maio 2014 e apresenta condições de UR parecidas (em termos de diferenças com o ambiente externo, Tabela 13) com a Fazenda São Miguel: as diferenças da média com relação ao ambiente externo estão compreendidas entre aproximadamente 7 e 10 unidades percentuais. Isso, nos valores absolutos, redundou em níveis médios de UR que atingiram $72 \%$ naquele período, ou seja, condições plenamente favoráveis ao desenvolvimento de agentes de biodeterioração.

Tabela 13. Quadro das condições médias de umidade relativa nos locais interiores da Fazenda Vargem Grande

$$
\text { Nivel principal: sala Nivel inferior: sala de estar Sótão }
$$

Valores médios anuais em 2013/2014 (\%)

Médias das diferenças indoor/outdoor (\%)
72,3

69,7

$-9,8$
71,7

$-7,6$ 

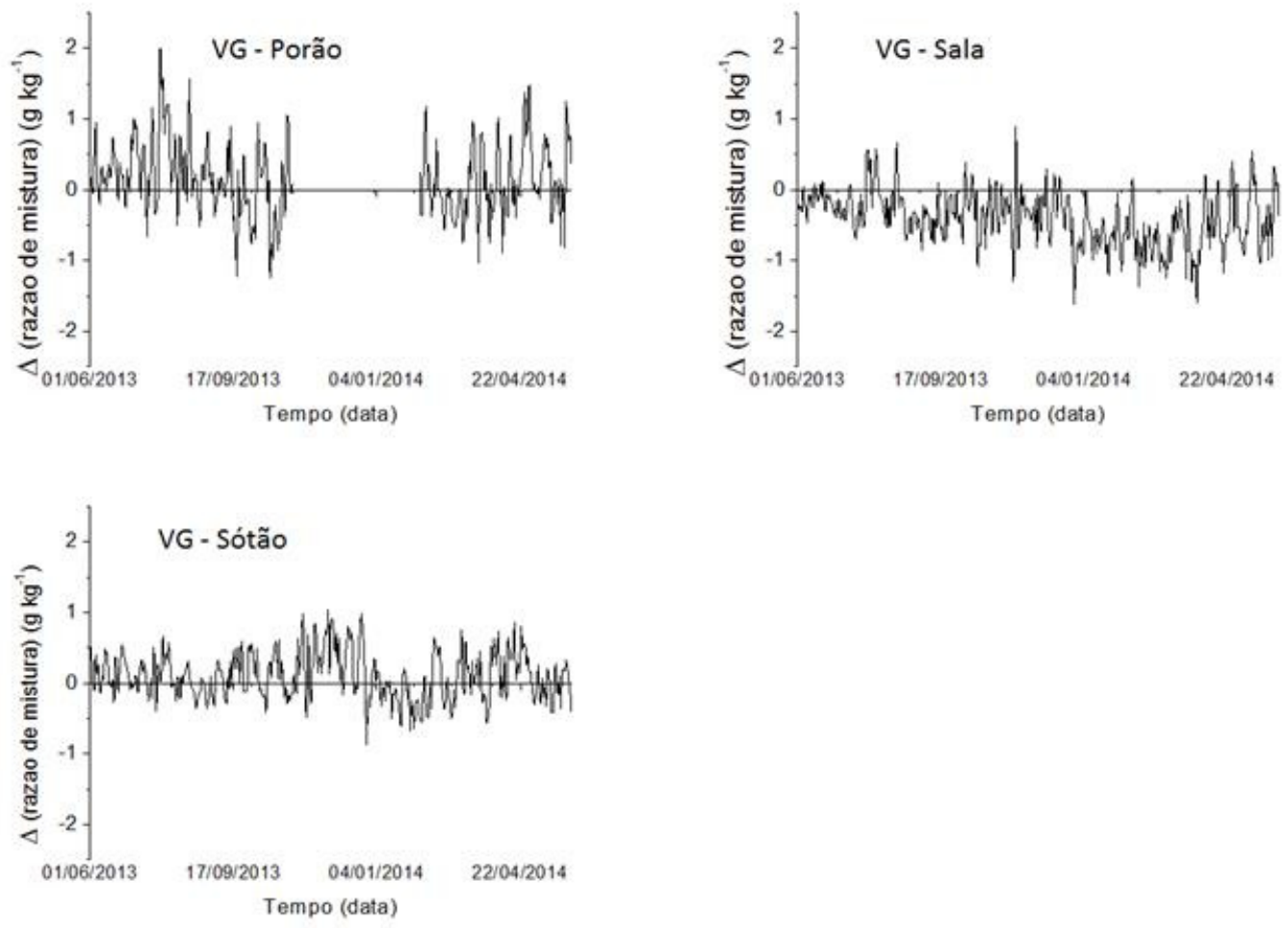

Figura 29. Séries temporais das diferenças entre a razão de mistura do vapor $\left(\mathrm{g} \mathrm{kg}^{-1}\right)$ nos locais indoor e no ambiente outdoor na Fazenda Vargem Grande no período de 1/6/2013 a 31/5/2014.

Tabela 14. Razão de mistura do vapor de água $\left(\mathrm{g} \mathrm{kg}^{-1}\right)$ nos locais indoor da Fazenda Vargem Grande. Valor da razão de mistura média anual no ambiente exterior: $12,6 \mathrm{~g} \mathrm{~kg}^{-1}$.

$$
\text { Nivel principal: sala Nivel inferior: sala de estar Sótão }
$$

Valores médios anuais em 2013/2014 (\%)

Médias das diferenças indoor/outdoor (\%)
12,2

$-0,4$
12,1

0,2
12,7

0,1

No que diz respeito à temperatura (Tabela 14), o quadro, como o da UR, se assemelha ao da Fazenda São Miguel, já que em todos os ambientes indoor a temperatura média anual é maior do que a temperatura média exterior $\left(20,8{ }^{\circ} \mathrm{C}\right.$ no período monitorado), mas com diferenças indoor/outdoor relativamente reduzidas, a dizer, na faixa de 1,0 a $2,3{ }^{\circ} \mathrm{C}$. Cabe lembrar que os dados do ambiente inferior foram afetados pela perda de dados do período de outono e verão, o que prejudica a avaliação na escala anual e no verão.

Contudo, olhando para os valores do inverno e das médias anuais da sala e do sótão, verifica-se que nesse contexto é o piso inferior que se destaca com as 
temperaturas mais altas, muito embora é possível que se os dados de verão estivessem mais completo esse local apresente uma média de $\Delta \mathrm{T}$ um pouco menor, já que os gráficos da Figura 30 indicam que o seu perfil de temperatura no verão acompanha a sala do piso principal. Ou seja, a média está sendo puxada para um valor mais elevado pelo valores do inverno (o "porão" da casa tampona adequadamente as quedas invernais de temperatura). Por contra, diferente da São Miguel, o sótão da VG tende a acumular mais calor com raras incursões em $\Delta \mathrm{T}$ tanto no inverno como no verão.

Tabela 15. Quadro das condições médias de temperatura nos locais interiores da Fazenda Vargem Grande

\begin{tabular}{|c|c|c|c|}
\hline & Nivel principal: sala & Nivel inferior: sala de estar & Sótão \\
\hline $\begin{array}{l}\text { Valores médios anuais em 2013/2014 } \\
\text { (C) }\end{array}$ & 21,8 & $(22,3)$ & 22,7 \\
\hline $\begin{array}{l}\text { Médias das diferenças indoor/outdoor } \\
\text { (C) }\end{array}$ & $+1,0$ & $(+2,3)$ & $+1,9$ \\
\hline $\begin{array}{c}\text { Valores médios em 2013/2014 ( } \\
\text { meses de jun-ago }\end{array}$ & 18,8 & 20,6 & 19,6 \\
\hline $\begin{array}{l}\text { Médias das diferenchas indoor outdoor } \\
\text { ('C): meses de jun-ago }\end{array}$ & $+1,0$ & $+2,8$ & $+1,8$ \\
\hline $\begin{array}{l}\text { Valores médios em 2013/2014 }{ }^{\circ} \mathrm{C} \text { ): } \\
\text { meses de dez-fev }\end{array}$ & 25,1 & $(26,0)$ & 26,4 \\
\hline $\begin{array}{l}\text { Médias das diferenças indoor/outdoor } \\
\text { ('C): meses de dez-fev }\end{array}$ & $+0,9$ & $(+1,2)$ & $+2,2$ \\
\hline
\end{tabular}



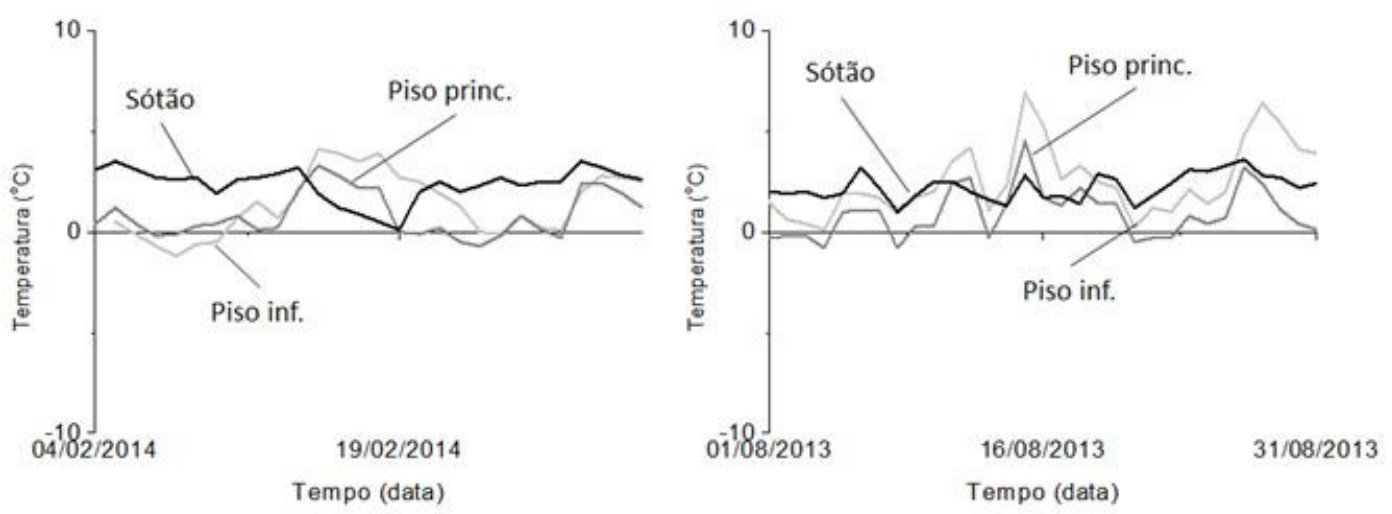

Figura 30. Detalhamento da variação das temperaturas médias diárias medidas em três locais do casarão em dois períodos climaticamente distintos: fevereiro (ESQ.) e agosto (DIR.) na Fazenda Vargem Grande. Nas plotagem, foram usados valores diferenciais frente às temperaturas médias diárias externas.
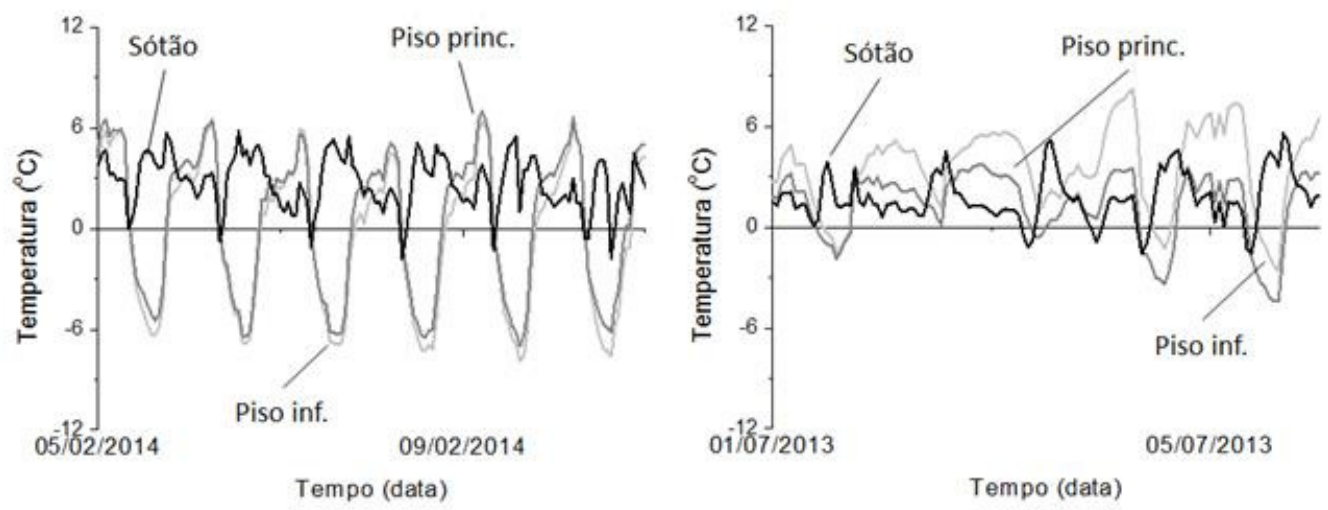

Figura 312. Detalhamento da variação das temperaturas horárias medidas em três locais do casarão em dois períodos climaticamente distintos: janeiro (ESQ.) e agosto (DIR.) na fazenda Vargem Grande. Nas plotagem, foram usados valores diferenciais frente às temperaturas médias diárias externas.

Por fim, as medidas climáticas da Fazenda Catadupa: essas, infelizmente, ficaram prejudicadas, pois os sensores ficaram armazenados no ambiente da sala do nível principal de jun até set, sendo depois instalados nos locais definidos a partir desse momento, conforme detalhado em outra seção. Considerou-se completo somente o conjunto de valores dessa sala, já para as demais se focou a discussão nos dados de verão.

Nessa quarta fazenda, continua-se com condições de umidade relativa médias em níveis de relativo risco. A situação pior é representada pela senzala com UR média 6,2 unidades percentuais abaixo da média externa, diferença que cai para 4,8 se forem 
desconsiderados os dados do período de junho a setembro quando o sensor da senzala, de fato, ficou em ambiente menos úmido (Tabela 16).

Tabela 161. Quadro das condições médias de umidade relativa nos locais interiores da Fazenda Catadupa.

\begin{tabular}{|c|c|cc|}
\hline & Nivel principal: sala & Nivel inferior: senzala & Sotão \\
\hline $\begin{array}{c}\text { Valores médios anuais em } \\
2013 / 2014(\%)\end{array}$ & 67,8 & $(73,1)$ & 69,7 \\
\hline $\begin{array}{c}\text { Médias das diferenças } \\
\text { indoor/outdoor }(\%)\end{array}$ & $-11,5$ & $(-6,2)$ & $-9,6$ \\
\hline
\end{tabular}
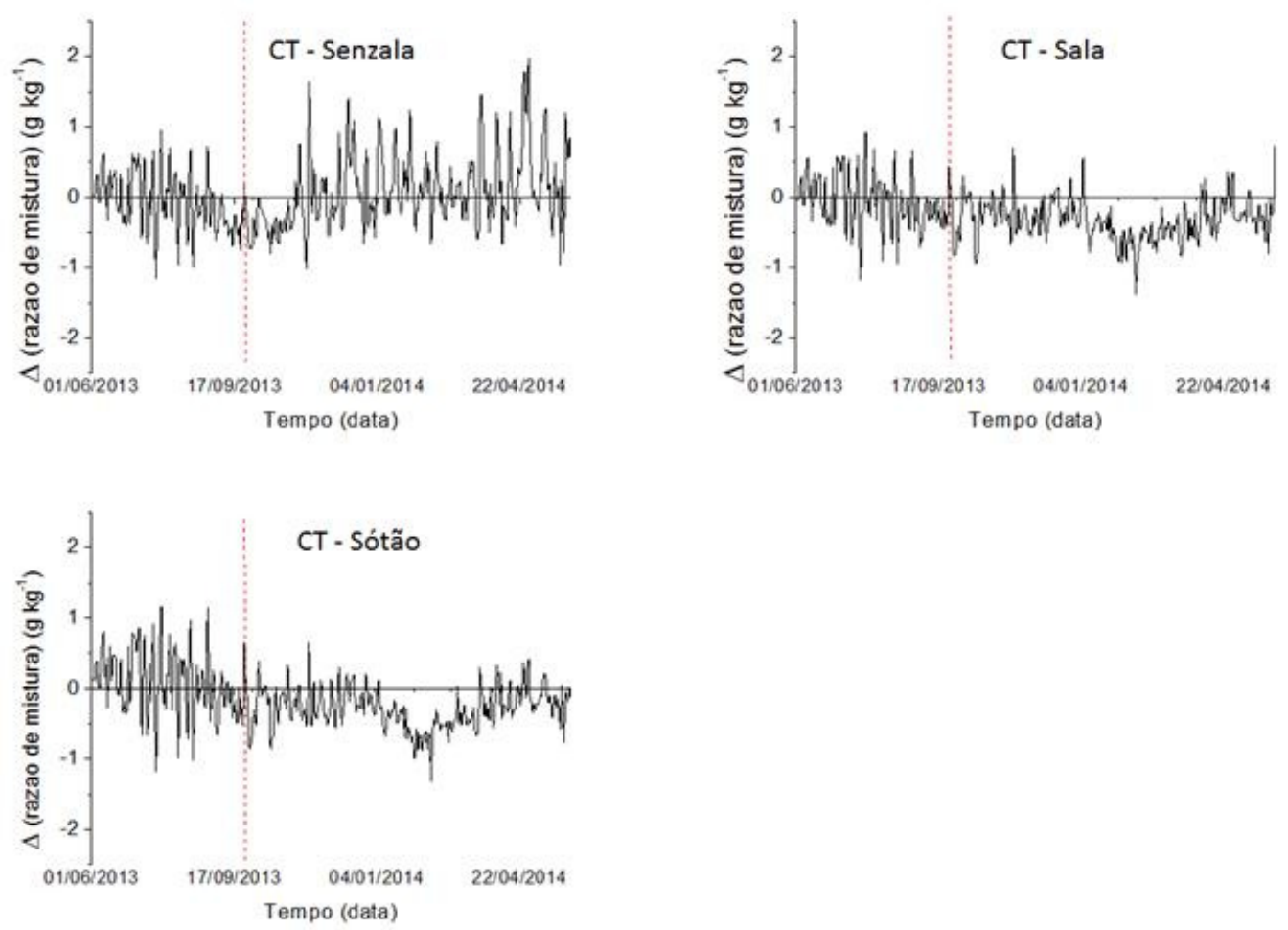

Figura 32. Séries temporais das diferenças entre a razão de mistura do vapor $\left(\mathrm{g} \mathrm{kg}^{-1}\right)$ nos locais indoor e no ambiente outdoor na Fazenda Catadupa no período de 1/6/2013 a 31/5/2014. 
Tabela 17. Razão de mistura do vapor de água $\left(\mathrm{g} \mathrm{kg}^{-1}\right)$ nos locais indoor da Fazenda Catadupa. Valor da razão de mistura média anual no ambiente exterior: $12,6 \mathrm{~g} \mathrm{~kg}^{-1}$.

\begin{tabular}{|c|c|cc|}
\hline & Nivel principal sala & Nivel inferior: senzala & Sotão \\
\hline $\begin{array}{c}\text { Valores médios anuais em } \\
\text { 2013/2014 (\%) }\end{array}$ & 12,4 & 12,7 & 12,5 \\
\hline $\begin{array}{c}\text { Médias das diferenças } \\
\text { indoor/outdoor }(\%)\end{array}$ & $-0,2$ & $(0,0)$ & $(-0,2)$ \\
\hline
\end{tabular}

Os dados da temperatura de verão dessa fazenda (Tabela 18 e Figuras 33-34) indicam a escassa tendência ao acúmulo e dispersão de calor por parte da senzala, em linha com os resultados dos ambientes inferiores da Fazenda São Francisco e São Miguel, mas de forma mais acentuada. Esse ambiente é o que mais se configura como um porão, com as menores flutuações de temperatura e a maior umidade.

O sótão mostra um comportamento anómalo frente mesmo local nas demais fazendas, mas isso se explica pelo fato desse casarão ter o forro da maioria dos quartos desmontado, eliminando o fator de isolamento e proporcionando uma maior circulação de ar e de calor. Essa mesma característica pode ser responsável pelo regime térmico da área de vivência principal, que entre todas as fazendas é a que apresenta o maior acúmulo de calor com relação ao ambiente externo. 
Tabela 18. Quadro das condições médias de temperatura nos locais interiores da Fazenda Catadupa.

\begin{tabular}{|c|c|c|c|}
\hline & Nivel principal: sala & Nivel inferior: senzala & Sotão \\
\hline $\begin{array}{l}\text { Valores médios anuais em 2013/2014 } \\
\text { (C) }\end{array}$ & 19,1 & $(22,2)$ & $(22,8)$ \\
\hline $\begin{array}{l}\text { Médias das diferenças indoor/outdoor } \\
\qquad(\mathrm{C})\end{array}$ & $+2,3$ & $(+1,3)$ & $(+1,9)$ \\
\hline $\begin{array}{c}\text { Valores médios em 2013/2014 (C): } \\
\text { meses de jun-ago }\end{array}$ & 18,6 & $(18,6)$ & $(18,9)$ \\
\hline $\begin{array}{l}\text { Médias das diferenças indoor/outdoor } \\
\text { ('C): meses de jun-ago }\end{array}$ & $+0,1$ & $(+0,2)$ & $(+0,4)$ \\
\hline $\begin{array}{l}\text { Valores médios em 2013/2014 ( } \mathrm{C} \text { ): } \\
\text { meses de dez-fev }\end{array}$ & 27,3 & 24,6 & 26,1 \\
\hline $\begin{array}{l}\text { Médias das diferenças indoor/outdoor } \\
\text { (C)): meses de dez-fev }\end{array}$ & $+3,1$ & $+0,5$ & $+1,9$ \\
\hline
\end{tabular}

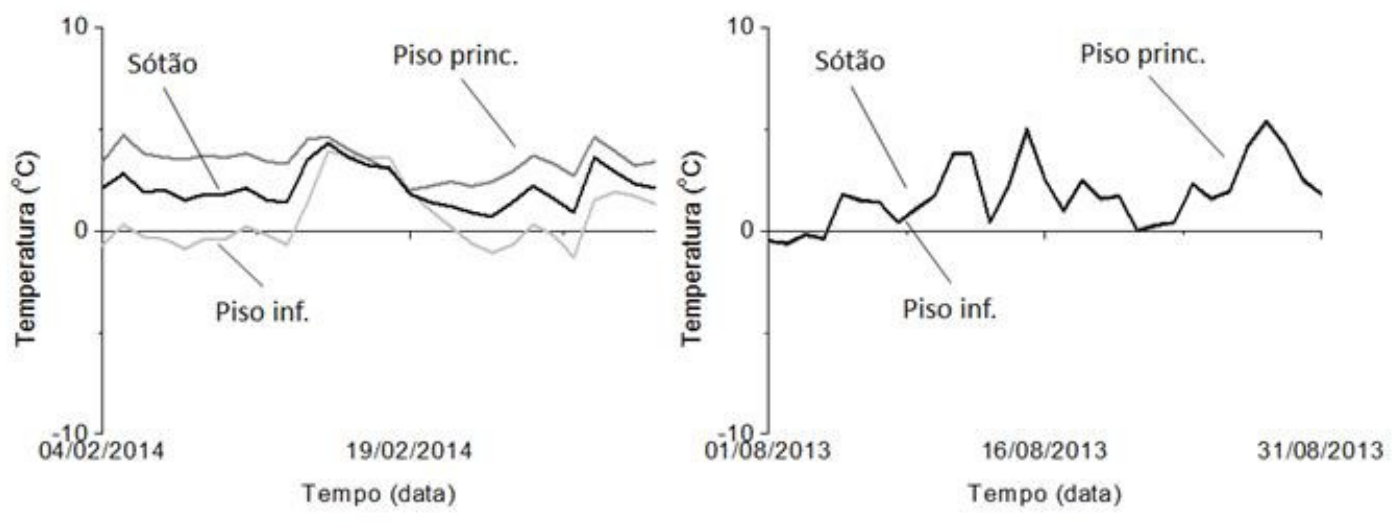

Figura 33. Detalhamento da variação das temperaturas médias diárias medidas em três locais do casarão em dois períodos climaticamente distintos: fevereiro (ESQ.) e agosto (DIR.) na Fazenda Catadupa. Nas plotagem, foram usados valores diferenciais frente às temperaturas médias diárias externas. 

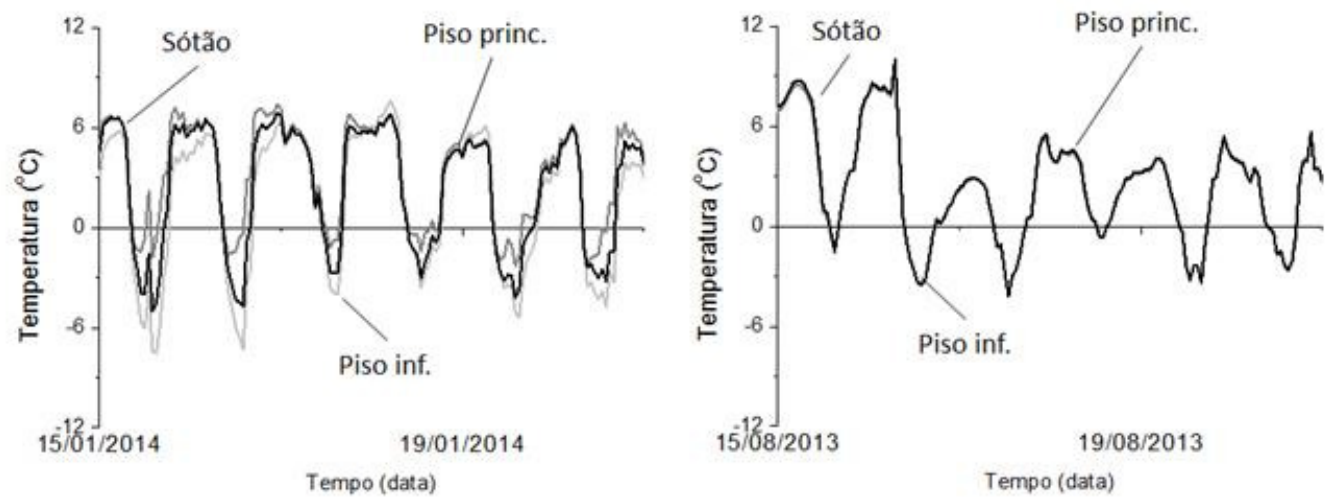

Figura 34. Detalhamento da variação das temperaturas horárias medidas em três locais do casarão em dois períodos climaticamente distintos: janeiro (ESQ.) e agosto (DIR.) na fazenda Catadupa. Nas plotagem, foram usados valores diferenciais frente às temperaturas médias diárias externas.

Considerando-se os dados de todas as fazendas é interessantes destacar alguns pontos. Pode-se notar que não existe uma uniformidade nas condições microclimáticas, o que ressalta a importância de se fazer as coletas de dados microclimáticos em diversas edificações e em diversos pontos numa mesma edificação para se obter uma caracterização micro climática mais representativa.

No mesmo sentido, observou-se o microclima das edificações é sempre consideravelmente diverso do clima externo. Umidade relativa indoor mais baixa, mas ainda dentro dos valores de risco definidos pela literatura e a temperatura, tipicamente de 1 a 3 graus mais elevada (na média anual) nos locais internos com relação aos externos (essa diferença possivelmente tenha um papel na manutenção da UR de 6 a 15 unidades percentuais abaixo da externa e, portanto, tem um papel positivo ainda que colabore no crescimento de fungos). Os sótãos tendem a ser mais quentes (raramente caindo abaixo da $\mathrm{T}$ externa) e os pavimentos inferiores os que melhor tamponam as variações de temperatura, ainda que apresentando valores médios de $\mathrm{T}$ maiores que a $\mathrm{T}$ externa. Observações essas que também evidencia a importância da caracterização dos microclimas, pois os valores internos indoor de UR e temperatura são mais para analise da atividade dos micro-organismos lignocelulolíticos do que os valores outdoor. 


\subsection{Análise da resposta microbiológica a diferentes temperaturas}

Nos gráficos das Figuras 35-38 observa-se que, de forma geral, as temperaturas futuras propiciaram crescimento mais rápido das cepas em comparação as temperaturas presentes. Porém, as diferenças de crescimento foram muito mais significativas nas simulações de inverno do que nas simulações de verão. Das 10 cepas testadas, nove obtiveram crescimento mais rápido a $24^{\circ} \mathrm{C}$ (previsão da temperatura média futura de inverno) do que a 20 (temperatura média presente de inverno).

Na Figura 35 (C) deve-se destacar que os experimentos com a cepa 47 não indicaram diferença relevante entre o crescimento a $26{ }^{\circ} \mathrm{C}$ (temperatura presente de verão) e $29^{\circ} \mathrm{C}$ (temperatura futura de verão). Na Figura 37 (C), a situação se repete com a cepa 62.

A cepa 38 foi a única que cresceu mais rápido nas temperaturas mais baixas, tanto nos testes de inverno quanto de verão, como pode ser observado na Figura 38 (A) e (B). No caso da simulação de verão, o crescimento é, inicialmente, maior à temperatura de $29^{\circ} \mathrm{C}$, porém, após o terceiro dia, o crescimento sofre brusca desaceleração. 

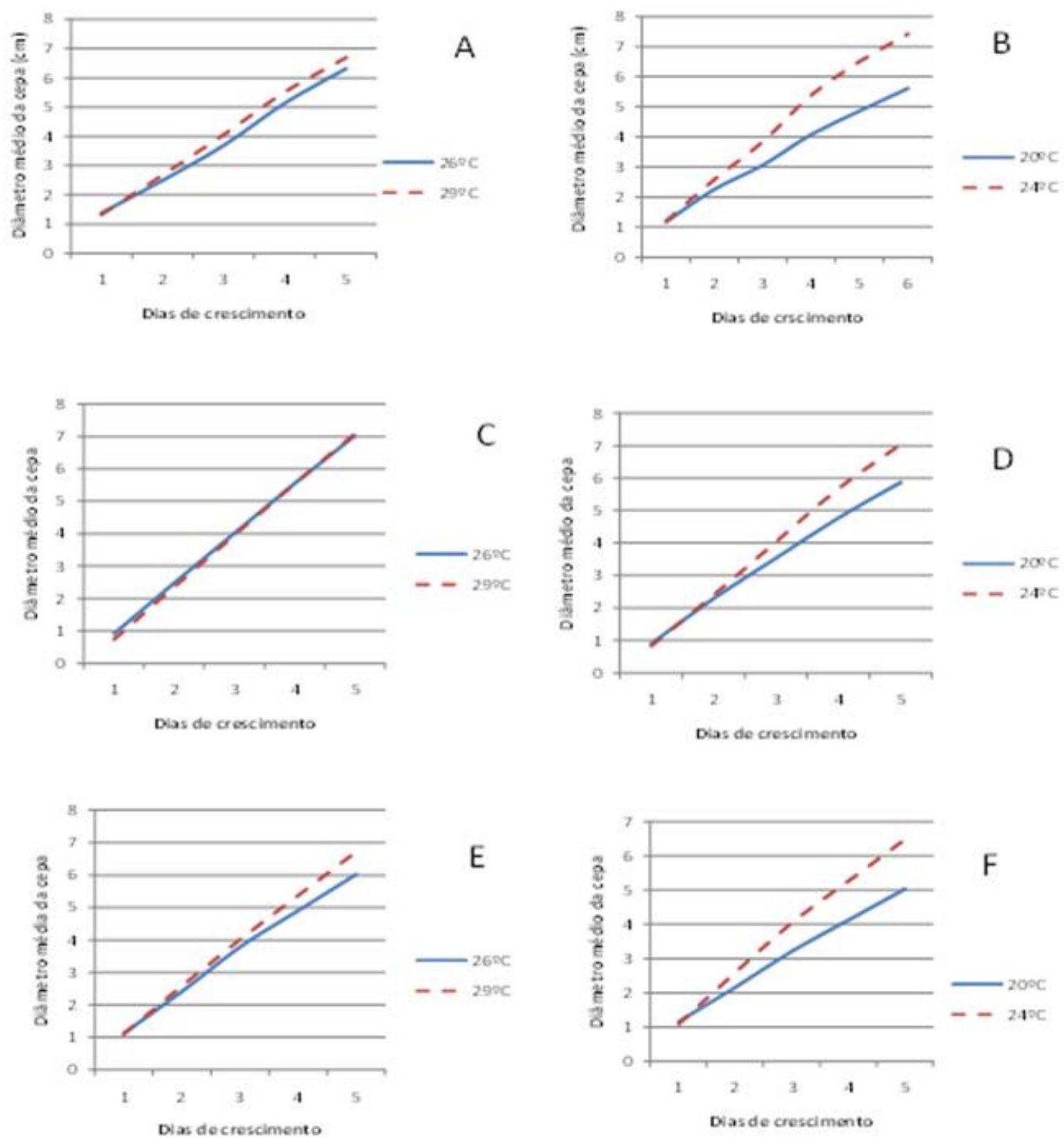

Figura 35. Crescimento das cepas em temperaturas médias de inverno e verão, presentes e previstas para o final do século XXI. (A) cepa 37 - crescimento a temperaturas médias de verão presente $\left(26^{\circ} \mathrm{C}\right)$ e futura $\left(29^{\circ} \mathrm{C}\right)$; (B) cepa 37 - crescimento a temperaturas médias de inverno presente $\left(20^{\circ} \mathrm{C}\right)$ e futura $\left(24^{\circ} \mathrm{C}\right)$; (C) cepa 47 - crescimento a temperaturas médias de verão presente e futura; (D) cepa 47-crescimento a temperaturas médias de inverno presente e futura; (E) cepa 12, crescimento a temperaturas médias de verão presente e futura; $(\mathrm{F})$ cepa 12 crescimento a temperaturas médias de inverno presente e futura. 

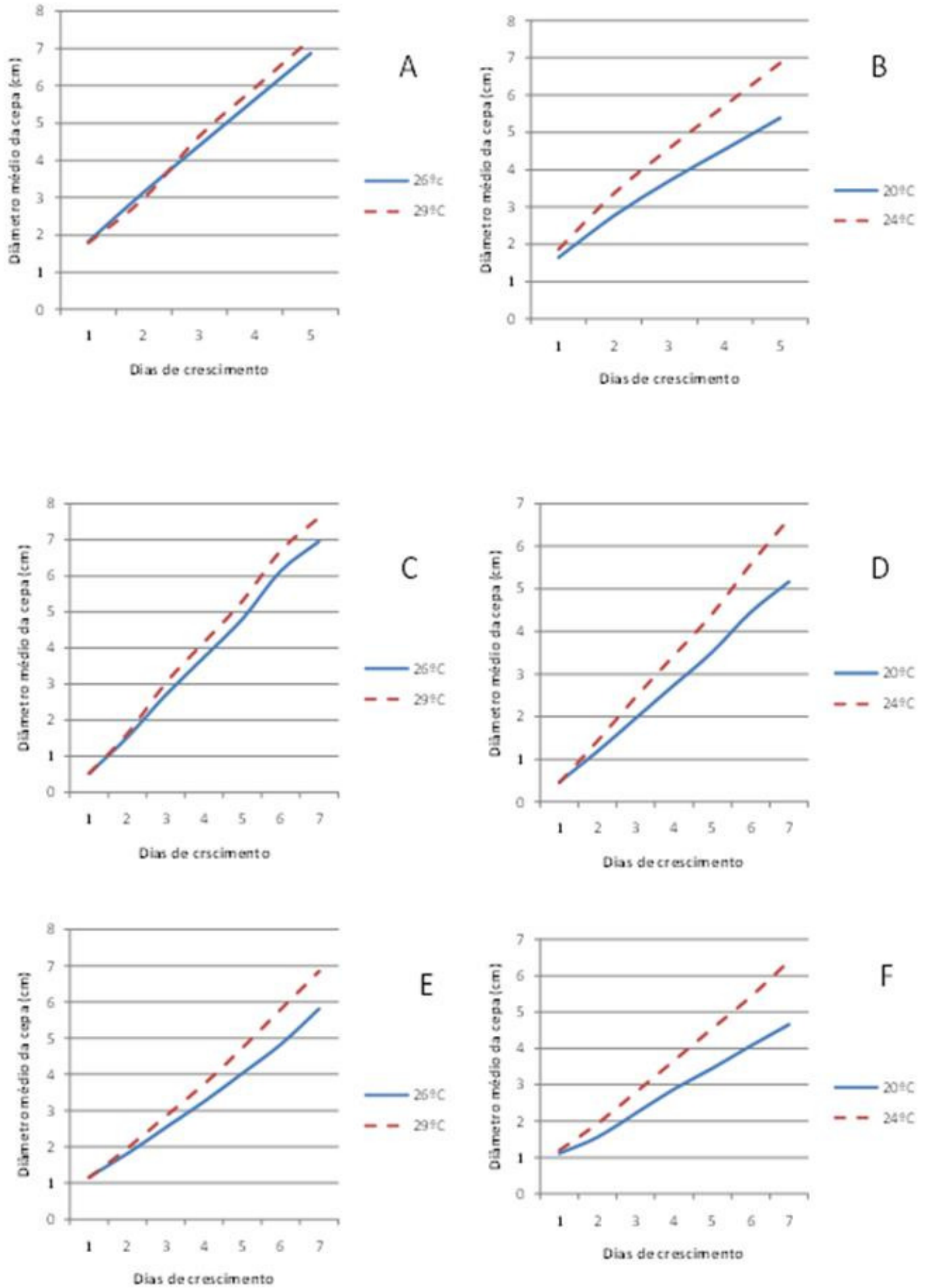

Figura 36. Crescimento das cepas em temperaturas médias de inverno e verão, presentes e previstas para o final do século XXI. (A) cepa 19 - crescimento a temperaturas médias de verão presente $\left(26^{\circ} \mathrm{C}\right)$ e futura $\left(29^{\circ} \mathrm{C}\right)$; (B) cepa 19 - crescimento a temperaturas médias de inverno presente $\left(20^{\circ} \mathrm{C}\right)$ e futura $\left(24^{\circ} \mathrm{C}\right) ;(\mathrm{C})$ cepa 50 - crescimento a temperaturas médias de verão presente e futura; (D) cepa 50-crescimento a temperaturas médias de inverno presente e futura; (E) cepa 64, crescimento a temperaturas médias de verão presente e futura; (F) cepa 64 crescimento a temperaturas médias de inverno presente e futura. 

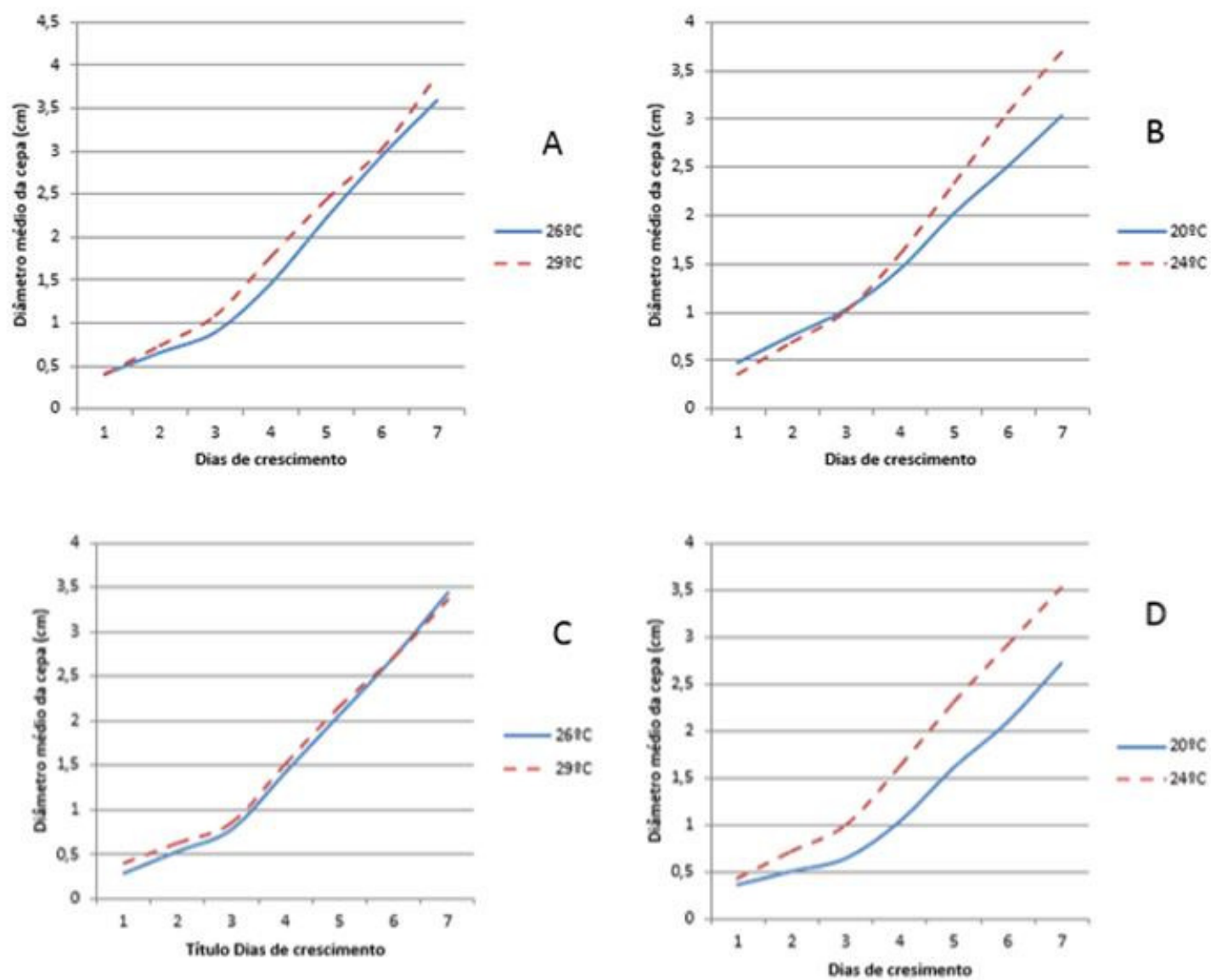

Figura 37. Crescimento das cepas em temperaturas médias de inverno e verão, presentes e previstas para o final do século XXI. (A) cepa 63 - crescimento a temperaturas médias de verão presente $\left(26^{\circ} \mathrm{C}\right)$ e futura $\left(29^{\circ} \mathrm{C}\right)$; (B) cepa 63 - crescimento a temperaturas médias de inverno presente $\left(20^{\circ} \mathrm{C}\right)$ e futura $\left(24^{\circ} \mathrm{C}\right)$; (C) cepa 62 - crescimento a temperaturas médias de verão presente e futura; (D) cepa 62-crescimento a temperaturas médias de inverno presente e futura. 

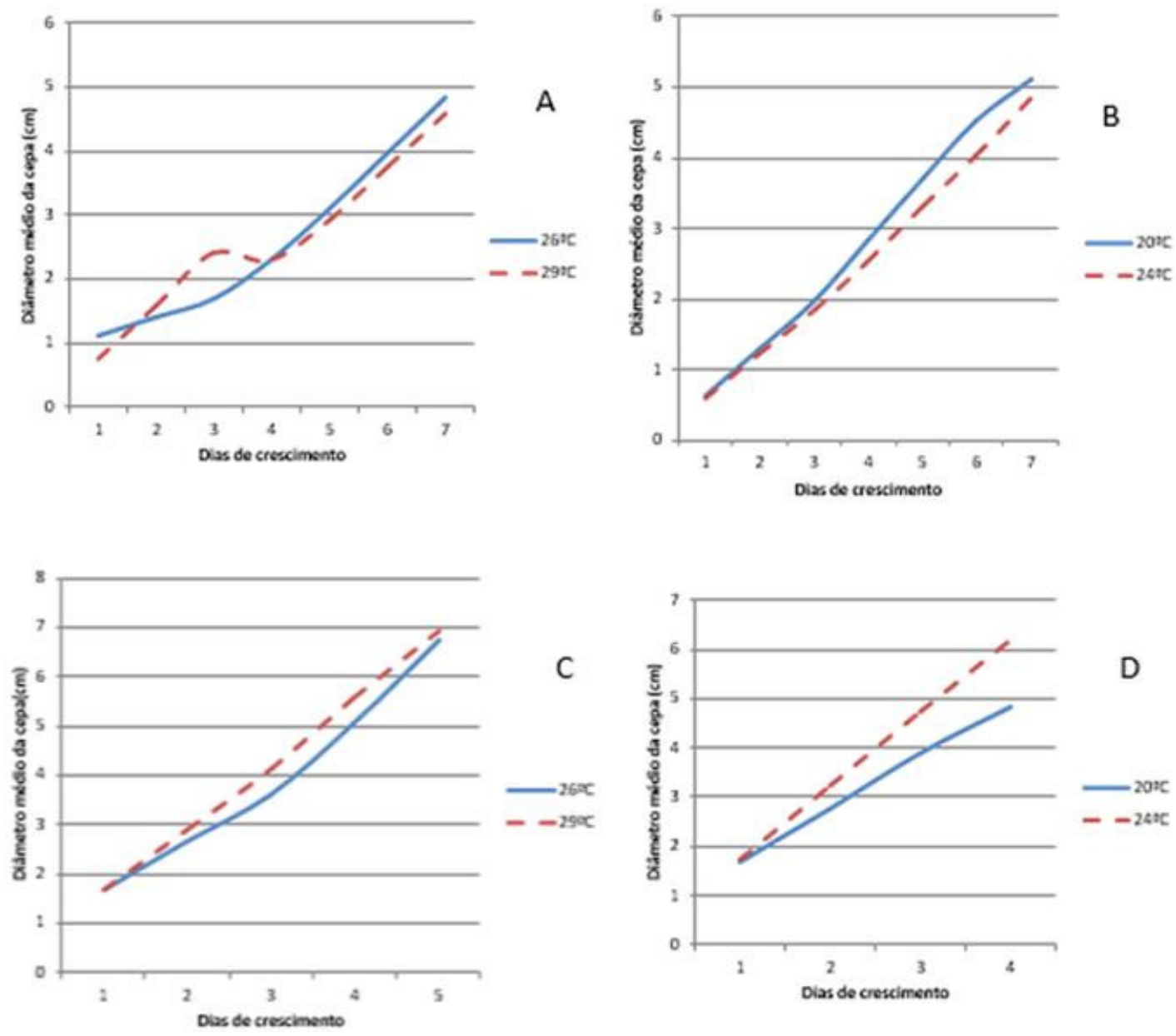

Figura 38. Crescimento das cepas em temperaturas médias de inverno e verão, presentes e previstas para o final do século XXI. (A) cepa 38 - crescimento a temperaturas médias de verão presente $\left(26^{\circ} \mathrm{C}\right)$ e futura $\left(29^{\circ} \mathrm{C}\right)$; (B) cepa 38 - crescimento a temperaturas médias de inverno presente $\left(20^{\circ} \mathrm{C}\right)$ e futura $\left(24^{\circ} \mathrm{C}\right)$; (C) cepa 41 - crescimento a temperaturas médias de verão presente e futura; (D) cepa 41-crescimento a temperaturas médias de inverno presente e futura.

Na Figura 39 verificam-se as curvas de crescimento de todas as cepas para cada temperatura utilizada no experimento. Observa-se que dois grupos bem distintos de curvas. O primeiro grupo, formado pelas curvas de crescimento nas temperaturas 24,26 e $29{ }^{\circ} \mathrm{C}$, tem uma taxa de crescimento consideravelmente maior em comparação ao segundo grupo formado apenas pela curva de crescimento a $20^{\circ} \mathrm{C}$. Pode-se notar que o primeiro grupo os diâmetros médios das cepas chegam ao quarto dia de crescimento com valores próximos a 4 centímetros enquanto no segundo grupo o diâmetro alcançado não atinge os 3,5 centímetros. 


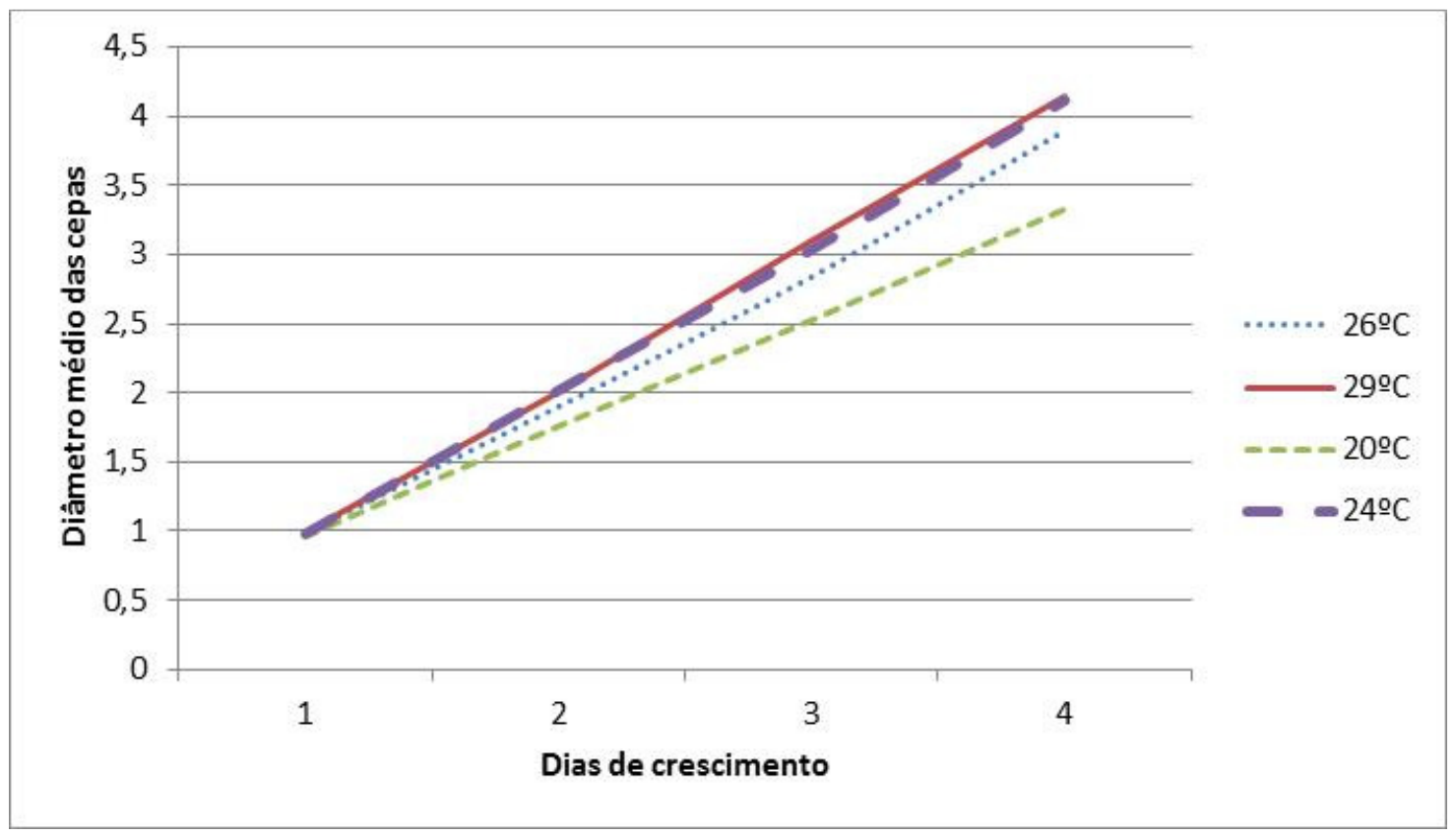

Figura 39. Crescimento do valor médio dos diâmetros das 10 cepas.

A Tabela 19 exibe as taxas de crescimento médio diário de cada cepa nas quatro diferentes temperaturas. As taxas de crescimento acima de $24{ }^{\circ} \mathrm{C}$ são muito semelhantes entre si e muito superiores as taxas de crescimento à $20^{\circ} \mathrm{C}$. Portanto, pode-se dizer que a variação da temperatura média entre $24^{\circ} \mathrm{C}$ e $29^{\circ} \mathrm{C}$ é praticamente irrelevante para o a velocidade de crescimento das cepas. Porém, a variação de temperatura de $20{ }^{\circ} \mathrm{C}$ para $24{ }^{\circ} \mathrm{C}$ proporciona um aumento de $30 \%$ na taxa de crescimento.

Essa avaliação indica que provavelmente a faixa de temperatura de 24 a $29{ }^{\circ} \mathrm{C}$ esteja dentro da faixa ótima de temperatura para a maioria das cepas do estudo. Portanto, o aumento da temperatura das edificações previsto para o verão provavelmente não causara aumento nas atividades dos micro-organismos.

Por outro lado a variação prevista para o inverno é potencialmente impactante. A variação de 20 para $24^{\circ} \mathrm{C}$ insere a temperatura média da estação na suposta faixa ótima de crescimento. Ou seja, atualmente, o inverno é um período do ano em que os fungos tem sua atividade metabólica significativamente desacelerada. A expectativa é, portanto, de que esse período de desaceleração deixe de existir.

A Figura 40 compara a taxas médias de crescimento (média de todas as cepas) para cada temperatura. É visível a distinção entre o crescimento com temperatura acima de $24{ }^{\circ} \mathrm{C}$ e o crescimento a $20^{\circ} \mathrm{C}$.

Tabela 19. Crescimento médio do diâmetro das cepas $(\mathrm{cm} / \mathrm{dia})$ em diferentes temperaturas. A 
última linha traz o crescimento médio de todas as cepas.

\begin{tabular}{|c|c|c|c|c|}
\hline Cepas & 269C & 299C & 20.C & 249-C \\
\hline 37 & 1,24 & 1,34 & 0,89 & 1,24 \\
\hline 47 & 1,53 & 1,58 & 1,25 & 1,55 \\
\hline 12 & 1,22 & 1,40 & 0,97 & 1,35 \\
\hline 19 & 1,26 & 1,37 & 0,93 & 1,25 \\
\hline 50 & 1,03 & 1,18 & 0,78 & 1,03 \\
\hline 64 & 0,78 & 0,95 & 0,59 & 0,87 \\
\hline 63 & 0,53 & 0,58 & 0,43 & 0,56 \\
\hline 62 & 0,48 & 0,49 & 0,39 & 0,51 \\
\hline 38 & 0,63 & 0,64 & 0,75 & 0,71 \\
\hline 41 & 1,27 & 1,31 & 1,16 & 1,48 \\
\hline Média das cepas & 0,99 & 1,08 & 0,81 & 1,06 \\
\hline
\end{tabular}

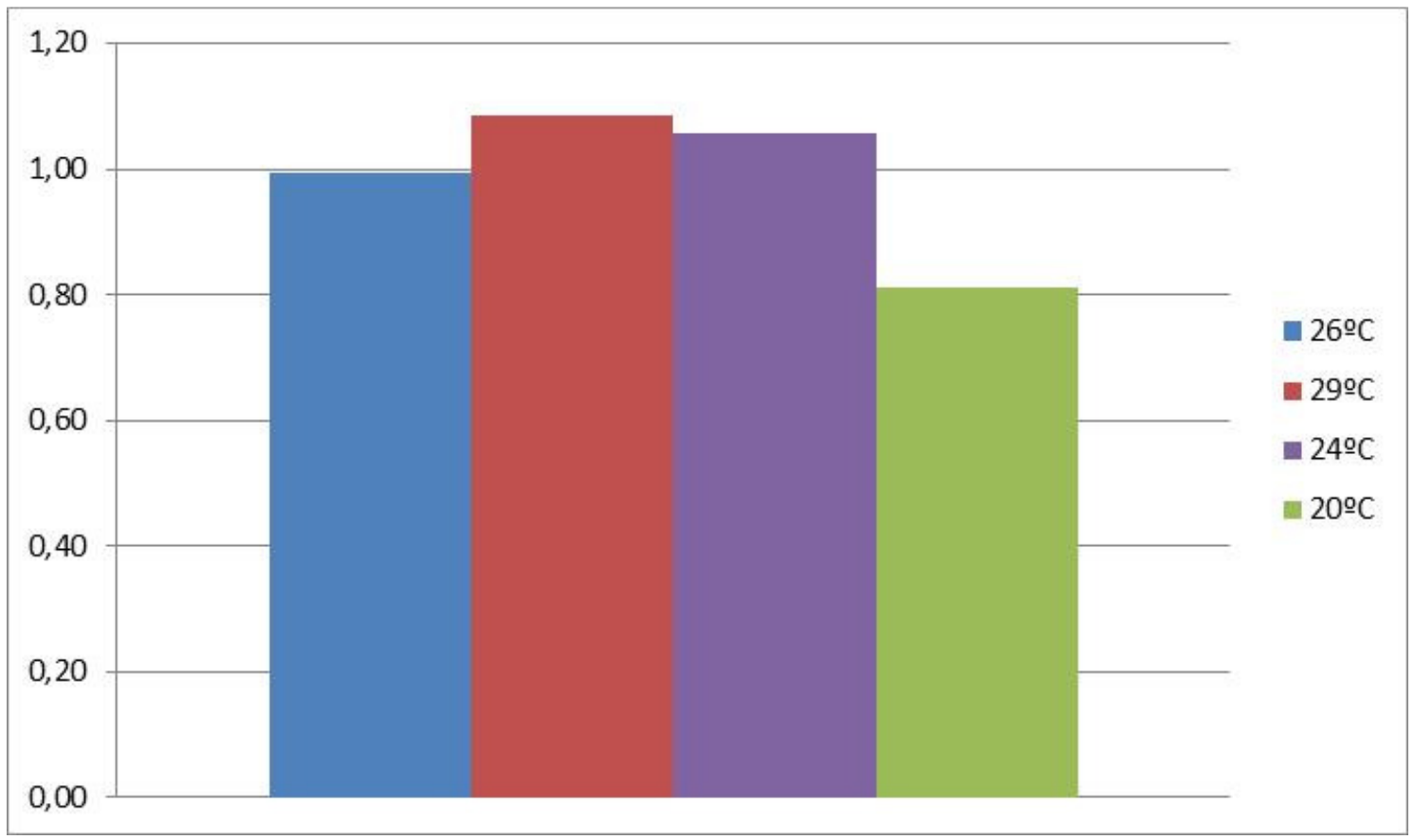

Figura 40. Taxa média de crescimento dos fungos (cm/dia) 


\section{CONCLUSÃO}

O presente trabalho, desenvolvido no âmbito do programa de pós-graduação em Mudança Social e Participação Política, surgiu da preocupação fundamental com a preservação do patrimônio cultural material enxergada como um caminho essencial nos complexo processo de desenvolvimento local em regiões que, como é o caso dos municípios compreendidos no chamado Vale Histórico Paulista, apresentam um problema crônico de depressão econômica e que enfrentam conflitos sociais em boa parte herdados de seu passado de gloria (a riqueza trazida pelo café no século XIX) e de infâmia (a exploração e mão de obra escrava).

A premissa do projeto consistia no pressuposto de que a conservação desse patrimônio, além de envolver ações na esfera política e administrativa, perpassa necessariamente por: i) a ampliação constante dos conhecimentos científicos sobre os fatores que causam o progressivo desgaste dos materiais, sobre os agentes e os mecanismos envolvidos e os fatores que atuam nesses processos, no sentido de acelerálos ou inibi-los; ii) o desenvolvimento de procedimentos e metodologias para tratar as questões praticamente, por meio de diagnósticos direcionados a objetos de estudo específicos; e iii) a formação de profissionais capacitados a abordar tais estudos, eventualmente articulando a ação de diversos profissionais especializados, e a compreender os problemas numa perspectiva multidisciplinar.

Nesse quadro, o trabalho quis propor e ensaiar uma forma para abordar a questão da biodeterioração de materiais de madeiras por parte de fungos numa região escolhida por apresentar ao mesmo tempo um problema expressivo de carência no processo de desenvolvimento local e um riquíssimo patrimônio arquitetônico, em parte ainda preservado em sua originalidade. A pesquisa focou, em particular, na relação entre os agentes de biodeterioração e o clima local, realizando uma incursão na problemática das possíveis alterações climáticas para os próximos cem anos.

Os levantamentos de dados primários e secundários permitiram destacar que não somente o clima da região apresenta todas as características para favorecer o crescimento dos fungos e, portanto, a biodeterioração dos materiais, mas também que os microclimas indoor não proporcionam uma amenização de tal risco. Isso foi mostrado pelo monitoramento dos níveis de umidade relativa (sempre mediamente acima de $60 \%$ e, com frequência, próximos ou até superiores ao patamar crítico de $70 \%$ ) e de 
temperatura: em todos os locais monitorados a temperatura interior média é superior à temperatura exterior, seja na escala anual, seja nas escalas sazonais (inverno e verão), com diferenças de até $3,0{ }^{\circ} \mathrm{C}$ (escala anual) ou $4,2{ }^{\circ} \mathrm{C}$ (escala sazonal, verão). A esse cenário é preciso sobrepor o provável aumento de 3 a $4{ }^{\circ} \mathrm{C}$ calculado mediante a aplicação de modelos numéricos de simulação do clima para o ano de 2100 . No caso da umidade relativa, os dados de literatura não indicam uma taxa muito significativa de acréscimo, ainda que os dois modelos empregados mostrem de um modo geral um aumento das precipitações (com diferenças marcantes nas diferentes estações do ano). Esse último fato precisa ser levado em consideração como elemento de incremento na vulnerabilidade geral das edificações históricas.

O trabalho mostrou, outrossim, a resposta de um grupo selecionado de fungos ao estímulo associado com a temperatura do ar por meio de simulações em câmaras climáticas. Os ensaios foram realizados a partir de espécies escolhidas dentre um banco de 34 fungos não endófitos montado a partir de coletas diretas na região de estudo e de estruturas visivelmente afetadas por processos de biodeterioração, em sua grande maioria apresentando características bioquímicas favoráveis à degradação da madeira.

Os ensaios indicaram que existem diferenças nas taxas de crescimento dos fungos em função da temperatura. As diferenças mais evidentes aparecem na passagem de temperaturas na faixa de $20{ }^{\circ} \mathrm{C}$ para valores maiores $\left(24,26\right.$ e $\left.29{ }^{\circ} \mathrm{C}\right)$, sendo que para os níveis mais elevados (de $24{ }^{\circ} \mathrm{C}$ para cima) esse tipo de comportamento fica menos marcante, ainda que em praticamente todas as comparações entre 26 e $29{ }^{\circ} \mathrm{C}$ os resultados são indicativos novamente de um aumento na taxa de crescimento. Isso induz a pensar que os impactos mais significativos seriam observados no caso de aumentos de temperatura de locais normalmente mais amenos.

Tais observações, por enquanto, ainda não podem ser consideradas conclusivas, seja porque referentes a um espectro relativamente limitado de fungos, seja porque necessitariam de uma confirmação em condições de crescimento mais realistas, por exemplo, diretamente em substratos de madeira.

Uma outra limitação dessa abordagem, salientada em muita literatura sobre biodeterioração por fungos, é o fato das investigações terem focado num conjunto relativamente restrito de espécies de fungos e considerar, de qualquer forma, somente os organismos que puderam ser extraídos das amostras de madeira e viáveis para o crescimento em condições laboratoriais (cultivation-dependant method), que de acordo 
com alguns autores podem representar somente $1 \%$ de toda a população efetivamente presente no substrato. Essa consideração tem levado a abrir cada vez mais espaço para as pesquisas na área de metagenômica que, futuramente, pode representar uma área de expansão importante de pesquisas dessa natureza. 


\section{REFERÊNCIAS}

Ab'SABER, A. N. Os domínio de natureza no Brasil: potencialidades paisagísticas. São Paulo: Ateliê Editorial, 2003.

ALSOPP, D. SEAL, K.J.; GAYLARDE, C.C. Introduction to biodeterioration. $2^{\mathrm{a}}$ ed. Cambridge, Cambridge University Press. 2004, 240 p.

ALOISE, P.; RICCA, M.; LA RUSSA; RUFFOLO, S.A.; BELFIORE, C.M.; PADELETTI, G.; CRISCI, G.M. Diagnostic analysis of stone materials from underwater excavations: the case study of the Roman archaeological site of Baia (Naples, Italy). Applied Physics A, v. 114, p. 655-662, 2014

BENINCASA, V. Fazendas Paulistas: Arquitetura Rural no Ciclo Cafeeiro. 2007, 667 f. Tese (Doutorado-Programa de Pós-Graduação em Arquitetura e Urbanismo) Escola de Engenharia de São Carlos, Universidade de São Paulo, São Carlos, 2007.

BLANCHETTE, R. A. Delignification by wood-decay fungi. Annual Review of Phytopathology, v. 29, p. 381-398, 1991

BLANCHETTE, R. A. A guide to wood deterioration caused by microorganisms and insects. In: DARDES, K. \& ROTNE A. (eds.) The structural conservation of panel paintings. Los Angeles: Getty Conversion Institute, 1998. p. 55-68.

BLANCHETTE, R. A. A review of microbial deterioration found in archaeological wood from different environments. International Biodegradation and Biodeterioration, v. 46, p. 189-203, Abril. 2000.

Disponível em: http://forestpathology.cfans.umn.edu/pdf/IBBreview2000.pdf. Acesso em: 20/3/2013.

BRANCATO, F. P. The Diameter of the Mold Colony as a Reliable Measure of Growth. Mycologia, v. 45, n. 6 pp. 848-864. 
BRAZOLIN, S.; LELIS, A. T. O problema de fungos e insetos xilófagos no museu de artesacra de Salvador-BA. 2002.

Disponível em: www.abracor.com.br/novosite/pdfs/insetos_museu_arte_sacra.pdf.

Acessado em: 20/12/2011

BRIMBLECOMBE, P. e GROSSI, C. M.; HARRIS, I. Climate Change Critical to Cultural Heritage. In: GOMEZ-HERAS e VASQUES-CALVO, eds. Heritage,Weathering and Conservation, London: Taylor \& Francis Group, 2006, págs. 387-393.

BRIMBLECOMBE, P. e GROSSI. Damage to Buildings from Future Climate and Pollution. Association for Preservation Technology International Bulletin, vol. 38, n⿳2/3 (2007), 2007.

Disponível em: http://www.jstor.org/stable/40004714

Acessado em: 10/12/2011

BRIMBLECOMBE, P.; LANKESTER, P. Long-term changes in climate and insect damage in historic houses. Studies in Conservation, v. 0, 2012.

BUCHER, V. V. C.; POINTING, S. B.; HYDE, K. D.; REDDY C. A. Production of wood decay enzymes, loss of mass, and lignin solubilization in wood by diverse tropical freshwater fungi. Microbial Ecology. v. 48, n.3 : p. 331-337. ago. 2004.

Disponível em: link.springer.com/content/pdf/10.1007\%2Fs00248-003-0132-x.pdf Acesso em: 11 Nov. 2012.

CANEVA, G.; NUGARI, M.P.; SALVADORI, O. Biology in conservation of works of art. Roma: ICCROM, 1991. 246 p.

CARRILHO, Marcos. As fazendas de café no Caminho Novo da Piedade. 1994. Dissertação (Mestrado em Arquitetura) - Faculdade de Arquitetura e Urbanismo, Universidade de São Paulo, São Paulo, 1994. 
CARRILlO, M. J. Fazendas de Café Oitocentistas no Vale do Paraíba. Anais do Museu Paulista. São Paulo, vol. 14, n. 1, p. 59-80. jan. - jun. 2006.

CAVICCHIOLI, A; FARIA, D. L. A.; NEVES, C. A. ANTUNES, M. T. Automatic devices for monitoring environmentally induced auto-oxidative degradation of artistic materials in conservation sites, Sensors Actuators B: Chemistry, v. 131, p. 462-469, 2008.

DIAZ-HERRAIZ, M.; JURADO, V. CUEZVA, S.; LAIZ, L.; PALLECCHI, P.; TIANO, P.; SANCHEZ-MORAL, S.; SAIZ-JIMENEZ, C. Deterioration of an Etruscan tomb by bacteria from the order Rhizobiales. Scientific Reports. v. 4, n 3610, pp 1-7, 2014.

DECHAMPS, J.; WRIGHT, J. Patologia forestal del cono sur de America. $1^{\text {a }}$ ed. Buenos Aires: Orientación Gráfica Editora, 1997, 237 p.

DANIEL, G.; NILSSON, T.; Developments in the study of soft rot and bacterial decay. In: BRUCE, A.; PALFREYMAN, J. W. (eds.) Forest Products Biotechnology. London: Francis \& Taylor, 1998. p. 37-62.

D’ELBOUX, R. M. M. Uma promenade nos trópicos: os barões do café sob as palmeiras-imperiais, entre o Rio de Janeiro e São Paulo. Anais do Museu Paulista, São Paulo, v.14, n. 2, p. 193-250, jul.-dez. 2006.

EGGINS, H.O.; OXLEY, T.A. BIODETERIORATION AND BIODEGRADATION. Int. Biodeterioration \& Biodegradation, v. 48, pp 12 -15, 2001 .

ERIKSSON, K.-E.L., BLANCHETTE, R.A., ANDER, P. Microbial and Enzymatic Degradation of Wood and Wood Components. Berlin, Germany: Springer, 1990.

FAZIO, A. T.; CAVICCHIOLI, A.; PENNA, D. S. A.; CHAMBERGO, F.; FARIA, D. L. A. Towards a better comprehension of biodeterioration in earthen architecture: study 
of fungi colonisation on historic wall surfaces in Brazil. J. Cult. Herit., v. 16, p. 934938, 2015.

FAZIO, A.; PAPINUTTI, L; GÓMEZ, B.A.; PARERA, S.D.; ROMERO, A.R.; SIRACUSANO, G.; MAIER, M.S. Fungal deterioration of a Jesuit South American polychrome wood sculpture. International Biodeterioration \& Biodegradation. v. 64, p. 694-701, 2010.

FENGEL, D.; WEGENER, G. Wood Chemistry, Ultrastructure and Reactions. 1 ed. Berlin: Walter de Gruyter, 1989.

FOSTER, P.; RAMASWANY, V.; ARTAXO, P.; BERNTSEN, T.; BETTS, R.; FAHEY, D. W.; HAYHOOD, J.; LEAN, J.; LOWE, D. C.; MYHRE, G.; NGANGA, J.; PRINN, R.; RAGA, G.; SCHULZ, M.; DORLAN. Changes in Atmosferic Constituints and in Radiative Forcing. IN: SOLOMON, S.; QIN, D.; MANNING, M.; CHEN, Z.; MARQUIS, M.; AVERYT, K. B.; TIGNOR, M.; MILleR, H. L., Eds. Climate Change 2007: The Physical Science Basis. Contribution of Working Group I to the Fourth Assessment Report of the Intergovernmental Panel on Climate Change. Cambridge, United Kingdom and New York, NY, USA, Cambridge University Press, p. 129-234, 2007

GONZÁleZ, G. Patologías Bióticas de la Madera: de los bosques templados de Chile, a la Selva Atlántica de Misiones. Universidad del Bio Bio-Concepcion-Chile. 2012.

HUECK, J.H. The biodeterioration of materials: an appraisal. International Biodeterioration \& Biodegradation, v. 48, pp. 5-11, 2001.

IPCC. Climate change 2007: Synthesis Report. 2007.

Disponível em: http://www.ipcc.ch/publications_and_data/ar4/syr/en/contents.html. Acessado em: 10/09/2011 
NAKICENOVIC, N. e SWART, R. Emissions Scenarios. Cambridge: Cambridge University Press, 2000.

IPCC Summary for Policymakers. In: STOCKER, T.F.; QIN, D.; PLATTNER, G.-K.; TIGNOR, M.; ALLEN, S.K.; BOSCHUNG, J.; NAUELS, A.; XIA, Y.; BEX, V.; MIDGLEY, P.M. (eds.) Climate Change 2013: The Physical Science Basis. Contribution of Working Group I to the Fifth Assessment Report of the Intergovernmental Panel on Climate Change. Cambridge, United Kingdom and New York, NY, USA: Cambridge University Press, 2013.

IRBE, I.; KARADELEV, M.; ANDERSONE, I.; ANDERSONS, B. Biodeterioration of external wooden structures Latvian cultural heritage. Journal of Cultural Heritage. v. 13s, p. 79-84, 2012

KÖPPER, W.; GEIGER, R. Klimate der Erde. Gotha: Verlag Justus Perthes. 1928.

KILPP, R. Desenvolvimento de modelos para previsão de temperatura em pavimentos flexíveis. RS. 2004. 86 f. Trabalho de conclusão de curso (Graduação em engenharia civíl) - Universidade Regional do Noroeste do Estado do Rio Grande do Sul Ijui, 2004

KIRK, T. K.; CONNORS. W. J.; ZEIKUS, J. G. Requirement for a Growth Substrate During Lignin Decomposition by Two Wood-Rotting Fungi. Appl. Environ. Microbiol. EUA, v. 32, n 1, p. 192-194, 1976.

KLOCK, U.; MUÑIZ, G. I. B.; HERNANDEZ, J. A.; ANDRADE, A. S. Química da madeira. 3 ed. CURITIBA: Universidade Federal do Paraná, Setor de Ciências Agrárias, Departamento de Engenharia e Tecnologia Florestal, 2005. 86 p.

LOBATO, M. Cidades mortas. São Paulo: Editora Globo, 2007. 192 p.

LOPÉS-MIRAS， M.M.; MARTÍN-SÁNCHEZ， I.; YEBRA RODRÍGUEZ， A.; ROMERO-NOGUERA， J.; BOLÍVAR GALIANO, F.; ETTENAUER, J.; 
STERFLINGER, K.; PIÑAR, G. Contribution of the Microbial Communities Detected on an Oil Painting on Cancas to its Biodeterioration. Plos one , v.8, n. 11, 2013.

MAIA, T.; HOLANDA, S. B. Vale do Paraíba: velhas fazendas. São Paulo: Companhia Editora Nacional, 1975. 119 p.

MAMBERTI, M. M. S. Planejamento regional do turismo no Vale do Paraíba: estudo de caso na micro-região de Bananal - SP. 2006. 127 f. Dissertação (Mestrado em Geografia) - Instituto de Geociências e Ciências Exatas, Universidade Estadual de São Paulo, Rio Claro, 2006.

MARINS, P. C. G. Trajetórias de preservação do patrimônio cultural paulista. IN: SETÚBAL, M. A. (Org.). Terra Paulista: trajetórias contemporâneas. São Paulo: Imesp: Cenpec , 2008. p. 237-267.

MARTIN, K. J., RYGIEWICZ. Fungal-specific PCR primers developed for analysis of the ITS region of environmental DNA extracts. BMC Microbiology. 2005

MILLIET, S. Roteiro do café e outros ensaios. $4^{\mathrm{a}}$ ed. São Paulo: Editora Hucitec, $1982,184 \mathrm{p}$.

MOHAMMADI, P.; KRUMBEIN, W. E. Biodeterioration of ancient stone materials from the Persepolis monuments (Iran). Aerobiologia, Oldenburg, v 24, p. 27-33, 2008.

MORAES, A. M. L; PAES, R. A. Introdução a Micologia IN: MOLINARO, E. M.; CAPUTO, L. F. G.; AMENDOEIRA, M. R. R. Conceitos e métodos para formação de profissionais em laboratório de saúde. v. 4, Rio de Janeiro: Amendoeira, 2009. p. 400- 495.

MOURA, C. A. Zoneamento geoambiental como subsídio à análise dos indicadores ambientais nas áreas de dutos: caracterização do clima como fator determinante da instabilidade das áreas de implantação de dutos. Instituto de Geociências e Ciências Exatas, Universidade Estadual de São Paulo, Rio Claro, 2006. 
NAKICENOVIC, N. e SWART, R. Emissions Scenarios. Cambridge: Cambridge University Press, 2000, 570 p.

OLIVEIRA, J. T. de. Histórias do Café no Brasil e no Mundo. Belo Horizonte, Rio de Janeiro: Editora Itatiaia Ltda, 1993, p. 247-8.

ORTIZ, R; PÁRRAGA, M. NAVARRETE, J.; CARRASCO, I.; DE LA VEGA, E.; ORTIZ, M.; HERRERA, P.; JURGENS,J.A; HELD, B.W.; BLANCHETE, R. A. Investigations of Biodeterioration by Fungi in Historic Wooden Churches of Chiloé, Chile. Microb Ecol, v. 67, pp.568-575, 2014

PACHAURI, R.; REISINGER, A. Climate change 2007: Synthesis Report. Contribution of working groups I, II and III to the fourth assessment report of the intergovernmental panel on climate change, Geneva: IPCC, pp. 104, 2007.

Disponível em: http://www.ipcc.ch/publications_and_data/ar4/syr/en/contents.html. Acessado em: 10/09/2011

PORNOU, A.; BOGOMOLOVA, E. Fungal colonization on excavated prehistoric wood: Implications for in-situ display. International Biodegradation \& Biodegradation. v. 63, p. 371-378, 2009.

PRADO JÚNIOR, C. História econômica do Brasil. 29. ed. São Paulo: Brasiliense, 1983. $364 \mathrm{p}$.

PUPIM, R. G. Cidade e território do oeste paulista: mobilidade e modernidade nos processos de construção e re-construção do urbano. 2008. 238 f. Dissertação (Mestrado em Arquitetura e Urbanismo) - Escola de Engenharia de São Carlos, Universidade de São Paulo, São Carlos, 2008.

RAMASWAMY, V.; BOUCHER, O.; HAIGH, J.; HAUGLUSTAINE, D.; HAYWOOD, J.; MYHRE, G.; NAKAJIMA, T.; SHI, G. Y.; SOLOMON, S. Radiative Forcing of Climate Change. IN: HOUGHTON, J.T., et. al., Eds. Climate Change 
2001: The Scientific Basis. Contribution of Working Group I to the Third Assessment Report of the Intergovernmental Panel on Climate Change. Cambridge, United Kingdom and New York, NY, USA: Cambridge University Press. p. 349-416, 2001 .

RIBEIRO, P. N. Técnicas construtivas nas alvenarias históricas, no Brasil. In BRAGA, M. B. (org.) Conservação e restauro: arquitetura brasileira. Rio de Janeiro: Ed. Rio, 2003. Cap. 3, p. 51-93.

ROJAS, T.I.; AIRA, M.J.; BATISTA, A.; CRUZ, I.L.; GONZÁLEZ, S. Fungal biodeterioration in historic buikdings of Havana (Cuba). Grana. v. 51, n. 1, p. 44-51, 2012.

SÁ Jr., A. Aplicação de Köppen para o zoneamento climático de Minas Gerais, Lavras, UFLA, 2009.

SABBIONI, C.; BRIMBLECOMBE, P.; CASSAR, M. The atlas of climate change: Impact on European Cultural Heritage. London: EU, 2007. 124 p.

TAUNAY, A. d'E. Notas sobre primórdios da lavoura cafeeira em S. Paulo. Revista do Instituto do Café. São Paulo, Ano X, no 96, janeiro de 1935, vol XIX, p 89.

TEATHER, R. M.; WOOD P. J. Use of Congo red-polysaccharide interactions in enumeration and characterization of cellulolytic bacteria from the bovine rumen. Appl. Environ. Microbiol. 43:777-780. 1982

TROIANO, F.; POLO, A.; VILLA, F.; CAPPITELLI, F. Assessing the microbiological risk to stored sixteenth century parchment manuscripts: a holistic approach based on molecular and molecular and environmental studies. Biofouling. v. 30, p.299-311, 2014.

UNITED NATIONS. United Nations Framework Convention on Climate Change. 1992. 
UNITED NATIONS EDUCATIONAL, SCIENTIFIC AND CULTURAL ORGANIZATION - UNESCO. World Heritage Centre. Predicting and managing the effects of climate change on world heritage. Vilnius, 2006.

VILES, H. A. \& CUTLER, N. J. Global environmental change and the biology of heritage structures. Global Chance Biology. v. 18, p. 2406 - 2418. 2012

WEBSTER, J \& WEBER, R. W. S. Introduction to Fungi. Cambridge, Cambridge University Press, 2007, 841 p.

WIEDENHOEFT, A. C.; MILLER, R. B. Structure and function of wood. In: ROWELL, R. M. (ed.). Handbook of wood chemistry and wood composites. New York: Taylor \& Francis Group, 2005, cap. 22. p. 18-42.

YOUNE, R. Y.; ROCHA, R. P. Clima presente e futuro do Vale Histórico Paulista 2013.

YOUNE, R. Y.; ROCHA, R. P. Clima presente e futuro do Vale Histórico Paulista 2014.

ZABEL, R. A. \& MORREL, J.J. Natural decay resistance. In: ZABEL, R. A.; MORRELL, J.J. Wood microbiology: decay and its prevention. San Diego: Academic Press, 1992. p. 399-411.

ZANIRATO. S. H. Experiências de prevenção de riscos ao patrimônio cultural da humanidade. Ambiente \& Sociedade. Campinas. v. XIII, n. 1, p. 151-164, jan.-jun. 2010. 